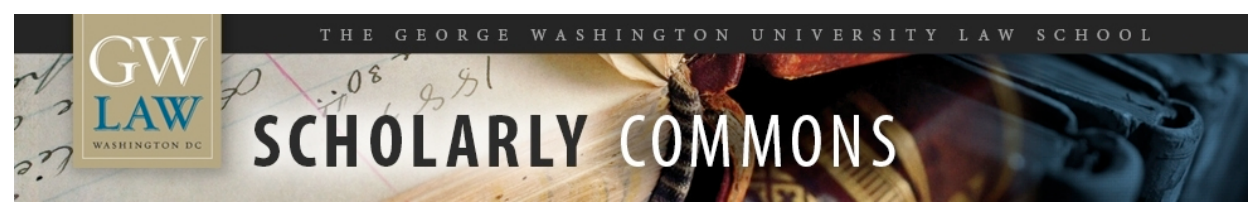

\title{
The Case Against Copyright: A Comparative Institutional Analysis of Intellectual Property Regimes
}

\author{
F. Scott Kieff \\ George Washington University Law School, skieff@law.gwu.edu
}

Follow this and additional works at: https://scholarship.law.gwu.edu/faculty_publications

Part of the Law Commons

\section{Recommended Citation}

Kieff, F. Scott, "The Case Against Copyright: A Comparative Institutional Analysis of Intellectual Property Regimes" (2004). GW Law Faculty Publications \& Other Works. 561.

https://scholarship.law.gwu.edu/faculty_publications/561

This Article is brought to you for free and open access by the Faculty Scholarship at Scholarly Commons. It has been accepted for inclusion in GW Law Faculty Publications \& Other Works by an authorized administrator of Scholarly Commons. For more information, please contact spagel@law.gwu.edu. 


\title{
(Working Draft)
}

\section{THE CASE AGAINST COPYRIGHT: A COMPARATIVE INSTITUTIONAL ANALYSIS OF INTELLECTUAL Property REGIMES}

\author{
F. Scott Kieff*
}

(C) 2004. F. Scott Kieff. All Rights Reserved.

\section{Abstract \\ Contemporary debates over intellectual property ("IP") generally} evidence positions that appear to line up at opposite ends of the same axis, with one side arguing for more rights for IP owners under each major regime - patent, trademark, and copyright - and the other side arguing for fewer. Approaching from what some may see as a "more" IP view, this paper offers the counterintuitive suggestion to consider abolishing one of these IP regimes copyright, at least with respect to the entertainment industry, which represents one of that regime's most commercially significant users. This realization is in fact consistent with the underlying view because the view is not accurately seen as even being directed to the "more" or "less" debate; and instead is focused on means as much as ends. In keeping with this means-directed approach, the paper provides the first comprehensive analysis of IP regimes using the set of tools from the field of new institutional economics. In so doing the paper offers the first normative case for IP that connects the path breaking literature on the theory of property rights generally with the seminal theories of the firm, transaction costs,

\footnotetext{
The author is Associate Professor and 2003-04 Israel Treiman Faculty Research Fellow at Washington University School of Law and 2003-04 \& 2004-05 W. Glenn Campbell \& Rita Ricardo-Campbell National Fellow and Robert Eckles Swain National Fellow at Stanford University's Hoover Institution; and, at the time this article was first drafted, he was 2001-02 \& 2002-03 John M. Olin Senior Research Fellow in Law, Economics, and Business at Harvard Law School. The author gratefully acknowledges financial support from the Progress \& Freedom Foundation, the John M. Olin Foundation, the Hoover Institution, and Washington University School of Law, as well as intellectual contributions from participants in the conferences "Promoting Markets in Creativity: Copyright in the Internet Age" held June 10, 2003 in Washington, D.C., jointly sponsored by the Progress \& Freedom Foundation and the Tech Center at George Mason University School of Law, and "Works-in-Progress in Intellectual Property Colloquium" held at Tulane University School of Law on October 17-18, 2003, and at Wolfson College, Cambridge University, June 28, 2004, in addition to more detailed comments provided by Michael Abramowicz, William Adkinson, Gregory Aharonian, Terry Anderson, Kenneth Arrow, John Barton, Ronald Coase, Richard Epstein, Milton Friedman, Wendy Gordon, Steve Haber, Paul Heald, Edmund Kitch, Bruce Kobayashi, Mark Lemley, Larry Lessig, Stanley Liebowitz, Glynn Lunney, Julia Mahoney, Charles McManis, Michael Meurer, Adam Mosoff, Tom Nachbar, Pauline Newman, Douglass North, Bruce Owen, Troy Paredes, Mitch Polinsky, Randall Rader, Steve Shavell, Henry Smith, Polk Wagner, and John Witherspoon. JEL Classifications: A12, B15, B25, D23, D29, D61, K11, K20, K29, K39, O31, O33, O34. Correspondence may be sent to fskieff.91@alum.mit.edu (permanent address).
} 
and agency costs. Underlying this paper's stark departure from both the "more" and "less" bodies of the IP literature is the realization that the institutional structure of the present copyright regime may make the social costs of the present copyright regime too high, for at least the entertainment industry, while at the same time preventing it from providing the coordination benefits an IP regime normatively should provide. Building on this, the paper begins to explore for the first time whether the recent patent and trademark regimes have institutional structures that may allow them to provide these coordination benefits better, and with lower social costs. The paper thereby suggests how the patent and trademark regimes of yesterday may obsolete the copyright system of today.

\section{Table of Contents}

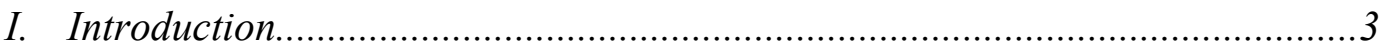

II. A Review of the Problems Explored through NIE ...........................................

A. Problems at the Individual Level ..............................................................12

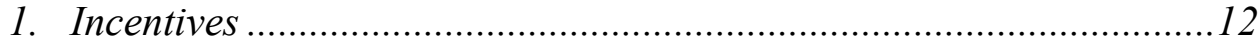

2. Rent Seeking and Rent Dissipation ............................................ 14

3. Information Costs .............................................................................16

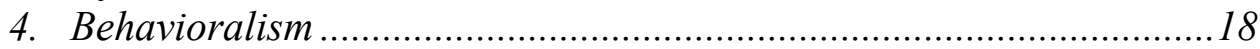

B. Problems at the Inter-Individual Level .................................................22

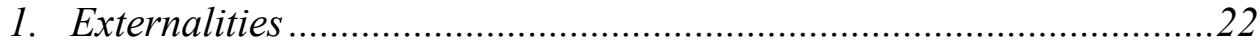

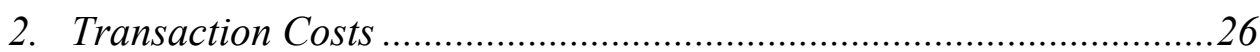

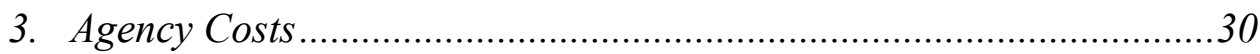

4. Coordination and Private Ordering ............................................ 33

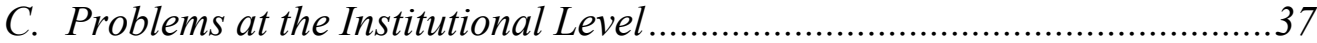

1. Laws, Norms, and Problems of Enforceability ....................................38

2. Markets and Market Failures ........................................................... 41

(a) Ex Ante vs. Ex Post and Dynamic vs. Static Efficiency ............. 42

(b) Monopoly Effects .................................................................. 45

3. Government, Government Failures, and Public Choice.....................47

4. Property Rights and Common Tragedies...........................................54

(a) Public Goods and Commons........................................................ 55

(b) Anticommons, Permit Thickets, and License Raj...................... 60

D. Wrapping-up Problems Explored through NIE ......................................64 64

III. Lessons from NIE for Law \& Economic Theories of IP .............................65

A. Problems of Reward Theories and the Incentive Access Paradigm ..........66

1. Imprudent Incentives..........................................................................6 68

2. Ineffective Access ......................................................................... 71

3. Allocation and Screening ................................................................. 76 
B. Problems of Prospect and Rent Dissipation Theories ........................... 78

1. Extent of the Rent Dissipation....................................................... 78

2. Effectiveness of the Tools for Mitigating Dissipation.......................81

C. Commercialization Theory, Coordination, and Social Costs ...................83

1. Overview of the Theory.............................................................. 84

2. Common Misperceptions on the Theory ..........................................86

3. Some Particularly Salient NIE Lessons on Social Costs for IP..........91

(a) Monopoly Effects .................................................................... 92

(b) Transaction Costs, Behavioralism, and Anticommons ................ 94

(c) Public Choice....................................................................... 100

IV. Implications from NIE for Comparing IP Regimes ................................... 103

A. The Basics of Positive Law IP Regimes...............................................105

B. Beginning the Case against Copyright ...............................................114

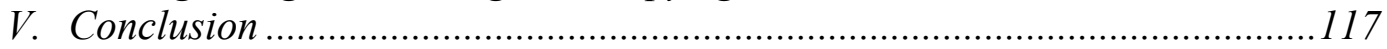

\section{INTRODUCTION}

This paper offers the first comprehensive analysis of IP theory and comparative outline of IP regimes using the set of analytical tools from the field called new institutional economics ("NIE"), which is often associated with the path-breaking work on institutions by Robert Fogel and Douglass North, for which they were awarded the 1993 Nobel Prize in economics, as well as the pathbreaking work on transaction costs, agency costs, and the theory of the firm by Ronald Coase, for which he was awarded the 1991 Nobel Prize in economics. ${ }^{1}$ In so doing, the paper offers the first theory of IP that connects the literatures on these seminal theories of the firm, agency costs, and information costs with the literature on the emergence of property rights generally. ${ }^{2}$

1 For more on the Nobel Prize to Fogel and North, see "The Bank of Sweden Prize in Economic Sciences in Memory of Alfred Nobel 1993," available on-line at http:/www.nobel.se/economics/laureates/1993/. For more on the Nobel Prize to Coase, see "The Bank of Sweden Prize in Economic Sciences in Memory of Alfred Nobel 1991," available on-line at http://www.nobel.se/economics/laureates/1991/. The term NIE, itself, was coined by Oliver Williamson, in OLIVER E. WILLIAMSON, MARKETS AND HIERARCHIES: ANALYSIS AND ANTITRUST IMPLICATIONS (1975) at 1, and the field of NIE owes a great deal to the path-breaking work of many important scholars in addition to Williamson, who elucidated the pervasive impact of transaction costs across a range of settings from markets and firms to other organizational structures and politics.

2 Although it is of course recognized that this paper will not be the only comprehensive treatment of IP theory from the perspective of NIE, and that the paper is not the first to explore IP implications of particular aspects of the NIE literature, the approach offered here is significantly more comprehensive than prior efforts. Indeed, the more comprehensive approach taken in this 
Many of the tools NIE uses to conduct comparative institutional analyses ${ }^{3}$ have played a central role in the scholarly debate within property theory about the shifts that occur over time among property regimes, generally. ${ }^{4}$ And there certainly have been many shifts in recent time that have occurred within the field of IP. ${ }^{5}$ Yet, the case for or against formal property rights for IP, in particular, has largely escaped the attention of the NIE literature, until the present endeavor. ${ }^{6}$

paper is particularly timely given the recent surge in interest in highlighting particular aspects of the interface between IP and NIE. See, e.g., Dan L. Burk, Intellectual Property and the Firm, 71 U. CHI. L. REV. 3 (2004) (exploring the importance of IP rights for firms), Mark Lemley, Ex Ante versus Ex Post Justifications for Intellectual Property, 71 U. CHI. L. REV. 129 (framing debate about IP rights in terms of timing); John F. Duffy, The Marginal Cost Controversy in Intellectual Property, 71 U. CHI. L. REV. 37 (2004) (exploring the problems associated with pricing above marginal cost for IP); Oren Bar-Gill \& Gideon Parchomovsky, Intellectual Property Law and the Boundaries of the Firm (Working paper, June 24, 2004) (available on-line at http://ssrn.com/abstract=559195) (connecting IP and the theory of the firm); Clarisa Long, Information Costs in Patent and Copyright, 90 Va. L. Rev. 4652004 (exploring information costs). Indeed, this paper can also be seen as building upon the important foundational essay by Robert Merges on the interface between NIE and IP. Robert P. Merges, Intellectual Property Rights and the New Institutional Economics, 53 VAND L. REV 1857 (2000) (seventeen-page essay elucidating some important lessons from NIE for IP but unlike the present effort not exploring in depth each of the problems studied by NIE and not connecting integrating them into an overarching theory of IP).

3 For a detailed discussion of these tools see infra Part II.

$4 \quad$ See, e.g., Symposium, The Evolution of Property Rights, 31 J. LEGAL STUD. S331 (2002) (including Thomas W. Merrill, Introduction: The Demsetz Thesis and the Evolution of Property Rights, at S331, Douglas W. Allen, The Rhino's Horn: Incomplete Property Rights and the Optimal Value of an Asset, at S339, Stuart Banner, Transitions between Property Regimes, at S359, Henry Hansmann \& Reinier Kraakman, Property, Contract, and Verification: The Numerus Clausus Problem and the Divisibility of Rights, at S373, Saul Levmore, Two Stories about the Evolution of Property Rights, at S421, Henry E. Smith, Exclusion versus Governance: Two Strategies for Delineating Property Rights, at S453, Terry L. Anderson \& Peter J. Hill, Cowboys and Contracts, at S489, Richard A. Epstein, The Allocation of the Commons: Parking on Public Roads, at S515, David D. Haddock \& Lynne Kiesling, The Black Death and Property Rights, at S545, Gary D. Libecap \& James L. Smith, The Economic Evolution of Petroleum Property Rights in the United States, at S589, Dean Lueck, The Extermination and Conservation of the American Bison, at S609, Harold Demsetz, Toward a Theory of Property Rights II: The Competition between Private and Collective Ownership, at S653).

5 See, e.g., Donald S. Chisum, Craig A. NArd, Herbert F. Schwartz, Pauline NeWman, AND F. SCOTT KIEFF, PRinciPles of PATENT LAW 6-42 (2 $^{\text {nd }}$ ed. 2001) (reviewing history of changes to patent law); Willaim F. PATRY, COPYRIGHT LAW AND PRACTICE 1-120 (1994) (reviewing history of changes to copyright law); ROBERT A. GORMAN \& JANE C. Ginsburg, Copyright 1-12 (6 ${ }^{\text {th }}$ ed. 2002) (same); Craig JoyCE, ET AL., Copyright LAW 15-27 $\left(6^{\text {th }}\right.$ ed. 2003) (same); BEVERLY W. PATTISHALl, ET AL., TRADEMARKS AND UNFAIR COMPETITION $1-5$ ( $4^{\text {th }}$ ed. 1998) (reviewing history of changes to trademark law); FRANK I SCHECTER, THE HiSTORICAL FOUNDATIONS OF TRADEMARK LAW (1925) (same).

6 To be sure, several important works explore the case for property rights in IP using approaches other than NIE. See, e.g., Margaret JAnE Radin, ReInVEnting Property (1993) 
Prior work by the present author has explored the comparative institutional economics of using property rights protected by property rules ${ }^{7}$ for patents and trademarks to facilitate the commercialization of inventions and embodiments of goodwill, respectively. ${ }^{8}$ This commercialization approach is (mistakenly) sometimes characterized as simply representing one of two sides within a larger debate over intellectual property in which views generally line up at opposite ends of the same axis, with one side arguing for more rights for IP owners under each major regime - patent, trademark, and copyright - and the other arguing for fewer. ${ }^{9}$

What is striking in view of this perception in the literature that the commercialization theory is a "more property" perspective is that when properly understood its NIE approach leads to the counterintuitive suggestion to consider abolishing one of these intellectual property regimes - copyright, at least with respect to the entertainment industry, which represents one of the most

(applying Hagel's personhood theory as an approach); Justin Hughes, The Philosophy of Intellectual Property, 77 GeO. L.J. 287 (1988) (reviewing philosophical approaches); Jeremy Waldron, From Authors to Copiers: Individual Rights and Social Values in Intellectual Property, 68 ChI. Kent L. Rev. 841, 866 (1993) (same); Abraham Bell \& Gideon Parchomovsky, What Property Is, University of Pennsylvania Institute for Law and Economics Research Paper No. 0405 (2004) (offering a "unified value" approach to property generally). In addition, as discussed more fully in part III, some more recent scholars have made important contributions by starting to focus on particular components of the NIE literature, such as information costs, interactions with a firm, and marginal cost pricing, and some aspects of the distinction between ex ante and ex post. But as also discussed more fully in Part III, none of these projects embraces the set of tools from the field of NIE.

7 The label "property rule" is used here as it is used in the classic Calabresi-Melamed framework under which an entitlement is said to enjoy the protection of a property rule if the law condones its surrender only through voluntary exchange. The holder of such an entitlement is allowed to enjoin infringement. An entitlement is said to have the lesser protection of a liability rule if it can be lost lawfully to anyone willing to pay some court-determined compensation. The holder of such an entitlement is only entitled to damages caused by infringement. See Guido Calabresi \& A. Douglas Melamed, Property Rules, Liability Rules, and Inalienability: One View of the Cathedral, 85 Harv. L. Rev. 1089 (1972). But see, Jules L. Coleman \& Jody Kraus, Rethinking the Theory of Legal Rights, 95 YALE. L.J. 1335 (1986) (offering a "reinterpretation of the Calabresi-Melamed framework" under which property rules and liability rules merely represent two pieces of a broader "transaction structure" in that they are two different approaches for setting forth "conditions of legitimate transfer").

8 See F. Scott Kieff, Property Rights and Property Rules for Commercializing Inventions, 85 MinN. L. REV. 697 (2001) (comparative institutional analysis of patent-enforcing rules) [hereinafter "Kieff, Commercializing Inventions"]; F. Scott Kieff, The Case for Registering Patents and the Law and Economics of Present Patent-Obtaining Rules, 45 B.C. L.REV. 55 (2003) (comparative institutional analysis of patent-obtaining rules) [hereinafter, "Kieff, Registering Patents"].

9 See, e.g., R. Polk Wagner, Reconsidering Estoppel: Patent Administration and the Failure of Festo, 151 U. PA. L. REV. 159, 163, n.10 (2002) (collecting sources on "the larger debate about patent scope"). 
commercially significant bodies of copyrighted works. ${ }^{10}$ This suggestion is in fact consistent with the underlying view because the view is not accurately seen as being even directed to the "more" or "less" debate; and instead is focused on means as much as ends. That is, the question explored here is not merely whether any particular IP regime should give more or less protection; but rather how well the regime operates to achieve its desired goals and what those goals are in the first place. As explained more below, underlying this paper's stark departure from both the "more" and "less" bodies of the IP literature is the realization that aspects of the institutional structure of the present copyright regime makes the social costs of the present copyright regime too high, for at least the entertainment industry, while at the same time preventing it from providing the coordination benefits an IP regime normatively should provide. In contrast, the institutional frameworks recently used for the patent and trademark regimes may allow them to better provide these coordination benefits, and with lower social costs. The paper thereby opens the door to the exploration of a new industrial organization model for the entertainment industry under which the patent and trademark regimes of yesterday may obsolete the copyright system of today.

This paper also stands in sharp contrast to prior efforts to re-evaluate the case for IP from first principles. For example, the leading work by Stephen Breyer, which despite having spawned much of the recent literature on the weak property side of the debate, reaches a decidedly ambivalent position: " $[\mathrm{H}] \mathrm{e}$ is unable to conclude that copyright should be abolished, but he argues that its extension is unnecessary and would be harmful."11 Similarly, the most recent work on copyright by Richard Epstein, which was presented at the same conference as this paper, generally supports the present institutional framework of copyright law and concludes that when balancing the costs of exclusion versus governance "we could conclude that a sensible system of copyright is not such a bad trade-off after all." 12 In contrast with those efforts, the comparative

10 To some extent, the use here of the term "property" is somewhat imprecise, which is good in providing a short hand introduction to help frame the central theme of the paper, and bad in failing, like all short hand expressions, to capture the full complexity of the situation. The approach in this paper may be fairly characterized as an effort to show how using the taxonomy of property provided by Henry Smith, patent and trademark function more like exclusion forms of property while copyright functions more like a governance form, but all three might be seen as property. See, Henry E. Smith, Exclusion versus Governance: Two Strategies for Delineating Property Rights, 31 J. LEGAL StUd. S453 (2002). See also Adam Mossoff, What is Property? Putting the Pieces Back Together, 45 ARIzONA L. REV. 371 (2003) (reviewing theories of property).

${ }_{11}$ Stephen Breyer, The Uneasy Case for Copyright: A Study of Copyright in Books, Photocopies, and Computer Programs, 84 HARV. L. REV. 281 (1970).

12 Richard Epstein, Cracks in the Foundation of Copyright, University of Chicago Law School John M. Olin Law \& Economics Working Paper No. 204 (2d Series), at 40 (citing Richard 
institutional analysis of this paper reveals how while the patent and trademark regimes basically work well in general, the copyright system on balance does not. Particularly in light of new technologies, the marginal benefits of the copyright regime may be too small to justify its use given the availability of patent and trademark regimes, while at the same time the costs of the copyright regime may be too great.

Perhaps more importantly, this paper elucidates why this seemingly radical suggestion makes sense by elucidating the important lessons from the field of NIE that can be used to best shape the institutional framework for any IP regime. That is, the paper offers a comprehensive theory of IP using the set of tools from NIE. Put simply here for introductory purposes, ${ }^{13}$ the paper elucidates a goal IP can achieve effectively and efficiently. Through a survey of the NIE literature, the paper shows that while IP regimes should not be expected to be effective in achieving a reward function or in providing direct incentives for specific inventive or creative efforts, they should be expected to be effective in facilitating coordination among complementary users of the subject matter protected by the regime. But to achieve this goal efficiently they must be designed to mitigate various social costs including transaction costs, coordination costs, and public choice costs. Taking these lessons, the paper then outlines the general nature of the economic costs and benefits of the particular features that distinguish the relative performance of the different institutional approaches offered by the IP regimes of patent, trademark, and copyright.

In brief, concerning benefits, the commercialization costs associated with major copyright-based industries today, such as publishing, film, and television, are largely those associated with reputation and business networks (because of technological change other commercialization costs for these industries are less). Trademark law works well to allow some coordination and some pricing above marginal cost of the type necessary to facilitate commercialization of goods and services facing such reputation and network costs. Indeed, if the result in the recent Dastar decision had not occurred or were statutorily reversed, even copying by competitors could be prevented through actions for false advertising. ${ }^{14}$ And major advances in these industries, although likely rare, are eligible for patent protection (a new projector, a new chord, etc). ${ }^{15}$ Thus, patents and

A. Epstein, Let "The Fundamental Things Apply:" Necessary and Contingent Truths in Legal Scholarship, 115 HARV. L. REV. 1288 (2002)).

13 For more on the lessons of NIE for IP see infra Part III.

14 See F. Scott Kieff, Contrived Conflicts: The Supreme Court vs. The Basics of Intellectual Property Law, 30 William Mitchell L. Rev. 1717, 1722-26 (2004) (discussing Dastar Corp. v. Twentieth Century Fox Film, 539 U.S. 23, 123 S.Ct. 2041 (2003) (holding Lanham Act does not prevent unaccredited copying of uncopyrighted work)).

15 See CHISUM, ET AL. supra note 5, at 728-828 (discussing statutory subject matter). 
trademarks may provide effectively the coordination benefits needed by these industries. $^{16}$

Concerning costs, the present copyright system is so complex and so rapidly changing that it simply fails to facilitate the private ordering that IP regimes can and should deliver. The copyright statute is essentially a set of large collective bargaining agreements struck through a discourse focused on metering out an amount of reward as a direct incentive for particular creative efforts that is "just right," and that as a result probably work for the groups who negotiated them based on the needs of those groups at that time but they do not easily fit new technologies and markets, let alone the needs of all those players who were not at that table at the time of the negotiations. At bottom, the costs associated with the system - such as for example transaction costs, coordination costs, and public choice costs - are simply too large, and are an affront to private ordering. ${ }^{17}$

Put simply, the complexity of modern copyright may prevent the system from achieving the coordination benefits IP rights can deliver, which patents and trademarks generally do deliver. In addition, the same complexity of modern copyright causes the costs of the system to be remarkably high. One conclusion is that the case today for copyright itself may simply fail. Put differently, the insight explored in this paper shows that the best way for copyright to become even more obsolete in view of patent and trademark is for copyright to become even more complex than it already is.

In either case, the paper opens the door to the study of a new industrial organization model for the entertainment industry based on patent and trademark, rather than copyright. Far from offering the final word on this model, the paper elucidates why it might be rational for individuals in the entertainment industry to consider using it individually (which some implicitly may have begun to do already), and for policy makers to consider encouraging its use more broadly.

This paper proceeds in Part II to review the core analytical tools and lessons of NIE. Part III applies these tools to study the normative law and economic case for the positive law IP regimes, in general. Part IV outlines a comparative analysis among the institutions of the patent, trademark, and copyright regimes and begins to ask whether a sketch of a new industrial organization model for the entertainment system could operate using patents and trademarks instead of copyrights, while exploring some likely objections to the model and suggesting areas of future research. Part V concludes.

\footnotetext{
16 This is so even though the subject matter that is protected by each regime is different.

17 For more on the social costs of copyright see infra Part IV.A. For more on what is meant by the term "private ordering" as used here see infra note 163.
} 


\section{A REVIEW OF THE Problems ExPlored through NIE}

The field of NIE pays particular attention to the economic significance of institutions, as distinct from other factors, such as technology, capital, or labor. ${ }^{18}$ As described in North's Nobel Essay:

Institutions are the humanly devised constraints that structure human interaction.

They are made up of formal constraints (rules, laws, constitutions), informal constraints (norms of behavior, conventions, and self imposed codes of conduct), and their enforcement characteristics. ${ }^{19}$

NIE emphasizes the use of comparative institutional analyses to look at the different characteristics of institutions and what impact they have on individuals and organizations over time. ${ }^{20}$ The comparative institutional analysis approach of NIE teaches us to ask not only what we want, but also which mix of formal and informal institutions will work better in achieving our set of goals.

The approach makes both conceptual and practical sense. Engaging in a comparative institutional analysis makes conceptual sense because the perfect institution, like the perfect anything, simply is not achievable. Every real institution will have some problems. For this reason, institutional choices should not be about a singular search for perfection but rather about which sets of problems and benefits are best suited to tolerances and needs. Put differently, it is better to compare the particular costs and benefits of actually available options than merely to identify problems with any one option and seek to perfect it. This

18 For a good introduction to NIE, see JOHN DROBAK \& JOHN NYE, FrONTIERS OF THE NEW INSTITUTIONAL ECONOMICS (1997) (volume of papers honoring Douglass North and his contribution to the field of NIE). See also THRAINN EGGERTSSON, ECONOMIC BEHAVIOR AND INSTITUTIONS (1990) (survey of NIE, or as Eggertsson refers to it: "neo-institutional economics"); Philip Keefer \& Mary M. Shirley, Formal versus Informal Institutions in Economic Development, in Claude Menard, Institutions, Contracts, and Organizations: Perspectives from NeW INSTITUTIONAL ECONOMICS (2000) (collecting sources).

19 Douglass C. North, Prize Lecture, available on-line at http://www.nobel.se/economics/laureates/1993//north-lecture.html. As Coase points out, the field of NIE differs from the older field known as "institutional economics" because NIE does more than merely highlight the economic impact of institutions as compared with capital, labor, and technology. NIE also develops a research agenda devoted to characterizing this impact. That is, NIE does not just note that institutions matter, or that law matters, NIE endeavors to elucidate how institutions matter. See Ronald Coase, The New Institutional Economics, 88 AM. ECON. REV. 72 (1998).

20 For detailed explorations of NIE, see EIRIK G. FURUBOTN \& RUDOLF RICHTER, INSTITUTIONS AND ECONOMIC THEORY: THE CONTRIBUTION OF THE NEW INSTITUTIONAL ECONOMICS (2003) (reviewing field and collecting sources) and MASAHIKO AOKI, TOWARDS A COMPARATIVE INSTITUTIONAL ANALYSIS (2001) (applying game theory to comparative institutional analysis and NIE). 
is a theory of the "second-best." ${ }^{21}$ The search for perfection is what Demsetz calls the "nirvana" fallacy; ${ }^{22}$ and as Voltaire noted, it is through such searches that "the perfect is the enemy of the good." 23

To be sure, this is not to say that any particular institution, existing or otherwise, should not be studied critically or that everything should be left alone. Such complacency ignores the countervailing sage warning by John Dewey that "the better is too often the enemy of the still better." 24

At bottom, a core lesson of NIE is that even when there is consensus about what the goals of a particular institution should be, the particular choices that are made about the details of the institutional framework will have different important implications for a number of problems operating on a number of levels. ${ }^{25}$ On the individual level, these problems include, inter alia, those of incentives, rent dissipation, information costs, and behavioralism. ${ }^{26}$ On the interpersonal level, these problems include, inter alia, those of transaction costs, agency costs, and coordination and private ordering. ${ }^{27}$ On the institutional level, these problems include, inter alia, enforceability of laws and norms, market failures, the differences between dynamic and static efficiency or between ex ante and ex post considerations, monopoly effects, government failures and public choice, as well as public goods problems and the tragedies of the commons and anticommons. ${ }^{28}$

21 See, e.g., Peter J. Hammer, Antitrust Beyond Competition: Market Failures, Total Welfare, and the Challenge of Intramarket Second-Best Tradeoffs, 98 MicH. L. REV. 849 (2000) (applying second-best analysis in antitrust context); Richard S. Markovits, Monopolistic Competition, Second Best, and the Antitrust Paradox: A Review Article, 77 MicH. L. REV. 567 (1979) (same); Richard S. Markovits, Second-Best Theory and Law \& Economics: An Introduction, 73 CHI.-KENT. L. REV. 3 (1998) (overview of second best theory); Andrew P. Morriss, Implications of Second-Best Theory for Administrative and Regulatory Law: A Case Study of Public Utility Regulation, 73 CHI.-KENT L. REV. 135, 170-76 (1998) (application to administrative law); Oliver E. Williamson, Economies as an Antitrust Defense: The Welfare Tradeoffs, 58 AM. ECON. REV. 18 (1968) (example of early path-breaking work using second-best approach); Oliver E. Williamson, Economies as an Antitrust Defense Revisited, 125 U. PA. L. REV. 699 (1977) (same).

22 Harold Demsetz, Information and Efficiency: Another Viewpoint, 12 J.L. \& ECON. 1, 1 (1969) (critiquing the so-called nirvana approach in favor of a comparative institution approach).

23 Voltaire, Dictionnaire Philosophique ("le mieux est l'ennemi de bien:" literally, "the best is the enemy of the good," or colloquially, "the perfect is the enemy of the good").

24 Cass R. Sunstein, Free Speech Now, 59 U. CHI. L. REV. 255, 315 (1992) (citing John J. McDermott, ed, The Philosophy of John Dewey 652 (Chicago, 1973)) ("To the economists' plea that 'the perfect is the enemy of the good,' we might oppose Dewey's suggestion that 'the better is too often the enemy of the still better."').

25 For a somewhat more detailed discussion of each of these problems see infra Part II.

26 See infra Part II.A.

27 See infra Part II.B.

28 See infra Part II.C. 
Because different institutional choices will have different implications positive and negative - for these different problems, NIE teaches why it makes sense as a conceptual matter to pay attention to means as well as ends. ${ }^{29}$ What is more, because institutions are essentially endogenous - we can change them if we want $^{30}$ - a comparative institutional analysis makes great sense as a practical matter as well. ${ }^{31}$

To be sure, each of the problems considered in association with NIE is the subject of its own debates and sub-fields within the law, economics, and political science literatures; and therefore a full discussion of each is beyond the scope of this article. $^{32}$ Nevertheless, because each refers to phenomena that may be understood by a general audience, it is discussed more fully below to provide at least some introduction to its relevance to the debates over IP in particular. In addition, while the below discussions of these problems are grouped for presentation purposes by the level at which they are most evident, and with the recognition that in some respect these groupings are inevitably imperfect, most of these problems can be seen to operate on more than one level.

29 For a short and accessible overview of these various problems in the context of NIE see Oliver E. Williamson, The Institutions of Governance, 88 AM. ECON. REV. 75 (1998) (collecting sources)). See also Oliver E. Williamson, The New Institutional Economics: Taking Stock, Looking Ahead, 38 J. ECON. LITERATURE, 595 (2000) (same).

30 The term "we" is used here in its broadest sense to refer to people, in general. Often, even groups of people are unable effectively to have particular government agencies or other institutions fully incorporate their views. Indeed, this is one of the problems explored in NIE under the topic of "public choice." For more on public choice, see infra Part II.C.3.

31 To be sure, some institutions are harder to change than others. For example, re-writing statutes may not change the behavior of courts, and may also not have the desired effect on norms. In the end, the mix of institutions that may be best may depend in part on the institutions that are presently at play. Put differently, path dependency may also be relevant to the comparative institutional analysis. In addition, the field of NIE extends far into the realm of political science, where the process of institutional change is well studied.

32 Indeed, debate continues over even the field of NIE itself, and in particular its relation to other fields such as "Law and Economics," and "neoclassical economics." For a collection of views on the debate over the proper characterization of the field of NIE in relation to the disciplines of economics and law, including debates over the particular problems explored by NIE, see, generally, Richard A. Posner, The New Institutional Economics Meets Law and Economics, 149 J. Institutional \& TheOreticAl ECON., 73 (1993)[hereinafter Posner, NIE Meets L\&E]; Oliver E. Williamson, Transaction Costs Economics Meets Posnerian Law and Economics, $149 \mathrm{~J}$. Institutional \& TheORETiCAl ECON., (1993); Ronald H. Coase, Coase on Posner on Coase, 149 J. Institutional \& TheOREticAl ECON., 96 (1993); Richard A. Posner, Reply, 149 J. InSTITUTIONAL \& THEORETICAL ECON., 119 (1993). This paper is agnostic about these debates and indeed takes as positive the contributions of the many important scholars whose work serves as the basis on which the field, by any name, has been built, while endeavoring to highlight each of the important themes that have emerged from these debates in the subsections that follow. 


\section{A. Problems at the Individual Level}

Several of the problems explored by NIE are most evident when considering actions or decisions at the level of the individual. ${ }^{33}$ These include, inter alia, the problems of incentives, rent seeking, information costs, and behavioralism. Importantly, one of the essential insights that can be taken from the field of NIE is that these problems are not unique to individuals acting in markets, and indeed also extend to individuals acting in hierarchies, such as firms or governments. ${ }^{34}$ That is, these are problems shared by all individuals, private and public.

\section{Incentives}

A basic and consensus lesson of economics is that because individuals ${ }^{35}$ have complex agendas, or preferences, and only limited resources available to be deployed to achieve the diverse items on these agendas, they must, and do, make choices about which agenda items to pursue before others. The point here is not that people are perfectly rational in making such choices; but only that they must, and do, indeed make such choices, at least implicitly. ${ }^{36}$ To be sure, as explored by Gary Becker in the path-breaking work extending economic analysis to new areas of human behavior and relations for which he was awarded the 1992 Nobel Prize in Economics, "no approach of comparable generality has yet been

33 The term "individual" is used here in its broad sense to refer to an entity that is acting as an individual, thereby including not only a single person, but also a group of people when acting as a group, such as a firm or government agency.

34 Leading scholars who have studied these effects in what many might view as the private sector - studying interactions within and among firms and in other financial or business settings include Ronald Coase and Oliver Williamson. Leading scholars who have studied these effects in what many might view as the public sector - studying interactions between voters and elected officials, within and among government agencies, and in other political settings - include James Buchanan, Randy Calvert, Douglass North, and Barry Weingast. Many leading scholars made path-breaking contributions to both sides, including Kenneth Arrow (information, regulation) Milton Friedman (regulation, price), and George Stigler (economics of information and economics of regulation). For an excellent bibliography on NIE see, FURUBOTN \& RICHTER, supra note 20, at 497-538.

35 For the broad definition of individual used herein see supra note 33.

36 See generally, Russell B. Korobkin \& Thomas S. Ulen, Law and Behavioral Science: Removing the Rationality Assumption from Law and Economics, 88 CAL. L. REV. 1051 (2000) (reviewing limits of rational choice theory).

37 See, Press Release: The Sveriges Riksbank (Bank of Sweden) Prize in Economic Sciences in Memory of Alfred Nobel for 1992, available on line at http://www.nobel.se/economics/laureates/1992/press.html. 
developed that offers serious competition to rational choice theory."38 Yet, the point here is not to take sides in the debate about whether rational choice theory fully captures the behavioralism models or whether they are appropriately considered somehow distinct. ${ }^{39}$ Instead, the point is simply to note that consideration of incentives, agendas, and resources does make sense because people themselves really do consider them, as Becker noted when borrowing an aphorism from fellow Nobel Laureate George Bernard Shaw about the general tendency individuals have to try to make the most out of their lives: "[e]conomy is the art of making the most of life."

An important implication of incentive analysis is that a given individual's agenda is likely to be complex, and for example might include the goals of accruing money, fame, relaxation, or other things. Such an individual will regularly make decisions that effectively set priorities among these different goals. As some items on the agenda appear to that individual to be less likely to be achieved, the individual will tend to shift focus, or re-prioritize, towards other items on the agenda. For example, if it appears harder to obtain some hypothetical goal A than some other hypothetical goal B, then investment in achieving A relative to $\mathrm{B}$ will decrease. The complex interaction among agendas, resources, information, and decision-making helps explain why actual incentive effects may be different than hypothesized. The true set of relevant parameters may not have been accurately perceived, may have changed, or both.

Even when a particular incentive effect is accurately predicted, the exact outcome it induces may be different than expected because of the many of the other problems discussed below. In addition, one problem associated with incentives getting too strong, which therefore may be thought of essentially as a side effect, is the problem of rent seeking, or rent dissipation, as discussed below.

The essential lesson when considering incentives for purposes of this discussion is that the mere identification of a potential incentive effect does not indicate a great deal about its net impact in a real-world situation. Important implications of this lesson will be discussed below in the context of agency costs, ${ }^{41}$ coordination and private ordering, ${ }^{42}$ public and private institutions, ${ }^{43}$ and IP theory. 44

38 Gary S. Becker, Nobel Lecture: The Economic Way of Looking at Behavior, in THE EsSENCE OF BECKER, 633, 650 (Ramon Febero \& Pedro Schwartz, eds. 1995).

39 For more on behavioralism limitations to rationality see infra Part II.A.4.

40 See Press Release supra note 37 (citing Becker quoting Shaw). See also, Gary S. Becker, The Economic Approach to Human Behavior, in THE ESSENCE OF BECKER, supra note 38, at 3 (Becker quoting Shaw).
41 See infra Part II.B.3.
42 See infra Part II.B.4.
43 See infra Part II.C.
44 See infra Part III. 


\section{Rent Seeking and Rent Dissipation}

Rent is the benefit that is gained by engaging in a certain activity. Private rents are those accruing to the individual. Public rents are those accruing to society as a whole.

One problem associated with rents is that private and public rents may be different. For example, what an inventor gets for herself often is less than what her invention generates for society. ${ }^{45}$ The potential differences in both magnitude and sign between public and private rents can lead to private incentives to engage in a given rent-generating activity to be either too little or too big than would be socially optimal. As another example, an inventor may develop something only slightly better than available options in a way that turns out to cause waste overall. ${ }^{46}$ Because this particular problem of rents also can be thought of as the problem of externalities, it is discussed in more detail in the section on externalities below. ${ }^{47}$

A related problem associated with rents is that they may provide incentives for an individual to engage in efforts designed to gain private rents but that may turn out ultimately to dissipate social rents. This is the problem of rent dissipation. Rent dissipation itself can take at least two forms. One type of rent dissipation involves over investment in the race to obtain the rent. Another type of rent dissipation involves investment in alternative but socially undesirable techniques to win that race.

The most common way to conceptualize the over investment type of rent dissipation is in the context of a race towards a common prize. If the community is characterized by a prize having a known value and an uncoordinated group of individuals who are each seeking the prize, then each individual might rationally elect to spend up to just less than the value of the prize to get it, which would mean that as a group they are spending more in aggregate than the value of the prize. $^{48}$ In the context of innovation, the effect has been demonstrated by

45 See Steven Shavell and TANGuy van YPersele, ReWARds Versus InTellectual PROPERTY RIGHTS (National Bureau of Econ. Research Working Paper No. 6956, 1999) (suggesting a system of government-sponsored cash rewards instead of or in addition to a system of patents as a tool for improving the match between the private and public rents associated with an invention).

46 A.K. Dixit \& Joseph E. Stiglitz, Monopolistic Competition and Optimum Product Diversity, 67 AM. ECON. REV. 297 (1977) (showing how it may be profitable for the one firm to come to market to get the customers but yet total industry profits can decline by more than consumer welfare increases).

47 For a discussion of externalities, see infra Part II.B.1.

48 If the value of the prize is $\mathrm{X}$ and the group of individuals is $\mathrm{Y}$ in number then each individual might rationally elect to spend up to just less than $X$ to obtain the prize, say some amount equal to $\mathrm{X}$ minus a small discount, say $\varepsilon$ or $(\mathrm{X}-\varepsilon)$. Yet, if all individuals spend that amount, then the community has spent the amount equal to $[(\mathrm{X}-\varepsilon) \mathrm{x} \mathrm{Y}]$ to obtain something worth 
economic models of multiple firms seeking the same invention in a race to patent, which show that investment overall may be too great. ${ }^{49}$ Nevertheless, this type of rent dissipation may be less of a problem in reality than in theory for a number of reasons, especially when it comes to the subject matter covered by IP, as discussed in more detail in the discussion of the prospect and rent dissipation theories of IP. ${ }^{50}$

The most common way to conceptualize the improper alternative investment type of rent dissipation is also in the context of a race towards a common prize, but this time where some types of racing are viewed by society as good (or fair) and others are viewed as bad (or unfair). In the context of sports, for example, the use of practice sessions is often viewed as good while the use of performance-enhancing drugs is often viewed as bad. In the context of regulated markets, the use of innovation is generally considered to be a good form of competition (making better products or services) while the use of agency capture is generally considered to be a bad form of competition (getting the government to differentially regulate a competitor). Because this type of rent dissipation can also be thought of as the problem of public choice, it is discussed in more detail in the section on public choice below. ${ }^{51}$

A central lesson to be taken from the NIE literature on rent dissipation for purposes of this discussion is that rent dissipation is a problem that must be considered when shaping institutions like IP. Different institutional frameworks can have different implications for rent dissipation. As discussed in more depth below within the context of IP theory, concerns about rent dissipation can be addressed by a properly shaped IP regime; but concerns about rent dissipation can not totally drive the shaping of such a regime. ${ }^{52}$

only $\mathrm{X}$. The rub is that the expression $[(\mathrm{X}-\varepsilon) \mathrm{x} \mathrm{Y}]$ will be greater than $\mathrm{X}$ itself as long as $\mathrm{X}$ and $\mathrm{Y}$ are positive numbers greater than one and $\varepsilon$ is a positive number less than one. Put simply, the amount spent in that community as a whole to obtain the prize is greater than the amount the community as a whole got by obtaining the prize, which would be a waste of resources.

49 See, e.g., Glenn C. Loury, Market Structure and Innovation, 93 Q. J. ECON. 395 (1979) (model showing overinvestment under appropriate conditions). P. Dasgupta \& Joseph E. Stiglitz, Industrial Structure and the Nature of Innovative Activity, 90 ECON. J. 266 (1980) (same).

50 For a discussion of these theories, see infra Part III.B.

51 For a discussion of public choice, see infra Part II.C.3.

52 See infra Part III (discussing limits of the so-called rent dissipation theories of IP but pointing out how properly shaped IP regimes can nevertheless mitigate rent dissipation effects). 


\section{Information Costs}

There are a number of significant problems associated with information and these are generally referred to collectively as information costs. ${ }^{53}$ In order for individuals to even make the many decisions associated with acting through either the market or political processes, they must be able to obtain and use information appropriately. The importance of considering the difficulties in obtaining and using information when studying decision-making was elucidated in the pathbreaking work by Herbert Simon, for which he was awarded the Nobel Prize in economics in $1978 .^{54}$

The problems of finding information in the first place - often called search costs - were elucidated in the path-breaking work by George Stigler, ${ }^{55}$ which formed part of the foundation for which he was awarded the Nobel Prize in economics in $1982 .^{56}$ In the same work, Stigler elucidated various tools for decreasing search costs, including, reputation and advertising. ${ }^{57}$ Stigler also elucidated the problem of using information in his work on statistical inference. ${ }^{58}$

As nicely summarized by Oliver Williamson, four other distinct problems associated with information were elucidated in the path breaking works by Kenneth Arrow, some of which formed part of the foundation for which he shared the Nobel Prize in economics in $1972:^{.5}$

The ways in which information influences economic organization include (1) the

"fundamental paradox" of information: "its value for the purchaser is not known

53 For an excellent survey of information and uncertainty see Jack Hirshleifer \& John G. Riley, The Analytics of Uncertainty and Information-An Expository Survey, 17 J. ECON. LIT. 1375, 1404 (1979) (collecting sources).

54 See, e.g., Herbert A. Simon, A Behavioral Model of Rational Choice, Q. J. ECON., at 241 (1955) ("the task is to replace the global rationality of economic man with a kind of rational behavior that is compatible with the access to information and computational capacities that are actually possessed by ... man."). See also, Press Release: The Sveriges Riksbank (Bank of Sweden) Prize in Economic Sciences in Memory of Alfred Nobel for 1978 (available on-line at http://www.nobel.se/economics/laureates/1978/press.html).

55 See, e.g., George J. Stigler, The Economics of Information, 69 J. PoL. ECON. 213 (1961) (elucidating the importance of information search costs and various methods for decreasing them including, for example, reputation and advertising).

56 See, Press Release: The Sveriges Riksbank (Bank of Sweden) Prize in Economic Sciences in Memory of Alfred Nobel for 1982 (available on-line at http://www.nobel.se/economics/laureates/1982/press.html.

$57 \quad$ See Stigler supra note 56.

58 See, e.g., George J. Stigler, A Theory of Oligopoly, 22, J. Pol. EcON. 44 (1964) (using statistical inference techniques to examine oligopoly).

59 See Press Release: The Sveriges Riksbank (Bank of Sweden) Prize in Economic Sciences in Memory of Alfred Nobel for 1972 (available on-line at http://www.nobel.se/economics/laureates/1972/press.html) (noting Arrow's work on “decision theory"). 
until he has the information, but then he has in effect acquired it without cost;" (Arrow [1971, 152]); (2) information asymmetry: "the critical impact of information on the optimal allocation of risk bearing is not merely its presence or absence but its inequality among economic agents" (Arrow [1969, 55]); (3) appropriability: "It really calls for some explanation, why the firm that has developed the knowledge cannot demand a greater share of the resulting profits" (Arrow [1962, 355]; and (4) the distinction between hidden action and hidden information problems (moral hazard and adverse selection, respectively) (Arrow $[1985,38-48])^{60}$

The problem of the information paradox reveals important reasons why it can be difficult for parties to negotiate over information itself and so is discussed more fully below in the section on public goods. ${ }^{61}$ The problem of information asymmetry reveals important reasons why it can be difficult for parties to negotiate over many types of goods and services. As elucidated in the path breaking work on information asymmetry for which George Akerlof, Michael Spence, and Joseph Stiglitz shared the 2001 Nobel Prize in Economics, ${ }^{62}$ the information asymmetry problem includes the problem of adverse selection, ${ }^{63}$ yet there are tools available for mitigating this problem including signaling ${ }^{64}$ and screening. ${ }^{65}$ Each of these problems is also closely related to the problems

60 Williamson supra note 32, at 112 (citing KENNETH ARROW, ESSAYS IN THE THEORY OF RISK-BEARING, at 152 (1971); Kenneth Arrow, The Organization of Economic Activity: Issues Pertinent to the Choice of Market Versus Nonmarket Allocation, in Joint Econ. Comm., 91st Cong., The Analysis and Evaluation of Public Expenditures: The PPB System 47-64, at 55 (Comm. Print 1969) [hereinafter "Arrow, The Organization of Economic Activity"]; Kenneth Arrow, Comments on Case Studies, and Economic Welfare and the Allocation of Resources of Invention, in THE RATE AND DIRECTION OF INVENTIVE ACTIVITY II: ECONOMIC AND SOCIAL FACTORS (Nat'l Bureau Comm. for Econ. Res. eds., 1962) 355, 609; Kenneth Arrow, The Economics of Agency, in JOHN PRATT \& RichARD ZECKHAUSER, PRINCIPALS AND AGENTS (1985) at 38-48).

61 See Mark A. Lemley, The Economics of Improvement in Intellectual Property, 75 TEX. L. REV. 989, 1050-51 (1997) (discussing difficulties in negotiating in connection with Arrow's information paradox); Robert Merges, Intellectual Property Rights and Bargaining Breakdown: The Case of Blocking Patents, 62 TENN. L. REV. 75, 81-82 (1994) (same). For more on the Arrow Information Paradox and the problem of public goods see infra Part II.C.4(a).

62 See, Press Release: The 2001 Sveriges Riksbank (Bank of Sweden) Prize in Economic Sciences in Memory of Alfred Nobel, available on line at http://www.nobel.se/economics/laureates/2001/press.html.

63 See, e.g., George Akerlof, The Market for Lemons: Quality Uncertainty and the Market Mechanism, 84 Q. J. ECON. 488 (1970) (elucidating the classic example of the adverse selection problem known as the "lemons problem").

64 See, e.g., A. Michael Spence, Job Market Signaling, 87 Q.J. ECON. 355 (1973) (showing how education can serve as a form of signaling for productivity in the job market).

65 See, e.g., Michael Rothschild \& Joseph Stiglitz, Equilibrium in Competitive Insurance Markets: An Essay on the Economics of Imperfect Information, 90 Q. J. ECON. 629 (1976) 
associated with transactions generally and so are also discussed more fully below in the section on transaction costs. ${ }^{66}$

The problem of appropriability is closely related to the problem of externalities because one way to view appropriability is as a form of positive eternality. As a result, appropriability is discussed more fully below in the section on externalities. ${ }^{67}$

The problem of information asymmetry also relates to the problems of hidden action and hidden information and the distinction between them, which arise whenever one is endeavoring to regulate the behaviors of another. As a result, these are discussed more fully below in the section on the theory of the principal/agent interaction and in the section on the theory of government. ${ }^{68}$

A central lesson to be taken from the NIE literature on information costs for purposes of this discussion is that IP rights can operate directly to mitigate some information problems - like the Arrow Information Paradox. ${ }^{69}$ Another lesson is that IP rights can operate indirectly to mitigate many of the other information problems. IP rights can achieve this effect through the transactions required to negotiate over an IP right to exclude better than the alternatives of government regulation through use of liability rules or direct government provision through subsidy.

\section{Behavioralism}

The term "behavioralism" refers to all of the ways in which human beings are not perfectly rational in decision making and instead are said to be only boundedly rational in that they suffer cognitive biases, framing effects, employ heuristics, etc. $^{70}$ While some scholars, such as Posner, have suggested that

(elucidating how an uninformed party can give informed parties incentives to reveal pertinent information about themselves, a method referred to as "screening").

66 For a discussion of transaction costs see infra Part II.B.2.

67 For a discussion of externalities see infra Part II.B.1.

68 For a discussion of agency costs see infra Part II.B.3. For a discussion of government see infra Part II.C.3.

69 See infra Part III (discussing IP theory).

70 For an excellent recent review of behavioralism literature see, e.g., Russell Korobkin, Bounded Rationality, Standard Form Contracts, and Unconscionability, 70 U. CHI. L. REV. 1203 (2003) (collecting sources). As noted by Troy Paredes, "Explaining and understanding these deviations from perfect rationality make up the core of [the field known as] behavioral law and economics." Troy A. Paredes, Blinded by the Light: Information Overload and Its Consequences for Securities Regulation, 81 WASH. U. L.Q. 417, 434-444 (2003) (collecting sources) (citing Behavioral Law \& ECONOMics (Cass R. Sustein ed., 2000); Christine Jolls et al., A Behavioral Approach to Law and Economics, 50 STAN. L. REV. 1471 (1995); Russell Korobkin, A MultiDisciplinary Approach to Legal Scholarship: Economics, Behavioral Economics, and Evolutional Psychology, 41 JuRIMETRICS J. 319 (2001); Korobkin \& Ulen, supra note 36; Jennifer Arlen, Comment: The Future of Behavioral Economic Analysis of Law, 51 VAND. L. REV. 1765 (1998)). 
decision-making under conditions of behavioralism can be thought of as same thing as perfectly rational decision making in a world of positive information costs, ${ }^{71}$ other scholars, such as Williamson, suggest behavioralism really refers to something more complex. ${ }^{72}$ As explained by Williamson, the problems of behavioralism include the problems of situations that simply are impossible to think through, ${ }^{73}$ the problems of misconception, like short-sightedness and incorrectly assessing probabilities, the problems of being rushed to make decisions, ${ }^{74}$ and the limitations of language. ${ }^{75}$ At bottom, according to Williamson, an especially productive way to conceptualize the problems of behavioralism is taught by Simon as the "idea of the mind as a scarce resource."76

Regardless of precise etiology, the problems of behavioralism have a number of manifestations. Decision-making processes reveal strategies that, using the terminology of Simon, seek to "satisfice" rather than "optimize;" or in the more modern parlance, employ "heuristics," as explored more recently in the work by Amos Tversky, Daniel Kahneman, and Paul Slovic, ${ }^{77}$ which formed part of the basis for which Kahneman shared the 2002 Nobel Prize in Economics. ${ }^{78}$ Other manifestations include risk and loss aversions, ${ }^{79}$ and various cognitive biases such as primacy and recency, ${ }^{80}$ framing, ${ }^{81}$ anchoring, ${ }^{82}$ and overoptimism,

Cf, Richard A. Posner, Rational Choice, Behavioral Economics, and the Law, 50 STAN. L. REV. 1551 (1998) (commenting on the behavioralism literature in general and in particular Jolls et al. supra); Becker supra note 38.

71 Posner, NIE Meets L\&E, supra note 32, at 80. This view of behavioralism is consistent with the types of information costs described earlier as the costs of obtaining and processing information. See supra notes 54-58, and accompanying text.

72 Williamson supra note 32, at 109-110.

73 Id. (citing Herbert Simon, Theories of Bounded Rationality, in DECISION AND OrganiZATION, 161 (C.B. McGuire \& R. Radner, eds., 1972)).

74 Id. (citing Oliver E. Williamson, Calculativeness, Trust, and Economic Organization, 36 J. LAW \& ECON. 453 (1993) (problems of being rushed to make decisions)).

75 Id. (citing Michael Polanyi, Personal KnOwledge: Towards a Post-Critical PhilOSOPHY (1962)).

76 Id. (citing Herbert Simon, Rationality as Process and Product of Thought, 68 AM. ECON. REV., 1, 12 (1978)).

77 Paredes supra note 70, at 435-36 (citing Herbert A. Simon, A Behavioral Model of Rational Choice, 69 Q.J. Econ. 99, 262-64 (1955); JUDGMENT UNDER UNCERTAINTY: HEURISTICS AND BiAses (Daniel Kahneman et al. eds., 1982); JOHN W. PAYNE ET AL., ThE AdAPTIVE Decision Maker 1-2 (1993); Herbert A. Simon, Models of Bounded Rationality: ECONOMIC ANALYSIS AND PUBlic POLICY (1982)).

78 See, Press Release: The Bank of Sweden Prize in Economic Sciences in Memory of Alfred Nobel 2002, available on line at http://www.nobel.se/economics/laureates/2002/press.html.

79 For the basic exploration of methods for measuring risk aversion see KENNETH J. ARROW AsPeCtS OF THE THEORY OF RISK-BEARING (1965); John W. Pratt, Risk Aversion in the Small and in the Large, 32 ECONOMETRICA, 122 (1964).

80 Jeffrey J. Rachlinski, The Uncertain Psychological Case for Paternalism, 97 Nw. U. L. REV. 1165, 1169-70 (2003) ("psychologists have found that when individuals are asked to 
overconfidence, and egocentricism. ${ }^{83}$ One central lesson on behavioralism from NIE is that because it impacts individuals regardless of whether they are in the private sector or the public sector, and whether they are acting as individuals or in groups, the mere identification of behavioralism as a problem does not alone indicate whether decision-making should be left to individuals or not.

A final dimension of the behavioralism problem that certainly strikes at the individual level but essentially is driven by interactions among individuals is the problem known as "groupthink." 84 There are several components to the groupthink problem. One involves the heuristic individuals use to avoid having to re-think problems that they think already have been thought through sufficiently by trusted others, thereby creating what Cass Sunstein describes as an "information cascade." 85 Presumably, the opposite effect is also seen, whereby the heurist is one of mistrust, not trust, and so the information content takes on the

memorize a long sequence of words, they are more likely to remember the first few words (the "primacy" effect) and the last few words (the "recency" effect) much better than the words in the middle of the list") (citing Eugene B. Zechmeister \& Stanley E. Nyberg, Human Memory: AN INTRODUCTION TO RESEARCH AND THEORY 60-71 (1982) (reviewing research on primacy and recency effects in memory)).

${ }_{81}$ For empirical evidence of framing effects see, e.g., Daniel Kahneman \& Amos Tversky, Choices, Values, and Frames, 39 AM. PsYCHOL. 341 (1983) (framing effects observed in decisions involving lotteries and other risky monetary payoffs); Amos Tversky \& Daniel Kahneman, The Framing Effect of Decisions and the Psychology of Choice, 211 SCIENCE 453 (1981) (same).

82 Rachlinski supra note 80 at 1171 ("When making numeric estimates, individuals will tend to rely heavily on reference points and then adjust from these reference points") (citing Tversky \& Kahneman supra note 81 1128-30 (explaining anchoring and the related process of adjustment)).

83 Rachlinski supra note 80 at 1172 (defining "overoptimism, which consists of overestimating one's capabilities; overconfidence, which consists of overestimating one's ability to predict outcomes; and egocentricism, which consists of overstating the role that one has played in events in which one has participated"). See also Paredes supra note 70, at 481 ("Some of the most well-known sources of these deviations from rationality include loss aversion, framing, the representativeness heuristic, the availability heuristic, overoptimism, and overconfidence.")

${ }^{84}$ See Troy A. Paredes, Too Much Pay, Too Much Deference: Is CEO Overconfidence the Product of Corporate Governance?, at 60, n. 227 (2004) (discussing groupthink in the context of corporate governance and as a contributing factor to CEO overconfidence) (working paper, copy on file with author) (citing IRVING L. JANIS, GROUPTHINK (2d ed. 1982) and Marleen O'Connor, The Enron Board: The Perils of Groupthink, 71 U. CIN. L. REV. 1233 (2003)).

${ }^{85}$ See id., at 12 (citing Timur Kuran \& Cass R. Sunstein, Availability Cascades and Risk Regulation, 51 STAN. L. REV. 683, 683-691, 720-23 (1999) (describing the problem as one of "informational cascades" through which a view cascades through a pool of individuals as each individual adopts the view of those believed to be better informed); CASS R. SUNSTEIN, Conformity and Dissent, U. ChicAgo LaW \& ECONOMics, Olin WORKIng PAPER No. 164 (available on-line at http://ssrn.com/abstract=314880)). 
opposite sign. ${ }^{86}$ Put differently, a related component, also explored by Sunstein, is that individuals may appear to change or even actually change their views and behaviors in response to perceived peer pressure. ${ }^{87}$ As Troy Paredes points out, going along may be a particularly attractive strategy, if little else. ${ }^{88}$ What is more, once group think has set in, there may be a lock-in effect, as pointed out by Arrow:

[Social and political] agreements are typically harder to change than individual decisions. When you have committed not only yourself but many others to an enterprise, the difficulty of changing becomes considerable... ${ }^{89}$

At bottom, groupthink can have important implications for the way norms operate, as discussed below. ${ }^{90}$

Finally, an additional component of the groupthink effect is tied to the phenomena of fashion. Sometimes a particular behavior, view, slogan, manner, or appearance is desired in its own right, as an affirmative expression of a discrete fashion preference - a fashion statement. ${ }^{91}$ And, as evidenced by the cyclical nature of changes over time in width of neck ties or length of skirts, fashion is fickle and so the fashion effect may be either to conform to the groupthink or to deviate from it. That is, an individual might either adopt or eschew groupthink as an affirmative fashion statement. Put differently, sometimes the culture is in fashion and sometimes the counter-culture is in fashion. Implications of fashion can be particularly important for the IP regime of trademark law, ${ }^{92}$ as well as for the way consumption patterns evolve in the entertainment industry. ${ }^{93}$

86 To be sure, this opposite component of the effect can be seen to be encompassed by the elucidation from Timur and Sunstien, but its express statement here is made simply to make its existence clear.

87 Kuran \& Sunstein, supra note 85 at 723-725.

88 See Paredes supra note 84, at 13.

89 Kenneth Arrow, The Limits OF Organization, (1974) at 128.

90 See infra Part II.C.1.

91 The desirability of a slogan as a fashion statement in and of itself is tied to a controversial issue in trademark law relating to marks that are desired in and of themselves, unconnected to a good or service. For more on this see infra Part IV.A.

92 See infra Part IV.A (discussing trademark law).

93 See infra Part IV.B (discussing role of norms in payment systems in the entertainment industry). 


\section{B. Problems at the Inter-Individual Level}

When individuals interact with each other, another set of problems explored by NIE become most evident. ${ }^{94}$ These include, inter alia, the problems of externalities, transaction costs, agency costs, and coordination. As with the problems on the individual level discussed above, these problems at the interindividual level also are common across all settings: public and private, and when individuals are both atomistic, such as strangers interacting across an open market, and within hierarchies, such as firms or governments. ${ }^{95}$

\section{Externalities}

The term "externality" generally is used to refer to some cost or benefit that is external to a given economic decision-making system in that it is not factored into the decisions made by that system. Some definitions in the literature seem to define the term in relation to individuals, in that an externality is seen as something external to the decision-making of an individual. ${ }^{96}$ Other definitions in the literature see the term as referring to something external to the decisionmaking process of the entire market. ${ }^{97}$ Both uses can be somewhat misleading, especially in law and policy discussions, because if the decision-making process is working perfectly, then nothing will be completely external to the individual or the market. ${ }^{98}$ This, of course, is one of the insights of the path-breaking work by Ronald Coase that contributed to his being awarded the Nobel Prize in economics in 1992, and that was labeled by Stigler as the "Coase theorem." 99

94 See supra note 33 (pointing out that the term "individual" is used here to refer to both a single person, and a group of people when acting as a group, such as a firm or government agency).

95 See supra note 34 (pointing out that these effects are present in diverse settings).

96 See, e.g., Hal R. VARian, Microeconomic AnAlysis, 423 (3 ${ }^{\text {rd }}$ ed. 1992) ("When the actions of one agent directly effect the environment of another agent, we say that there is an externality") (emphasis in original).

97 Robert S. PindycK \& DANiel L. Rubinfeld, Microeconomics, 297, 617 (1989) ("Such costs or benefits are called externalities because they are "external' to the market." "In this chapter we study externalities - the effects of production and consumption activities not directly reflected in the market") (emphasis in original).

98 Richard A. POSNER, ECONOMIC ANALYSis OF LAW, 71 (6 ${ }^{\text {th }}$ ed. 2003) ("Even if 'externality' is defined as external to the market process or decision rather than to the [individual], it is still a potentially misleading usage since if transaction costs are low the market may operate efficiently despite the apparent presence of externalities.")

99 See supra note 1 (discussing Nobel Prize to Coase). See also, RonAld CoAse, ThE FIRM, THE MARKET, AND THE LAW 157 (1988). ("I did not originate the phrase, the 'Coase Theorem,' nor its precise formulation, both of which we owe to Stigler.”); GEORGE J. STIGLER, The TheOry OF PRICE, 113 (3d ed. 1966) (coining the term “[t]he Coase theorem" writing that it 
But the real power of the Coase Theorem is not that the problem of externalities is illusory because decision-making in the real world is perfect. ${ }^{100}$ Real decision-making, like everything else in the real world, is not perfect. Instead, the Coase Theorem teaches that the problem of externalities is entirely reciprocal and that the tough questions facing any real decision-making process are essentially how to best determine what the "correct" decision is, and how best to implement it.

A brief review of the historical context of the Coase Theorem elucidates the point. In the early 1900's the economist Arthur Pigou wrote about factory chimney soot as a problem of externalities imposed on others in the environment around the factory and argued that the proper use of taxes or subsidies could be used by the government to encourage such individuals to properly account for the benefits and harms they project on those around them. ${ }^{101}$ According to Pigou, "resources devoted to the prevention of smoke from factory chimneys" provide an "uncompensated service," or what some would call a positive externality, while smoke "inflicts a heavy uncharged loss on the community," or provides what some would call a negative externality. ${ }^{102}$

Coase was responding to Pigou by showing that government taxes or subsidies were not needed to ensure the perfect amount of externalities because under appropriate conditions, such as zero transaction costs, etc., a well defined allocation of entitlements among those impacted - in the case of the soot, either a right to emit it or a right to be free from it - would ensure that they traded with each other to achieve the same perfect result sought by Pigou. ${ }^{103}$

Coase continued by pointing out that of course the world is not perfect and therefore not all potential exchanges will occur, due to the presence of transaction costs and other imperfections. ${ }^{104}$ As a result, he urged that there be consideration of overall net costs and benefits to the alternative initial allocations, including the costs of any subsequent transactions that might be needed, with an eye towards ensuring that that the entitlement to the resource be allocated in such a way that

"asserts that under perfect competition private and social costs will be equal" and citing Ronald Coase, The Problem of Social Cost, 3 J. L. \& ECON. 1 (1960)).

100 See generally COASE supra note 99, at 157-186 (1988) (responding to a number of common misperceptions regarding the Coase Theorem).

101 See generally, Arthur C. Pigou, The Economics of Welfare 166-68 (1920). See also, Arthur C. Pigou, WeAlth AND Welfare (1912).

102 PigOU, THE ECONOMICS OF WELFARE, supra note 101, at 160-61.

103 See Coase, The Problem of Social Cost, supra note 99, at 105-6.

104 Id. at 115 (and noting that because of transaction costs "the initial delimitation of legal rights does have an effect on the efficiency with which the economic system operates"). 
the resource itself would most likely end up at its highest and best use. ${ }^{105}$ The essential policy implication on this point is therefore to compare carefully real costs and benefits of available institutional arrangements - such as different entitlement allocations, enforcement rules, or taxes and subsidies. ${ }^{106}$

For example, Coase's work laid an important part of the foundation for the later work by Harold Demsetz on the emergence of property rights as a tool for internalizing positive externalities. ${ }^{107}$ Demsetz argued that property rights emerge when the benefits of internalization outweigh its costs - when the good of concentrating benefits and costs on owners so they deploy resources more efficiently outweighs the bad of the transaction costs associated with recognizing those rights. ${ }^{108}$ As Demsetz pointed out

Because of the lack of control over hunting by others, it is in no person's interest to invest in increasing or maintaining the stock of the game. Overly intensive hunting takes place. Thus a successful hunt is viewed as imposing external costs on subsequent hunters - costs that are not taken into account fully in the determination of the extent of hunting and of animal husbandry. ${ }^{109}$

The resulting private ownership of land will internalize many of the external costs associated with communal ownership, for now, an owner, by virtue of his power to exclude others, can generally count on realizing the rewards associated with husbanding the game and increasing fertility of his land. ${ }^{110}$

Put differently, with the lack of property rights, "the underuse of animal husbanding and land management resources (skills and labor) led to near

105 Id. at 132 (arguing that we should ask "whether the gain from preventing the harm is greater than the loss which would be suffered elsewhere as a result of stopping the action which produced the harm").

106 Terry L. Anderson, Donning Coase-Colored Glasses: A Property Rights View of Natural Resource Economics, Distinguished Fellow Address presented to Australian Agricultural and Resource Economics Society, 13 February 2004, at 8 (copy of manuscript on file with author) ("Following Coase's lead, we need to carefully examine the institutions"). As a qualitative example, consider that the costs of using a government tax or subsidy approach include public choice costs, and administration costs, while the costs of using an entitlement delimitation approach include transaction costs and enforcement costs.

107 See Harold Demsetz, Toward a Theory of Property Rights, 57 AM. ECON. REV. 347, 356 (1967) (explaining the emergence of property rights in land among Labradorian Indians as a response to over hunting: "an owner, by virtue of his power to exclude others, can generally count on realizing the rewards associated with husbanding the game and increasing fertility of his land"). For more on the emergence of property right see infra notes 173-178, and accompanying text.

$108 I d$. at 353 (noting that property rights did not emerge among those living on the southwest plains because the benefits would have been less since there were no animals of commercial importance comparable to the furry animals of the north whose pelts were tradable and because the costs would have been more since the animals that were there tended to wander more).

$109 \quad I d$. at 351.

$110 \quad I d$. at 356. 
exhaustion of animal resources (food and clothing) ... [while the presence of property rights] provided incentives for individuals to make more use of the one set of resources so as to not waste, and indeed to replenish, the other."111 Thus, one lesson on externalities is that the use of appropriate property rights can be an effective tool for avoiding what otherwise might be externality problems. Importantly, as discussed in more depth below, property rights can also do much more than internalize externalities. ${ }^{112}$

A second lesson on externalities is that the words "positive" and negative" are both reciprocal. ${ }^{113}$ That is, in the case of the negative externality of soot, for example, the factory's neighbor would see a potential interference with the right to use the air as a reservoir free from emissions while the factory side would see a potential interference with the right to use the air as a reservoir in which to place the emissions. In this sense, there is no such thing as "an externality," in the singular, because externalities only come in pairs. What this means for the externality analysis is that it must be studied from both angles, with the understanding that otherwise the attractiveness of different institutional responses may likely turn on the angle from which the problem is viewed.

A third lesson on externalities is that in the real world many externalities turn out to be irrelevant to efficient allocation of resources. ${ }^{114}$ For example, in the case of positive externalities, such as the pleasure a visually aesthetic garden brings to many of those passersby who happen to see it regardless of whether they contributed to its upkeep, the keeper of the garden has clearly managed to fund its creation and maintenance without reaping specific contributions from those passers by. ${ }^{115}$ Put differently, the positive externalities the passersby enjoy have

111 Kieff, Commercializing Inventions, supra note 8, at 718, n.95.

112 See infra Part II.C.4 (discussing property rights generally, including their role in facilitating coordination).

113 See Coase, The Problem of Social Cost, supra note 99, at 122 ("If we are to discuss the problem in terms of causation, both parties cause the damage."). See also, Anderson, Donning Coase-Colored Glasses, supra note 106, at 3 ("Coase emphasized that because one use precludes the other, the costs are reciprocal."); A.W. Brian Simpson, Coase v. Pigou Reexamined, 25 J. LEGAL STUD. 53, 60 (1996) (describing one of the core ideas presented by Coase to be that "the problem of social cost [or externalities] is, at least to an economist, a reciprocal problem.").

114 See, DAVID D. HADDOCK, IRRELEVANT INTERNALITIES, IRRELEVANT EXTERNALITIES, AND IRRELEVANT ANXIETIES, Northwestern University School of Law, Law \& Economics Research Paper Series Research Paper No. 03-16 (2003) (available on-line at http://papers.ssrn.com/abstract=437221) (providing examples and models and citing James $\mathrm{M}$. Buchanan, \& William Craig Stubblebine, Externality, 29 ECONOMICA 371 (1962).

115 For other examples of such irrelevant positive externalities see Bernstein \& Nadiri, Interindustry R\&D Spillovers, Rates of Return, and Production in High-Tech Industries, 78 AM. ECON. REV. 429 (1988) (finding that, in recent years, social rates of return significantly exceeded private rates of return in five high-tech industries). 
not prevented the good from being produced. ${ }^{116}$ To be sure, the possibility of capturing some benefit from these users of the garden may be a factor a garden planner might consider when making decisions about how to fund the garden creation and maintenance processes; but those gains would have to be weighed against the costs of such metering techniques. As a result, many such externalities are found in the real world effectively to be irrelevant to decisionmaking because a sufficiently small number of individuals having sufficiently great interest in the externalities are able to engage in sufficient private ordering for the appropriate amount of the desired activity to take place. ${ }^{117}$ Put simply, the point is that in many cases things that generate positive externalities would be made anyway, whether that positive externality is fully internalized to the producer or not.

\section{Transaction Costs}

Transaction costs are particularly important to the field of NIE because "transaction-costs economics is the original centerpiece of what Williamson ... called the New Institutional Economics."118 There has since been substantial empirical support for the validity of the transaction costs implications of NIE, as elucidated by Paul Joskow and others. ${ }^{119}$

The term "transaction cost" generally refers to all the costs associated with contracting among individuals, including the hassle those parties experience in finding and dealing with each other, the costs of lawyers and other professionals to arrange the deals, and the bargaining process itself. Transaction costs also can be thought of as including information costs. ${ }^{120}$ The term encompasses the costs

116 In economic terminology, these uses are said to be "inframarginal," as opposed to "marginal," Haddock, supra note 114, at 24 ("Transaction cost for collective goods-even those demonstrably enjoyed by millions - are chronically overestimated in policy discussions. Only one or a few strong demands often determine both actual and ideal provision, and even two million demands are irrelevant if inframarginal.").

117 Id., at 1-2 (citing Buchanan \& Stubblebine supra note 114).

118 FURUBOTN \& RICHTER, supra note 20, at 176 citing Williamson supra note 1, at 1.

119 See, e.g., Paul L. Joskow, Vertical Integration and Long-Term Contracts: The Case of Coal-Burning Electric Generating Plants, 1 J.L. Econ. \& ORG., 33 (1983); Paul L. Joskow, Asset Specificity and the Structure of Vertical Relationships: Empirical Evidence, 7 J.L. ECON. \& ORG., 95 (1988). See also Howard A. Shelanski and Peter G. Klein, Empirical Research in Transaction Cost Economics: A Review and Assessment, 11 J.L. ECON. \& ORG., 335 (1995) (survey of empirical evidence on transaction-costs economics assessing roughly 100 references on empirical research in transaction-cost economics published before 1993).

120 See, Armen A. Alchian, Information Costs, Pricing, and Resource Unemployment, 7 W. ECON. J. 109 (1969). See also, Stigler, supra note 55 (noting that acquiring and processing information about potential exchange opportunities are costly). 
of successful transactions - such as time and money - as well as the costs of failed transactions - such as lost opportunities.

Transaction costs became a focus of study in the NIE literature when they essentially were discovered by Coase in his path-breaking work on the theory of the firm, in which he pointed out that when making the decision about whether to make or buy it must be considered that moving activities into a firm can save on the transaction costs associated with conducting those activities in the open market. $^{121}$ As summarized by Coase in later work:

In order to carry out a market transaction it is necessary to discover who it is that one wishes to deal with, to inform people that one wishes to deal with and to what terms, to conduct negotiations leading up to a bargain, to draw up the contract, to undertake the inspection needed to make sure that the terms of the contract are being observed, and so on. ${ }^{122}$

Put differently, these can be viewed as a set of six types of transaction costs: search, inspection, contracting, execution, control, and enforcement. ${ }^{123}$ In addition, because each of these activities hinges on interactions among individuals, the term transaction costs is taken to encompass the problems on the individual level discussed earlier, including information costs and behavioralism. $^{124}$

The path-breaking work by Williamson adds to this set the transaction costs of asset specificity and opportunism, both of which become most relevant after individuals have begun to interact with each other. Williamson explains that asset specificity refers to the problem that arises when an asset cannot be redeployed from its present use to some alternative use without a decline in value. ${ }^{125}$ He defines ex post opportunism to be "[s]elf-interest seeking with guile, [including] calculated efforts to mislead, deceive, obfuscate, and otherwise confuse." 126

121 Ronald Coase, The Nature of the Firm, 4 ECONOMICA 386 (1937). For a review of modern transaction costs literature see Oliver E. Williamson, THE MECHANiSMS OF GOVERNANCE (1996).

122 Coase, The Problem of Social Cost, supra note 99, at 15.

123 FURUBOTN \& RichTER, supra note 20, at 291.

124 See supra Parts II.A.3-II.A.4.

125 Oliver E. Williamson, The Economic Institutions of CAPitalism, 52-56 (1985) (reviewing history of scholarship on asset specificity, collecting sources, and pointing out that "[a]t least four types of asset specificity are usually distinguished: site specificity, physical asset specificity, human asset specificity, and dedicated assets... [and that t] ime importance of asset specificity to transaction costs economics is difficult to exaggerate.").

126 Williamson, The Mechanisms of GovernANCE, supra note 121, at 378 . See also Williamson, The ECONOMiC Institutions of CAPITALiSM, supra note 125, at 47-52, 64-67 (exploring in detail various types of opportunism within the context transaction cost economics and collecting sources). 
Importantly, there is both a good and bad side to transaction costs. While on the bad side, they are costs, on the good side, they are the costs that are associated with the very specialization and division of labor that generally are thought to be good things. ${ }^{127}$ That is, the availability of transactions to obtain from others the goods and services beyond those an individual is most interested in or most adept at providing itself facilitates each individual's ability both to have and to hone those specialized skills and tastes, as well as to bear individualized distributions. The link between specialization and transactions allows even large numbers of individuals to achieve complex tasks by coordinating with each other directly or indirectly. ${ }^{128}$

In addition, given such individualism in the form of diverse skills and preferences, transactions, and their concomitant costs, have other important beneficial side effects that often are overlooked. First, transaction costs are associated with the privately beneficial exchanges among individuals that are essential for achieving private gains from trade. ${ }^{129}$ Second, transaction costs are associated with the publicly beneficial socialization that occurs as individuals come to interact with each other. ${ }^{130}$ The socialization effect occurs because for

127 John J. Wallis \& Douglass C. North, Measuring the Transaction Sector in the American Economy, 1870 -1970, in LONG-TERM FACTORS IN AMERICAN ECONOMIC GROWTH, 95 (Stanley L Engerman \& Robert E. Gallmann, eds.) (Studies in Income and Wealth, No. 51, 1986). The connection between division of labor and transaction costs, including the inevitable limit that transaction costs places on the extent of the division of labor, was articulated earlier by Adam Smith. See Harold Demsetz, The Cost of Transacting, 82 Q. J. ECON. 33, 35 (1968) (empirical evidence of transaction costs in the market of the New York Stock Exchange and quoting Adam Smith: "As it is the power of exchanging that gives occasion to the division of labor, so the extent of this division must always be limited by the extent of that power, or, in other words, by the extent of the market.").

128 For more on coordination see infra Part II.B.4.

129 See, Robert Ellickson, Order Without Law: How Neighbors Settle Disputes 184 (1991) (pointing out that societies tend to develop institutions - such as norms in the case he is studying - that "minimize the members' objective sum of (1) transaction costs and (2) deadweight losses arising from failures to exploit potential gains from trade."). See also, Coase The Problem of Social Cost, supra note 99, at 10. (noting that the principal condition that must be satisfied for individuals to maximize wealth by engaging in an exchange is that the transaction costs of the exchange must not exceed the gains from trade.); Terry L. Anderson \& Donald R. Leal, Free Market Environmentalism: Hindsight and Foresight, 8 CORNELL J.L. \& PUB. POL'Y 111113 (1998) ("[H]umans interact to capture potential gains from trade - the knowledge for this interaction is bounded by transaction costs. The gains from trade (a positive-sum game) result because people place different values on goods and services and because people have different abilities to produce those goods and services. Because of these differences, trade has the potential to make the parties exchanging goods and services - of lower value to each respectively - better off.")

130 See, e.g., Milton Friedman, Value Judgments in Economics, in THE ESSENCE OF FRIEDMAN 3, 3-8 (Kurt R. Leube, ed., 1987) (discussing the "role of the market as a device for the voluntary cooperation of many individuals in the establishing of common values" and concluding 
transactions to achieve gains from trade it must be the case that individuals having diverse resources and preferences learn enough about each other's resources and preferences to exploit them, and this process of learning about each others' values is part of socialization. Third, the bargaining process - for both consummated transactions and for failed ones - inherently elicits important information about not only the particular transaction being negotiated, including intensity of preferences and budget constraints, but also relative values compared to other available transactions. That is, transaction costs can mitigate information costs. Because these beneficial effects of transactions are often totally absent from discussions of the transactions that must occur around an IP right's right to exclude, an important lesson of NIE is that these effects must be considered when evaluating IP.

The net impact of those employed to facilitate transactions, such as lawyers and other professionals, is similarly ambiguous. Often they are portrayed as a large component of the negative side of transaction costs. ${ }^{131}$ Yet, because they help the transactions occur, ${ }^{132}$ they also can be seen as part of the positive side of transactions costs to the extent that the transactions themselves are a good thing.

Another important lesson of transaction costs economics is that, all-in, the likelihood and extent of the pernicious impact of many types of transaction costs

that "[i]n many ways, this is the basic role of the free market in both goods and ideas - to enable mankind to cooperate in this process of searching for and developing values.").

131 See, e.g., Ronald J. Gilson, Seeking Competitive Bids Versus Pure Passivity in Tender Offer Defense, 35 StAn. L. REV. 51, 62-63 (1982) ("Let me start with two important elements of transaction costs in the acquisition setting: information costs necessary to identify the opportunity; and mechanical costs - for example, lawyers', accountants', and investment bankers' fees necessary to effect the transaction and cope with regulatory or other barriers (including defensive tactics by the target).").

132 See, e.g., Troy A. Paredes, A Systems Approach to Corporate Governance Reform: Why Importing U.S. Corporate Law Isn't the Answer, 45 WM. \& MARY L. REV. 1055, 1110-12 (exploring Gilson's analytical framework of the lawyer as transaction cost engineer and citing Ronald J. Gilson, Value Creation by Business Lawyers: Legal Skills and Asset Pricing, 94 YALE L.J. 239, 255 (1984) (describing lawyers as "transaction cost engineers"); Bernard Black \& Reinier Kraakman, A Self-Enforcing Model of Corporate Law, 109 HARV. L. REV. 1911, 1923 (1996) (pointing out that in addition to lawyers "savvy investors and issuers" also help facilitate transactions); Curtis J. Milhaupt \& Mark D. West, The Dark Side of Private Ordering: An Institutional and Empirical Analysis of Organized Crime, 67 U. CHI. L. REV. 41, 58 (2000) (also using term "transaction cost engineers" for lawyers)). See also, Lisa Bernstein, The Silicon Valley Lawyer as Transaction Costs Engineer?, 74 OR. L. REV. 239, 241 (1995) (further exploring Gilson's analytical framework of the lawyer as transaction cost engineer and, in addition to Gilson, also citing Lawrence M. Friedman et al., Law, Lawyers, and Legal Practice in Silicon Valley: A Preliminary Report, 64 IND. L.J. 555, 562 (1989) ("[t]he Silicon Valley lawyer not only works with engineers, he thinks of himself as a kind of engineer -- a legal engineer ... his job is to solve problems, to take a principle, a task and engineer it legally")). 
is generally worse in what are known as thinner markets as compared with thicker markets, where thinner and thicker refer to the amount and diversity of resources and participants, including their diverse evaluative techniques and preferences. ${ }^{133}$ The intuition behind this lesson is essentially that thickness increases the chance some individual in the market will find it profitable to arbitrage what otherwise would be a gap in information flow by finding and acting on that information, to offer an attractive option for what otherwise might be a hold-up problem, etc.

To be sure, there is reason to think that some types of transaction costs may be worse in markets that are thicker, in at least some sense. For example, the behavioralism logic behind the problem of groupthink suggests that as the group gets bigger the problem gets worse. ${ }^{134}$ Of course, to the extent that thicker is taken to mean not only bigger but more diverse, then the problem of group think may also decrease with market thickness.

A somewhat related lesson of transaction costs economics is that, all-in, the likelihood and extent of the pernicious impact of most transaction costs is generally worse in political markets than in economic markets. ${ }^{135}$ As pointed out by North when contrasting the two:

economic markets throughout history, and in the present world, are frequently very imperfect, beset by high transaction costs, and defined by institutions that produce incentives to work against economic efficiency.

Political markets are far more prone to inefficiency. ${ }^{136}$

Although in part due to transaction costs, the many problems raised by political markets are explored in greater depth below in the discussion of public choice. ${ }^{137}$

\section{Agency Costs}

The term "agency cost" generally refers to all the costs associated with the inevitable divergences in the interests among two individuals in situations in

133 The so-called efficient market hypothesis (also known as "EMH") is based on the view that in a perfectly thick market, assets will be perfectly priced. The basic theoretical foundation for the EMH was laid by Paul Samuelson and Benoit Mandelbrot. See Paul A. Samuelson, Proof That Properly Anticipated Prices Fluctuate Randomly, 6 Indus. MgmT. Rev. 41, 48 (1965); Benoit Mandelbrot, Forecasts of Future Prices, Unbiased Markets, and Martingale Models, $39 \mathrm{~J}$. Bus. 242, 248 (1966). Empirical support was added by Eugene Fama. See Eugene Fama, Efficient Capital Markets: A Review of Theory and Empirical Work, 25 J. FIN. 383, 392 (1970).

134 For more on groupthink see supra note 84, and accompanying text.

135 For an in-depth treatment of the topic see Douglass C. North, A Transaction Cost Theory of Politics, 2 J. THEORETICAL POL. 355 (1991).

136 Douglass C. North, Institutions and Credible Commitment, 149 J. Institutional \& THEORETICAL ECON., 11, 18 (1993).

137 For more on the problems of government and public choice see infra Part II.C.3. 
which one individual (known as an agent) acts on behalf of the other (known as a principal). As summarized by Michael Jensen and William Meckling:

\begin{abstract}
The principal can limit divergences from his interest by establishing appropriate incentives for the agent and by incurring monitoring costs designed to limit the aberrant activities of the agent. In addition in some situations it will pay the agent to expend resources (bonding costs) to guarantee that he will not take certain actions which would hard the principal or insure that the principal will be compensated if he does take such actions .... In most agency relationships the principal and the agent will incur positive monitoring and bonding costs (nonpecuniary as well as pecuniary). And in all there will be some divergence between the agent's decisions and those decisions which would maximize the welfare of the principal. ${ }^{138}$
\end{abstract}

Thus, agency costs can be seen to include the costs of the agent's looting, shirking, other inadvertent deviations from instructions, and bonding, and the costs of the principal's unmet reasonable expectations, monitoring, and enforcing.

In part, agency costs can be seen as particularized versions of the many problems discussed earlier. For example, the divergence in interests between agent and principal implicate the problems of incentives - a core component of agency costs is triggered by the drive to get the agent's incentives aligned with those of the principal. ${ }^{139}$ Similarly, many of the information costs explored earlier, including moral hazard and adverse selection, have formed a big part of the agency costs literature. ${ }^{140}$ For example, as elucidated in the path breaking work by James Mirrlees, which formed part of the basis for which he shared the 1996 Nobel Prize in Economics, ${ }^{141}$ the moral hazard problem can be mitigated by a properly designed incentive scheme. ${ }^{142}$ And of course the interactions needed for an agency relationship are merely one category of the transactions explored in the earlier discussion of transaction costs. ${ }^{143}$

Two particular aspects of the agency problem have special prominence in IP. The first concerns hierarchy in general. The second concerns innovation in particular.

138 Michael C. Jensen and William H. Meckling, Theory of the Firm: Managerial Behavior, Agency Costs and Ownership Structure, 3 J. FIN. ECON., 305, 308 (1976) (emphasis in original).

139 See supra Part II.A.1(discussing incentives).

140 See supra Part II.A.3 (discussing agency costs). See also FURUBOTN \& RICHTER, supra note 20, at 186-232 (exploring models of moral hazard and adverse selection in the context of agency costs).

141 See, Press Release: The Sveriges Riksbank (Bank of Sweden) Prize in Economic Sciences in Memory of Alfred Nobel for 1996, available on line at http://www.nobel.se/economics/laureates/1996/press.html.

142 See, e.g., John A. Mirrlees, The Optimal Structure of Incentives and Authority within an Organization, 7 BELL J. ECON. 105 (1976).

143 See supra Part II.B.2 (discussing transaction costs). 
Hierarchy is itself one of the core areas of study within the field of NIE. More particularly, the contrast between interactions among individuals through a market on the one hand and interactions among individuals within a hierarchy such as a firm or government on the other hand lies at the core of the early NIE literature by Coase on the theory of the firm. ${ }^{144}$ On the one hand, moving interactions within a hierarchy can avoid or mitigate many of those transaction costs associated with exchanges in the context of an open market. ${ }^{145}$ On the other hand, integration within a hierarchy has limits because of the decreasing returns to management due to several factors, including agency costs, such as those involving the agency relationship between owners and managers and those involving the agency relationship between managers and labor. ${ }^{146}$

As demonstrated through models of both the private and academic sectors, agency problems can be particularly acute when the agent is tasked to innovate because the process of innovation is itself particularly fraught with uncertainty and because information about an innovator's efforts is likely to be especially asymmetrical as between a technologically trained innovator and a nontechnologically trained manager. ${ }^{147}$ To be sure, relational contracting like that among individuals within a hierarchy is just one typical form of incomplete contracting for which there are well studied strategies to mitigate agency costs. ${ }^{148}$ Yet, the general uncertainty of allocating credit for innovation within a hierarchy combined with the problem of potential expropriation by control groups of the

144 See generally, Coase, The Nature of the Firm, supra note 121 (elucidating tension in theory of the firm between transaction costs avoidance and decreasing returns to management). See also Ronald H. Coase, The New Institutional Economics, 88 AM. ECON. REV. 72 (1998)("It is commonly said, and it may be true, that the new institutional economics started with my article 'The Nature of the firm' (1937).").

145 See supra Part II.B.2 (discussing transaction costs).

146 See, generally, FURUBOTN \& RICHTER, supra note 20, at 336-342 (discussing the limits of integration elucidated by WiLliAMSON, THE ECONOMIC INSTITUTIONS OF CAPITALISM, supra note 125 , at 138-142).

147 See, Bengt Holmstrom, Agency Costs and Innovation, 12 J. ECON. BeHAV. \& ORG. 305 (1989) (modeling agency costs in innovation and identifying attributes that make it comparatively more difficult as a production activity in which to solve ordinary principal/agent problems compared to ordinary production processes because of greater ex ante uncertainty, and asymmetric information about the innovator's efforts). See also, Wallace Huffman \& Richard E. Just, Setting Incentives for Agricultural Research: Lessons from Principal-Agent Theory, 82 AM. J. AG. ECON. 828 (2000) (applying principal agent theory to model different funding approaches for basic scientific research in the field of agriculture).

148 Williamson notes the general importance of repeat play, reputation effects, and other private enforcement techniques he collectively calls "private ordering" as tools for mitigating problems such as agency costs and asset specificity. See, e.g., Williamson, ThE EcONOMIC INSTITUTIONS OF CAPITALISM, supra note 125, at 163-68). 
reward associated with innovation operate synergistically to particularly impair incentives for innovation within a hierarchy. ${ }^{149}$

\section{Coordination and Private Ordering}

Another implication of specialization and division of labor ${ }^{150}$ is that often many diverse actors must interact with each other for a particular activity to be achieved effectively. ${ }^{151}$ In the context of IP, for example, the process of bringing a new invention to market after that invention has been made - a process called commercialization - often requires the coordination of inventors, financiers, labor, management, advertisers, and marketers. ${ }^{152}$ For such coordination to take place, each of these individuals must both identify and interact with each other, at least indirectly. ${ }^{153}$

On the other side of the coin, the ability to achieve coordination among large numbers of individuals further supports the ability for each individual to have particular skills and tastes beyond what is achieved with the mere availability of pair-wise transactions. ${ }^{154}$ That is, without the ability to coordinate, in the case of an invention for example, the inventor hoping to achieve commercialization would need to simultaneously serve as financier, production labor, management, advertiser, and marketer. ${ }^{155}$

149 FuRUBOTN \& RiCHTER, supra note 20, at 336-37 (highlighting Williamson's discussion of the problems of "causal ambiguity" and "general office instruction" (expropriation) leading to impaired incentives to innovate and citing WILLIAMSON, THE ECONOMIC INSTITUTIONS OF CAPITALISM, supra note 125, at 141-42)).

150 See supra note 127 and accompanying text (discussing transaction cost implications of specialization and division of labor).

151 For more on the general link among specialization, division of labor, and coordination, see generally, Gary S. Becker \& Kevin M. Murphy, The Division of Labor, Coordination Costs, and Knowledge, in THE ESSENCE OF BECKER, supra note 38, at 609.

152 See generally, Kieff supra note 8 at 707-712 (discussing role of patents in commercialization of inventions).

153 Id. To be sure, the interactions may be transitive, in that each individual might not directly interact with each other in a pair-wise fashion, but each does interact on the same broadly defined endeavor. That is, assuming individuals $\mathrm{A}$ through $\mathrm{E}$ are needed for commercialization to take place, individual A may not directly interact with each of the other individuals B through E, and individual $\mathrm{B}$ may not directly interact with individuals $\mathrm{A}$ and $\mathrm{C}$ through $\mathrm{E}$, and so forth, but each of the individuals will be interacting with the same invention commercialization process and with a least a subset of the group comprising A through E, which means that in effect each individual is interacting with each other at least by transitivity.

154 See supra notes 127-128 and accompanying text (discussing role of transactions between individuals in supporting individualized skills and tastes).

155 The recognition of this problem was indeed one of the motivating factors behind the present U.S patent system, which focuses on the importance of coordination to achieve invention commercialization. See, Giles S. Rich, The Relation Between Patent Practices and the AntiMonopoly Laws, 24 J. PAT. OFF. SOC’Y 159, 177 (Mar., 1942) (discussing incentive aspects of 
For IP, coordination can be particularly important because the subject matter protected by IP ideally is not yet the subject of successful commercialization, or perhaps not even known yet. ${ }^{156}$ As Frank Knight recognized, such uncertain and risky endeavors have a particularly strong need for coordination:

When uncertainty is present and the task of deciding what to do and how to do it takes ascendancy over that of execution, the internal organization of the productive groups is no longer a matter of indifference or mechanical detail. Centralization of this deciding and controlling function is imperative. ${ }^{157}$

To be sure, this is not a call for the strong form of centralized control, such as government. After all, coordination, or "centralization" as Knight calls it, can occur through different institutional arrangements and the availability of each ultimately provides an important set of options for use in different cases. As Eirik Furubotn and Rudolf Richter note: "collective action, but not necessarily state action is needed." 158 Quoting Arrow, they continue:

$[\mathrm{M}]$ any other departures from the anonymous atomism of the price system are observed regularly. Indeed, firms of any complexity are illustrations of collective action, the internal allocation of their resources being directed by hierarchical controls. ${ }^{159}$

Coordination may occur among individuals who are linked to each other through some social group such as family, friendship, or ethnic or religious identity. While coordination among those within a social circle such as a family does have some advantages of mitigating information costs and transaction costs, it also has some disadvantages - what Stephen Haber calls the problems of "crony capitalism" " 60 - including asset specificity and the non-fungible nature of the attributes that underlie the social connection, such as familial relationship. ${ }^{161}$ As

patent system and noting that one of its most important components "applies to the inventor but not solely to him, unless he is his own capitalist"). See also infra Part IV.A (discussing the commercialization theory of the patent system).

156 For more on the positive law rules for obtaining IP rights see infra Part IV. The basic reason these rules must operate in this way is to protect the reasonable investment backed expectations of third parties. See Kieff, Registering Patents, supra note 8 (exploring normative case for positive law rules for validity).

157 FRANK KNIGHT, Risk, UNCERTAINTY, AND PROFIT, 268 (1965).

158 FURUBOTN \& RICHTER, supra note 20, at 64.

159 Id. (citing Arrow, The Organization of Economic Activity, supra note 60, at 62).

160 STEPHEN HABER, CRONY CAPITALISM AND ECONOMIC GROWTH IN LATIN AMERICA: THEORY AND EVIDENCE (2002) [hereinafter "HABER, CRONY CAPITALISM"].

161 For discussions of the information cost and transaction cost benefits see, e.g., Barak D. Richman, Community Enforcement of Informal Contracts: Jewish Diamond Merchants in New York, (John M. Olin Center for Law, Economics \& Business, Discussion Paper No. 384, 2002); 
Troy Paredes explains within the context of corporate and securities laws: "when laws are in place, parties can rely less on personal and family relationships when transacting, allowing them to engage in transactions with strangers."

The NIE literature also is replete with work exploring the tension between achieving coordination within a hierarchy such as a firm on the one hand or among individuals in an open market who only interact via private ordering on the other hand. ${ }^{163}$ As Williamson notes when describing what is referred to as the "marvel of the market," "[o]f special importance to Hayek was the proposition that the price system, as compared with central planning, is an extraordinarily efficient mechanism for communicating information and inducing change." ${ }^{164}$ But he also noted that this requires spontaneous cooperation and coordination, in contrast with the "kind of cooperation among men that is conscious, deliberate, purposeful," which is referred to as the "marvel of internal organization." 165 Put differently,

Markets are characterized by high-powered incentives, which help to keep bureaucratice costs in check and support strong autonomous adaptation. Hierarchy, by contrast, has much weaker incentives and greater bureaucratic

Lisa Bernstein, Private Commercial Law In The Cotton Industry: Creating Cooperation Through Rules, Norms, And Institutions, 99 Mich. L. REV. 1724 (2001). For discussion of the problems relating to fungibility and asset specificity see HABER, CRONY CAPITALISM, supra note 160.

162 Troy A. Paredes, A Systems Approach to Corporate Governance Reform: Why Importing U.S. Corporate Law Isn't the Answer, 45 WM. \& MARY L. REV. 1055, 1064 (2004) (also noting that "Strong legal protections for shareholders expand the available pool of capital for businesses and entrepreneurs and facilitate contracting by shoring up shareholder rights.").

163 The term "private ordering" is used more broadly in this paper than it is in some of the NIE literature. Williamson, for example, often uses the term "private ordering" to refer to the various informal mechanisms to privately enforce contractual relationships as compared with formal legal process. See, e.g., Williamson, THE ECONOMic Institutions of CAPITAlism, supra note 125, at 163-68. (suggesting that repeat play and reputation can serve as "private ordering" tools for enforcement). Here, the term is used to refer to all private interactions entered into voluntarily by individuals as compared to those coerced by a hierarch, such as cooperation directed by management among different divisions within a firm or tax transfers directed by law among members of a state. For uses of the term private ordering as it is used here see, e.g., Henry E. Smith, Exclusion and Property Rules in the Law of Nuisance, 90 VA. L. REv. 965, 983 (2004) (using the term "private ordering" to refer to private voluntary exchanges, not to private enforcement); Thomas W. Merrill \& Henry E. Smith, Optimal Standardization in the Law of Property: The Numerus Clausus Principle, 110 YALE L.J. 1, 8 (2000) (using the term "private ordering" in the context of individual choice and freedom of contract); Richard A. Epstein, All Quiet on the Eastern Front, 58 U. CHI. L. REv. 555, 569 (1991) ("Within the context of Eastern Europe, property and economic protections are critical to the ability to turn nations and economies around from central planning to private ordering").

164 Oliver E. Williamson, The Evolving Science of Organization, 149 J. InSTITUTIONAL \& TheORETiCAl ECON., 36, 47 (1993) (citing Friedrich A. von Hayek, The Use of Knowledge in Society, 35 AM. ECON. REV., 519, 524-27 (1945)).

165 Id. (citing ChESTER BARNARD, THE FunCtIONS OF THE EXECUTIVE, 4 (1938)). 
costs but has superior ability in cooperative adaptation respects. If different transactions have differing needs for autonomous and cooperative adaptations, which they do, then the cost effective response is to align markets and hierarchies in a discriminating way. ${ }^{166}$

As Coase elaborated, "[t]he main reason why it is profitable to establish a firm would seem to be that there is a cost of using the price mechanism." "167 But as Williamson points out, such transaction cost market failures are only failures to the extent "that they involve transaction costs that can be attenuated by substituting internal organization for market exchange." 168 Indeed, in recognition that not everything can be done as well inside a firm, Williamson asked: "Why can't a large firm do everything a collection of small firms can do, and more?"169 According to Williamson,

selective integration, whereby integration realizes adaptive gains but experiences no losses, is not feasible. Instead, the transfer of a transaction out of the market into the firm is regularly attended by an impairment of incentives, and this type of difficulty will tend to be particularly severe where innovations are important. ${ }^{170}$

At bottom, as elucidated earlier by Coase, the choice of whether to coordinate within a firm or among individuals in a market essentially involves a balance among the competitive benefits and transaction costs of the open market on the one hand against the transaction-cost-saving benefits and agency and management costs of hierarchy on the other hand. ${ }^{171}$

Finally, coordination can be facilitated through the use of focal points. As Randy Calvert has pointed out, "[r]ecognizing or creating focal points is one

166 Williamson, supra note at 164 , at 49.

167 Coase, supra note 121 , at 390.

168 Oliver E. Williamson, The Vertical Integration of Production: Market Failure Considerations, 61 AM. ECON. REV. 112, 114 (1971) (exploring relative advantages of "once and for all contract," series of short term contracts, and outright vertical integration, as alternative options for firms).

169 Williamson supra note 195 at 131 . This problem is sometimes cited as the "Williamson Puzzle." See Jean Tirole, The Theory of Industrial Organization (1988). The problem is also explored in Coase, supra note 121, at 394 ("Why is not all production carried on by one big firm?”) (citing Frank Knight, Risk, Uncertainty, and Profit, Preface to the Re-Issue, London School of Economics Series of Reprints, No. 16 (1933)).

170 Williamson supra note 195, at 161. (included in the problems he identifies is the decrease incentive to innovate because of sharing with other divisions within the new merged firm).

171 See supra notes 144-146 and accompanying text (exploring tradeoff between market and firm). 
important way in which the players can successfully coordinate." 172 This type of focal point coordination can be achieved using property rights. The classic work by Harold Demsetz on the emergence of the institution of property rights focuses on their role in internalizing benefits and costs. ${ }^{173}$ Yet, within the field of IP, earlier work by the present author has explored the role of property rights as focal points in facilitating coordination among complementary users of an asset. ${ }^{174}$ Later, Demsetz also highlighted this coordination function of property rights when discussing the increased specialization of labor that has occurred over time:

Difficulties in stipulating and enforcing agreements so as to encourage and facilitate productivity-increasing cooperation between different owners come into play here. ${ }^{175}$

The legal institutions that define private ownership and guide exchange arrangements must become operative if the complexity that is inherent in specialization is to be productive. ${ }^{176}$

Indeed, recent empirical work by Oren Bar-Gill and Gideon Parchomovsky confirms such a coordination effect for IP rights. ${ }^{177}$ Thus, the use of property in this coordination sense can be seen as navigating between the Coasian poles of open market on the one hand and internal to a firm on the other hand. ${ }^{178}$

At bottom, a central lesson from NIE here is that property rights in IP can provide an important option for facilitating coordination. In this sense, property rights are options to achieving such coordination within families, firms, and government. $^{179}$

\section{Problems at the Institutional Level}

Each of the problems explored above manifests itself in different ways depending on the particular set of institutional arrangements under which individuals are operating. The NIE literature has explored extensively several paradigmatic institutions including, inter alia, laws, norms, markets,

172 Randy Calvert, The Rational Choice Theory of Social Institutions: Cooperation, Coordination, and Communication, in MODERn POLITICAL ECONOMY: Old TOPICS, NeW Directions 216, 244 (J.S. Banks and E.A Hanushek eds., 1995).

173 See supra notes 107-111, and accompanying text (discussing work by Demsetz).

174 See Kieff, Registering Patents, supra note 8, at 67-68 (citing Demsetz, supra note 173).

175 Demsetz, Toward a Theory of Property Rights II, supra note 4, at S657.

176 Id. at S664-5.

177 See Bar-Gill \& Parchomovsky, supra note 2.

178 See supra notes 144-146, and 163-171, and accompanying text (exploring tradeoff between market and firm). For more on property rights see infra Part II.C.4.

179 See infra Part II.C.4 (discussing property rights generally). See also infra Part III (discussing property rights in IP). 
governments, and property rights. Each institutional arrangement has been shown to offer strengths and weaknesses, the major lessons of which are highlighted below.

\section{Laws, Norms, and Problems of Enforceability}

As mentioned at the outset of the article, the field of NIE views institutions to be "the humanly devised constraints that structure human interaction... [including] formal constraints (rules, laws, constitutions), informal constraints (norms of behavior, conventions, and self imposed codes of conduct), and their enforcement characteristics." ${ }^{180}$ As evident from the definition, an important characteristic of institutions is their ability actually to constrain behavior; and of course different institutions exert this effect differently.

Much of the work in NIE looks at different approaches to formal legal regimes and compares their overall impact with respect to the many problems explored in the discussions above. Some view this work as the component of NIE that includes the traditional law and economics literature, which some in the NIE literature call "legal studies." 181 Comparative institutional analyses of IP law regimes that take into account the problems explored thus far are presented in greater depth in Parts III-IV below. For purposes of the discussion here, it is sufficient to note that while the enforcement characteristics of law traditionally have been the focus of study, important recent work including that by Cass Sunstein has focused on the expressive function of law. ${ }^{182}$ Under this view, law matters not only because of its ability to shape behavior through coercion, but also through its ability to communicate in a way that ultimately shapes norms. ${ }^{183}$

This leads to another central component of NIE, which looks at the different approaches to informal rules, often called norms, and compares their overall impact with respect to the many problems explored in the discussions

180 North, supra note 19.

181 See, Eirik G. Furubotn \& Rudolf Richter, Editorial Preface to Symposium Edition: The New Institutional Economics, Recent Progress; Expanding Frontiers, 149 J. InSTITUTIONAL \& THEORETICAL ECON., 1, 2-4 (1993) (reviewing "legal studies" as literature within the field of NIE and citing early major works such as RICHARD A. POSNER, ECONOMIC ANALYSIS OF LAW (1972) and Guido CAlabresi, The Costs of Accidents: A Legal AND ECONOMIC ANAlysis (1971)). An important recent component of this literature directed to the field of IP itself, but offering a different perspective than the present piece in that it does not directly most of the major lines of thought in NIE that are outside of the domain of classical law and economics, includes WILLIAM M. Landes \& Richard A. Posner, The Economic Structure of Intellectual Property LAW (2003).

182 See, e.g., Cass R. Sunstein, On the Expressive Function of Law, 144 U. Pa. L. Rev. 2021, 2035 (1996).

183 Id. at 2051-52 (concluding that law has an expressive function which operates through norms). 
above. Indeed, Williamson argues that the focus on positive law regimes reflects a type of "legal centrism" that fails to account adequately for dispute resolution and enforcement activities that occur without the formal legal system, what he terms "private ordering." 184 Norms can be thought of in at least two ways: as "prescriptive norms," also called "normative norms," which refer to beliefs about what people should do, and as "descriptive norms," or "regularities," which refer to how people tend to behave. ${ }^{185}$ Indeed, thus far the only significant connection between the literatures of IP and NIE has centered on the role of norms. ${ }^{186}$

Much of the NIE literature on informal, or non-legal ordering has focused on enforcement and dispute resolution. One example is the important work by Lisa Bernstein on relational contracting within homogeneous communities, which has focused on what it calls "private ordering" as a mechanism by which individuals in the market can interact with lower administrative costs than with formal legal institutions through the use of more informal institutions for enforcement and dispute resolution such as norms, reputation, etc. ${ }^{187}$ Similarly,

184 See, Williamson, The ECONOMic InSTITUTIONS OF CAPITALiSM, supra note 125, at 2021 (discussing "legal centrism"); See also supra note 163 (explaining Williamson's use of the term "private ordering" is more narrow than the use in this paper).

185 For a recent discussion of these two types of norms within the context of IP see, e.g. F. Scott Kieff, Facilitating Scientific Research: Intellectual Property Rights and the Norms of Science - A Response to Rai \& Eisenberg, 95 NW. U. L. REV. 691, 693, 696 (2001). To be sure, norms of each type may influence the other. What is more, when it comes to prescriptive norms about how individuals should behave, they may be driven by either external, or internal pressures. See, e.g., Paredes, supra note 162, at 1087-88 ("By 'norms' I do not mean those steps that managers take to please the market or to avoid shame or a lawsuit, although sometimes 'norms' is used broadly this way. Rather, I am referring to a sense of right and wrong - a sense of duty and responsibility - that directors and officers internalize and enforce on themselves simply because it is the right thing to do") (citing, inter alia, Lynn A. Stout, On the Export of U.S.-Style Corporate Fiduciary Duties to Other Cultures: Can a Transplant Take? 10 (UCLA School of Law, Working Paper No. 02-11, 2002), available at http://ssrn.com/abstract=313679 ("In lay terms, corporate insiders act like fiduciaries not only because they fear external sanctions, but also because they have internalized a sense of obligation or responsibility toward others ...'); Edward B. Rock, Saints and Sinners: How Does Delaware Corporate Law Work?, 44 UCLA L. REv. 1009, 1104, 1013 (1997) ("All of us internalize rules and standards of conduct with which we generally try to comply. We do this not only because we may fear some sanction, formal or informal, but also because doing so is important to our sense of self-worth, because we believe that doing a good job is the right thing to do.")).

186 See, e.g., Robert Merges, Contracting into Liability Rules: Intellectual Property Rights and Collective Rights Organizations, 84 CAL. L. REV. 1293 (1996) (exploring the role of norms in establishing private institutions to coordinate IP transactions); Arti Kaur Rai, Regulating Scientific Research: Intellectual Property Rights and the Norms of Science, 94 Nw. U. L. Rev. 77 (1999); Kieff, supra note 185.

187 See, e.g., Lisa Bernstein, Opting out of the Legal System: Extralegal Contractual Relations in the Diamond Industry, 21 J. LEGAL STUD. 115 (1992) (showing how some communities opt for informal private enforcement mechanisms for contractual relationships 
important recent work by Barak Richman comes closer to the theory of the firm literature and focuses on the importance of the private enforcement and dispute resolution techniques as means for ensuring not just lower administrative costs, but also better contractual enforcement, and enhanced transaction certainty. ${ }^{188}$

The view of property rights offered in this paper differs from both of these perspectives by seeing private ordering in the more general sense than simply private enforcement. ${ }^{189}$ Instead, private ordering is seen as the set of interactions among individuals that are more reliable because they are enforced in some way, whether by private informal institutions, such as norms, or by formal legal institutions, such as the coercive power of the state.

This view is consistent with traditional liberal views of the rule of law and role of government as the monopoly over the coercive powers - such as force - to back property rights and contractual arrangements because such backing enhances the overall market economy by enhancing individual liberty to elect to deploy one's resources in whatever way best suits that individual. ${ }^{190}$ While important recent work by Richman has shown that private enforcement mechanisms may, under appropriate conditions such as small and homogenous communities, provide even more transactional security at a lower administrative cost than public enforcement, ${ }^{191}$ the point here is that having the option of public

instead of formal legal approaches because the administrative costs can be lower). Bernstein's use of the term "private ordering" to refer to private enforcement is consistent with the use by Williamson, which is narrower than the use in this paper, which encompasses all private interactions voluntarily entered. See supra note 163 (contrasting Williamson's use of the term "private ordering"). See also Steven L. Schwarcz, Private Ordering, 97 Nw. U. L. REV. 319 (2002) (similar use of the term "private ordering" to refer to private enforcement or regulation).

188 Barak D. Richman, Firms, Courts, and Reputation Mechanisms: Towards a Positive Theory of Private Ordering, at 4 (working paper, forthcoming as 104 COLUM. L. REV. _ (2004) (available on-line at http://ssrn.com/abstract=565464) ("This paper argues that concerns over transactional assurance and contractual enforcement, not administrative costs, drive merchant communities to private ordering (and to vertical integration as well).")

189 See supra note 163 (discussing this more general use of the term "private ordering").

190 See, e.g., Douglass North, Institutions, Institutional CHANGE, AND Economic PERFORMANCE (1990) (elucidating the importance to economic growth of the reliable enforcement of property rights and contracts by formal public legal institutions); DougLASS C. NORTH \& ROBERT P. THOMAS, THE RISE OF THE WESTERN WORLD (1973) (putting property rights at the center of the explanation of economic performance); Avner Greif \& Eugene Kandel, Contract Enforcement Institutions: Historical Perspective and Current Status in Russia, in ECONOMIC TRANSITION IN EASTERN EUROPE AND RUSSIA: REALITIES OF REFORM (Edward P. Lazear, ed., 1995) (same). See also, Friedrich A. von Hayek, The Principles of a Liberal Social Order, in THE ESSENCE OF HAYEK, (Chiaki Nishiyama \& Kurt R. Leube, eds., 1984) (providing general discussion of the theory of liberal government including its use of coercive powers to enforce law).

191 Compare, Richman, supra note 188, at 24 (contrasting benefits and costs of, inter alia, private and public enforcement mechanisms under different conditions). 
enforcement is a benefit to those under other more generalized or diverse conditions. What is more, the option of public enforcement also helps allow such arrangements to be struck reliably without creating as much risk of asset specificity and opportunism that are associated with bringing such transactions entirely within a firm. ${ }^{192}$

\section{Markets and Market Failures}

One consensus lesson of economics, NIE and otherwise, is that markets are not perfect and they do fail. Indeed, each of the problems explored in the sections above and below can be, and often is, viewed as a type of "market failure." 193 Nevertheless, as suggested in the introductory discussion of a theory of second-best, the mere identification of market failure does not in and of itself justify a call for resolution because it is the all-in comparative analysis among truly available options that should drive policy. ${ }^{194}$ Put differently:

Traditional economics ascribes departures of actual market organizations from the idea type of perfect markets to monopolistic practices. The approach of [NIE], on the other hand, holds that because of transaction costs, and thus informational problems, such departures may serve economizing purposes. ${ }^{195}$

For example, rules limiting competition, such as those limiting access to the stock exchange can have many positive, or efficiency-promoting, effects: "The exchange organizes not only the conclusion of contracts but also all associated transaction activities (from search to enforcement)...."196 To be sure, this does

192 See supra notes 125-126, and accompany text (discussing asset specificity and opportunism).

193 See, e.g., Stephen Breyer, Analyzing Regulatory Failure: Mismatches, Less Restrictive Alternatives, and Reform, 92 HARV. L. REV. 549, 553-58 (1979) (exploring various market failures including externalities, monopoly, and information costs); Ian Ayres \& Eric Talley, Solomnic Bargaining: Dividing a Legal Entitlement to Facilitate Coasean Trade, 104 YALE L.J. 1027, 1029 (1995) (listing information costs, transaction costs, and externalities - what they refer to as "free riding" - as examples of market failure).

194 See supra notes 20-31, and accompanying text.

195 FuruBOtN \& Richter, supra note 20, at 291 (citing Williamson, The ECONOMIC Institutions of CAPITAlism, supra note 125) and citing Coase, Industrial Organization: $A$ Proposal for Research," VICTOR R. FUCHS, POLICY ISSUES AND RESEARCH OPPORTUNITIES IN INDUSTRIAL ORGANIZATION 59 (NBER, 1972) (“One important result of this preoccupation with monopoly is that if an economist finds something - a business practice of one sort or other - that he does not understand, he looks for a monopoly explanation.").

196 FURUBOTN \& RICHTER, supra note 20, at 302 (citing other examples such as "the evolution of 'privately ordered' medieval trade organizations as explored in [the following works:]" Avner Grief, Reputation and Coalitions on Medieval Trade: Evidence on the Maghribi Traders, 49 J. ECON. HIST., 857 (1989) (among long-distance Jewish traders in the Mediterranean during $11^{\text {th }}$ century called the Maghribi); Roger Milgrom, et al., The Role of Institutions in the 
not mean that all market failures should be embraced. Rather, the general point is that when thinking about market failures it is essential to keep track of the real costs and benefits of all available options. In addition, there are two more specific points that need to be kept in mind when thinking about the ways markets work or don't work within the context of IP, as discussed more fully below.

\section{(a) Ex Ante vs. Ex Post and Dynamic vs. Static Efficiency}

While there is debate about exactly how rational or irrational individuals are when they make decisions about whether and how to act there is consensus that individuals do make such decisions and do plan. ${ }^{197}$ The term "ex ante" refers to the time period before a decision is made about a given action. The term "ex post" refers to any of the times afterwards. That is, the information and other resources an individual has ex ante will impact the decision-making process.

This includes not only what is known, but what is expected. As a result, there can be feedback between the ex ante and ex post worlds because individuals interpret events in the world around them as having some predictive value for the way events in the future will unfold. As elucidated by the path breaking work on rational expectations by Robert Lucas, which formed part of the basis for which he was awarded the 1995 Nobel Prize in Economics, ${ }^{198}$ individuals constantly update and reinterpret information presently available to make best estimates about the future. ${ }^{199}$ In game theory terminology, the point is that life is a multicycle game, not a single-cycle game, and individuals may use information from past cycles of the game when making decisions about how to play future cycles. $^{200}$ Individuals may change their expectations about what may happen to a

Revival of Trade: The Law Merchant, Private Judges, and the Campagne Fairs, 2 ECON. \& POL. 1 (1990) (law merchant system of the Champaign Fairs of the twelfth and thirteenth centuries)). See also, Jonathan H. Adler, Conservation through Collusion: Antitrust as an Obstacle to Marine Resource Conservation, 61 WASH. \& LEE L. REV. 3 (2004) (elucidating how antitrust enforcement may interfere with environmental conservation and other goals).

197 See supra Part II.A.1 (discussing incentives and their relationship to decisions).

198 See, Press Release: The Sveriges Riksbank (Bank of Sweden) Prize in Economic Sciences in Memory of Alfred Nobel for 1995, available on line at http://www.nobel.se/economics/laureates/1995/press.html.

199 See, e.g., Robert E. Lucas, Expectations and the Neutrality of Money, 4 J. ECON. THEORY 103 (1972). See also, Sanford J. Grossman, An Introduction to the Theory of Rational Expectations Under Asymmetric Information, 48 REV. ECON. STUD. 541, 543 (1981) (describing rational expectations equilibrium).

200 Games that are not static are sometimes said to have multiple cycles, rounds, or iterations, or are said to repeat. For their pioneering work on game theory, John C. Harsanyi, John F. Nash, and Reinhard Selten were jointly awarded the Nobel Prize in economics in 1994. See Press Release: The Sveriges Riksbank (Bank of Sweden) Prize in Economic Sciences in Memory of Alfred Nobel for 1994 (available on-line at http://www.nobel.se/economics/laureates/1994/press.html). For a general overview of game 
given state of affairs in the future based on what they perceive happening to similar states of affairs in the present and past. If individuals perceive that property rights and contracts are not being enforced, they may have less faith in property rights and contracts being enforced in the future, all other things being equal. As investment in such property rights and contracts becomes less attractive, ordinary incentive analysis suggests that individuals will shift investments towards other activities. Indeed, the literature on private ordering places great emphasis on the role of ex ante predictability and certainty in property and contract enforcement for facilitating efficient investment and other decision-making over time, or in the dynamic sense. ${ }^{201}$

A problem with this dynamic approach is that can be in tension with other more static approaches to efficiency, which may see resource distributions at any point in time as sub-optimal. For example, a promise to make my car available to you at a particular time if you elect to use it then may put me in a position when that time arrives in which the car is not in use by anyone. ${ }^{202}$ In the static sense, at that moment in time, it may indeed look as though the car is being allowed to go to waste, which would be inefficient. Yet, if I am allowed to deploy the car to other uses out of fear for the risk that it might go unused then your expectation that it will be available for your use if you so chose will be dashed. What is more, if you know this ex ante, then you may not even be willing to enter into the contract to reserve the car in exchange for some other compensation, such as money, or you will be willing to pay only a lesser amount. Thus, in the dynamic sense, the future abrogation of the contract to provide the car, which presumably would make both you and me better off, which is why we would elect to enter into it in the first instance, is not a contract that we can consummate ex ante. As a result, over time we cannot engage in as many productive exchanges as otherwise. Put differently, there would be dynamic inefficiency. ${ }^{203}$

To be sure, it is recognized that recent important work by Ian Ayers and Eric Talley, and by Jason Scott Johnston elucidates how, due in large part to many

theory see, e.g., JOHN VON Neumann \& OSKar MORgEnstern, TheOry OF GAMES AND ECONOMIC BEHAVIOR (1944) (first formal treatment of game theory as a part of economics); Douglas G. BAIRD, ET AL., GAME THEORY AND THE LAW (1994) (more modern treatment of game theory with focus on legal implications).

201 See generally, Paredes, supra note 132, at 1133-34 ("Legal certainty, which is part and parcel of well-defined property rights, is a valuable asset that facilitates business and investing, aside from how the law actually allocates rights and responsibilities")

202 To be sure, this is a highly stylized example and in the real world every contract can have detailed insurance, futures, and options components. Indeed, the availability of these provisions provides justification for treating contracts among sophisticated parties as though they do indeed speak to these issues, even when silent on their face.

203 See generally, David D. Haddock et al., An Ordinary Economic Rationale for Extraordinary Legal Sanctions, 78 CAL. L. REV. 1, 16-17 (1990) (showing how uncertainty in enforcement discourages investment ex ante). 
of the behavioralism problems explored earlier, ${ }^{204}$ uncertainty in enforcement may in some cases improve the ability to negotiate over property rights and contracts by decreasing hold-out problems through a feed-back mechanism in which uncertainty makes more credible the threat of infringement or breach ex post, which may cycle back to decrease incentive ex ante for the rights-holder to hold out in the first instance. ${ }^{205}$ Nevertheless, other recent empirical work by Rachel Croson and Johnston shows that in other cases uncertainty degrades the ability to reach dynamic efficiency. ${ }^{206}$ Indeed, other work by Ayres and Robert Gertner elucidates the importance of at least some certainty - in that case what they term "penalty default rules - because it will have the impact of bringing to light information about potential negotiations and help avoid opportunism by one party attempting "to get a larger piece of the smaller contractual pie.".207 At bottom, at least in many cases private bargaining over property rights can be more efficient if the right is clearly defined ex ante according to a predictable rule, rather than made ex post by a judge applying a standard. ${ }^{208}$

The difference between ex ante and ex post, or dynamic and static efficiency, also matters beyond the narrow setting of individual transactions discussed above - although that is not irrelevant - because in many ways change is desirable in and of itself. For example, as resources such as fossil fuels become depleted, we must change to make use of alternative energy sources. Put simply, innovation that occurs over time can improve the size of the pie for everyone by making available more options. Thus, as Einer Elhauge has cautioned with respect to certain forms of antitrust enforcement motivated by concerns for static efficiency but that may negatively impact innovation:

204 See supra Part II.A.4 (exploring behavioralism problems).

205 Ian Ayres \& Eric Talley, Solomonic Bargaining: Dividing a Legal Entitlement to Facilitate Coasean Trade, 104 YALE L.J. $1027-1118$ (1995); Jason Scott Johnston, Bargaining under Rules versus Standards, 11 J.L. ECON. \& ORG. 256-281 (1995).

206 Rachel Croson \& Jason Scott Johnston, Experimental Results on Bargaining under Alternative Property Rights Regimes, 16 J.L. EcON. \& ORG. 50, 67-70 (2000).

207 Ian Ayres \& Robert Gertner, Filling Gaps in Incomplete Contracts: An Economic Theory of Default Rules, 99 YALE L.J. 87, 127 (1989).

208 ROBERT COOTER \& THOMAs UlEN, LAW AND ECONOMICs 100 (1988). For a discussion of the broader debate between legal systems based on rules and those based on standards, see generally MARK Kelman, A GUIDE TO CRITICAL LegAl StUdies 15-63 (1987) (describing basic framework of the debate and collecting sources); Louis Kaplow, Rules Versus Standards: An Economic Analysis, 42 DUKE L.J. 557 (1992) (exploring the costs implicated by the choice between rules and standards and showing: rules typically are more costly than standards to create; standards typically are more costly for individuals to interpret, both by individuals deciding how to act under them and by government decisionmakers deciding how to apply them; and individuals are more likely to act in accordance with the goals of rules as long as the individuals can determine how they will be applied); Russell B. Korobkin, Behavioral Analysis and Legal Form: Rules vs. Standards Revisited, 79 OR. L. REV. 23 (2000) (reviewing more recent literature and collecting sources). 
Such innovations make consumers and society better off by giving them new market options that are better (because they are cheaper or of higher quality) than the market options they would have had without the innovation. This is the most desirable form of market activity we can have. To condemn it is to fetishize the ex post avoidance of static allocative inefficiency under given cost and demand curves, and ignore the disastrous ex ante effects such a standard would have on dynamic productive efficiency that either raises demand curves by making the product more desirable or lowers cost curves by making the product cheaper to make. Repeated economic studies indicate the latter is far more valuable. ${ }^{209}$

Thus, the distinction between dynamic and static efficiency is particularly important for IP because it is focused on innovation.

\section{(b) Monopoly Effects}

The problem of monopolies is another specific point that must be kept in mind when thinking about the ways markets work or don't work within the context of IP. Because monopolies can create important inefficiencies, they have been the subject of substantial attention by both lawyers and economists. Indeed, the core purpose of antitrust law is "to root out unreasonable restraints of trade and transactions that substantially lessen competition or tend to create monopoly." 210 The central inefficiency associated with monopolies is the creation of dead weight loss by the monopoly's ability to set price above marginal cost, or to have power over price. ${ }^{211}$ But, there are several reasons why the extent of this inefficiency may not be the same in practice as it is in theory.

209 Einer Elhauge, Defining Better Monopolization Standards, 56 STAN. L. REV. 253, 275 (2003) (collecting sources). See also Christopher S. Yoo, Rethinking the Commitment to Free, Local Television, 52 EMORY L.J. 1579 (2003) (reviewing tension between static and dynamic efficiency within the context of public goods and monopolistic competition).

210 F. Scott Kieff \& Troy A. Paredes, The Basics Matter: At the Periphery of Intellectual Property, Stanford Law School John M. Olin Program in Law and Economics Working Paper No. 275, at 7, forthcoming _ G.W. LAW REV. _ (2004) (generally exploring the interfaces IP law shares with other regimes such as antitrust, and collecting sources including PHILLIP AREEDA \& Louis Kaplow, Antitrust Analysis: Problems, TeXts, Cases 174-250, 447-77, 785-806 (1997)). For a different take on the interface between IP and antirust see HERBERT HOVENKAMP, ET AL., IP AND ANTITRUST (2003).

211 This dead weight loss represents a collective loss of societal wealth, in that it is not merely wealth that has been shifted from consumers to producers but rather wealth that is altogether lost from producers and consumers collectively. The dead weight loss inefficiency associated with power over price is depicted graphically, and its etiology is explained in a manner targeted for a lay audience, in CHISUM, ET AL. supra note 5, at 60-66. To be sure, there are other inefficiencies associated with monopolies, including, for example, the rent dissipating effects that competition for monopoly profits may generate. See generally, Gordon Tullock, The Welfare Costs of Tariffs, Monopolies, and Theft, 5 W. ECON. J. 224 (1967) (seminal work on rent-seeking 
First, monopoly is a term that relates to a market, not to any particular good or service sold in that market. As Kenneth Dam has pointed out within the context of IP, for example:

\begin{abstract}
Indeed, it had become conventional to say that a patent is a monopoly. Nonetheless, it is readily apparent that the right to exclude another from "manufacture use and sale" may give no significant market power, even when the patent covers a product that is sold in the market. Indeed, without the benefit of empirical research, it is entirely plausible to conclude that in the great bulk of instances no significant market power is granted. We must bear in mind that leading companies may obtain 1,000 or more patents in a single year, and yet many such firms are unlikely ever to obtain even a single monopoly in any market. $^{212}$
\end{abstract}

There often is a difference between a product or service market and an IP asset. Consumers often buy computers that essentially involve the licensing of hundreds of licensed IP rights - for hard drive, processors, DRAM, other chips, etc without acting as direct customers of any of the IP owners.

Put differently, while in a certain sense every property right can be thought of as a monopoly, only those that convey effective control over an entire market can have the troubling economic inefficiencies associated with monopolies. For example, the owner of a hypothetical piece of real estate Blackacre can exclude use of that particular parcel, but must compete with other parcels of land in the market for land generally. Indeed, while the amount of real estate in the world actually is limited by the surface area of the planet, unless it turns out that the scope of human intellectual content is presently so close to the limit of its full potential there is no reason to think that for IP the long run monopoly impact of a given property right is likely to be any worse than for real property; and instead it is likely to be much less.

Second, the economic inefficiency that is associated with a monopolist's power over price is not inevitable. More specifically, the inefficiency is tied to the potential for a decrease in quantity (not an increase in price) as compared with the perfectly competitive model. If the monopolist is able to engage in perfect price discrimination, then the quantity produced will be the same as if there were competition and while the price charged at least some consumers will be higher, there will be no dead weight loss inefficiency. ${ }^{213}$ While perfect price

costs of monopoly). Yet, the rent dissipating effects of monopolies, like other rent dissipation, depends on several factors. For more on rent dissipation generally, see supra Part II.A.2.

212 Kenneth W. Dam, The Economic Underpinnings of Patent Law, 23 J.L. STUD. 247, 249250 (1994).

213 For those who are familiar with the graphical representation of the monopolist's dead weight loss triangle, an example of which is depicted in CHISUM, ET AL. supra note 5, at 65, price 
discrimination, like perfect anything, is not possible in the real world, the extent to which the monopolist can engage in price discrimination may mitigate the practical extent of the theoretical static inefficiency associated with monopoly dead weight loss. ${ }^{214}$

\section{Government, Government Failures, and Public Choice}

Like markets, government institutions have many strengths and weaknesses. One core role of government is to step in to provide services the market would fail to provide efficiently because of economies of scale or scope, or because of collective action problems, or positive externalities, with the paradigmatic example of a service that meets each criteria being national defense. ${ }^{215}$ Government also has the benefits of hierarchy explored earlier in the

discrimination allows the monopolist to convert what otherwise would be that dead weight loss triangle into being producer surplus instead.

214 For a basic overview of the economics of price discrimination, see JEAN TIROLE, THE THEORY OF INDUSTRIAL ORGANIZATION 133-68 (1997). It is also recognized that in certain cases efforts to engage in price discrimination may lead to decrease in efficiency. For example, recent work by Wendy Gordon, Glynn Lunney, and Michael Meurer has shown that while price discrimination by IP owners might lead in theory to more use in certain instances, in practice some price discrimination strategies can result in less output than if such price discrimination were prohibited, depending, in part, on the licensing arrangements employed to discriminate among users). Wendy J. Gordon, Intellectual Property as Price Discrimination: Implications for Contract, 73 CHI.-Kent L. Rev. 1367 (1998); Glynn S. Lunney, Copyright and the Supposed Efficiency of First-Degree Price Discrimination (2002) (working paper); Michael J. Meurer, Copyright Law and Price Discrimination, 23 CARdozo L. Rev. 55 (2001). However, as summarized by Richard Posner:

Perfect price discrimination would bring about the same output as under competition, because no customer willing to pay the seller's marginal cost would be turned away. But perfect price discrimination is infeasible, and imperfect price discrimination can result in a lower or higher output than under competition, or the same output. See F.M. SCHERER \& DAVID ROSS, MARKET Structure and Industrial Performance 494-96 (3d ed. 1990); Paul A. SAMUELSON, FOUNDATIONS OF ECONOMIC ANALYSIS 42-45 (1947); JOAN ROBINSON, THE ECONOMICS OF IMPERFECT COMPETITION 188-95 (1933). Many economists believe that even crude discrimination is more likely to expand than to reduce output, see, e.g., ROBINSON, supra, at 201; SCHERER \& ROSS, supra, at 494-96; Peter O. Steiner, Book Review, 44 U. CHI. L. REV. 873, 882 (1977), but there does not appear to be a firm basis for this belief. See Hal R. Varian, Price Discrimination, in HANDBOOK OF INDUSTRIAL ORGANIZATION, at 597, 629-33 (Richard Schmalensee \& Robert D. Willig eds., 1989).

Richard A. Posner, Antitrust in the New Economy, 68 ANTITRUST L. J. 925,932 n.10 (2001).

215 See, e.g., Robert Nozick, ANARchy, State, And Utopia 26 (1974) (setting forth classical libertarian exposition of the role of the minimalist state as "limited to the functions of protecting all its citizens against violence, theft, and fraud, and to the enforcement of contracts"). For later refinement of the issue see ROBERT NOZICK, THE EXAMINED LIFE 286-87 (1989) ("The 
discussion of the theory of the firm and its ability to save transaction costs. ${ }^{216}$ Others see government as also providing important distributive social justice goals. $^{217}$ Along these lines, the path breaking work by Amartya Sen that formed part of the basis for which he was awarded the 1998 Nobel Prize in Economics ${ }^{218}$ elaborates methods for aggregating values across different individuals and offers important hope for improving welfare distributions through social choice. ${ }^{219}$ While there is of course an extensive literature beyond the scope of this article on the theory of government, it is sufficient for the present purpose to highlight some lessons on government from the field of NIE.

In addition to the many important strengths of government mentioned above, just like markets, governments may also have weaknesses (government failures). And just like for markets, each of the problems explored in the sections above and below can be, and often is, viewed as a type of government failure. For example, just as the transaction costs of the market include the costs of bargaining over property rights and striking and enforcing contracts, as well as the costs of professional lawyers and accountants to help with these processes, the transaction costs of the political process include the costs of striking and enforcing political deals, as well as the costs of professional lobbyists, and

libertarian position I once propounded now seems to me seriously inadequate ...."). See also, Milton Friedman, CAPITALISM AND FREEDOM 25-32 (1962) (emphasizing that the role of the government can be justified not as a tool for protecting rights in and of themselves but as a tool for protecting rights as a method for solving collective action problems).

216 For more on transaction costs and the roles of hierarchy see supra Part II.B.2 (discussing transaction costs including the transaction cost saving benefits of hierarchy) and Part II.B.3 (discussing the agency costs and other costs of hierarchy).

217 See generally, JoHn RAWLS, A THEORY OF JUSTICE (1971) (elaborating a view that justifies a more expansive role of government to protect the disadvantaged). To be sure, there are many important views on distributive and redistributive justice that are beyond the scope of this article. Some of these relate rather closely to NIE. For example, one take on the views of government by some including those in the critical legal studies movement is that it inevitably has redistributive qualities to it and because those have been controlled by subordinating groups to the detriment of subordinated groups they have inevitably redistributed from the subordinated to the subordinating. For a recent take on anti-subordination see Christoper A. Bracey, Adjudication, Antisubordination, and the Jazz Connection, 54 ALA. L. REV. 853 (2003) (exploring the antisubordination principle and collecting sources). See also Nancy C. Staudt, The Hidden Costs of the Progressivity Debate, 50 VAND. L. REV. 919 (1997) (pointing out that any theory of government must provide for its funding and elucidating tax policy implications of various theories of government). The NIE literature's take on these perspectives is to elucidate the problems of rent seeking and collective choice.

218 See, Press Release: The Sveriges Riksbank (Bank of Sweden) Prize in Economic Sciences in Memory of Alfred Nobel for 1998, available on line at http://www.nobel.se/economics/laureates/1998/press.html.

219 See, e.g., Amartya K. Sen, Collective Choice and Social Welfare (1970). 
political parties to help with these processes. ${ }^{220}$ In addition, it is often overlooked that the transaction costs of government also include administrative costs, or the costs of administering particular government processes. ${ }^{221}$ As another example, while behavioralism problems can plague those negotiating over property rights and contracts, they can also plague legislators, administrators, and judges. ${ }^{222}$ Put differently:

Just as in the private sector, these governmental undertakings have to bear search and information costs, the costs of decision making, the costs of giving (official) orders, and the costs of measuring, monitoring, creating, and enforcing the observance of official instructions. ${ }^{223}$

In addition, the information and transaction cost problems facing individuals in government may be even greater than those facing individuals in the market. ${ }^{224}$ As North points out, referring to one type of information costs the information needed to engage in exchanges - the intuition behind this lesson is that in government it is "extraordinarily difficult to measure what is being exchanged - promises for votes." 225 According to North, when discussing efficient markets: "[s]uch markets are scarce enough in the economic world and even scarcer in the political world.",226

220 See generally, FURUBOTN \& RICHTER, supra note 20, at 47-49 (summarizing political transaction costs) (citing MANCUR Olson, JR., THE LOGIC OF COLlECTIVE ACTION: PUBLIC GOODS AND THE THEORY OF GROUPS 46 (1965).

221 These costs include the costs of obtaining the information needed to carry out these processes, the costs of behavioralism by those charged with carrying out these processes, as well as the transactions that occur when they are attempted to be carried out. In addition, just as transaction costs of the market include the costs of transactions that are efficient but that fail, the transaction costs of government administration include the costs of failed processes that should have been successful.

222 Kieff, supra note 14, at 1730 (pointing out in the context of IP that government actors also experience behavioralism problems most often discussed in the context of market actors and that in addition they experience the public choice problems discussed in this Part, and citing Paredes, supra note 70, at 461-2 (same, but in the context of securities law, and collecting sources)).

223 Furubotn \& Richter, supra note 20, at 47. See also, MARgAret Levi, Of RUle AND REVENUE, 12 (1988) (noting as political transaction costs "the costs of measuring, monitoring, creating, and enforcing compliance").

224 FURUBOTN \& RICHTER, supra note 20, at 22 ("transaction costs associated with political markets are high, and for this reason institutional inefficiency tends to persist") (citing DoUGLASS North, Institutions, Institutional CHANGE, AND ECONOMIC PERFORMANCE, supra note 190 at 52).

225 North, Institutions and Credible Commitment, supra note 136, at 18.

226 North, Institutions, Institutional CHANGE, AND ECONOMiC PERFormance, supra note 190 at 51. 
But there is another important information cost associated with government. This is the problem of obtaining information about whatever particular activity the government is acting upon in any given setting - legislative, regulatory, or judicial, such as health, safety, the environment, efficiency, welfare, or even what exactly the facts are in any given case. As Haddock points out, "[o]ne crippling bureaucratic disadvantage is that many external costs and benefits are subjective and thus knowable only to the demander or supplier, while the links from production to consumption skirt formal markets where objective proxies might be observed." 227 While instead the government certainly can simply ask individuals what they want and feel in the hope they will reveal such subjective information accurately, as Haddock notes "survey respondents do not put their money where their mouths are, and often return either zero or unrealistically high valuations with little variation across a wide range of amenities, in addition to cross-amenity comparisons that are inconsistent, intransitive, or sensitive to query order and wording.",228

These problems facing government including information costs and transaction costs are several, and are generally known under the field of "public choice," or "collective choice."229 As noted by Richard Epstein, "modern public choice literature postulates self-interest to all political players, and asks how they respond to the incentives created by the rules of the political game." 230

At bottom, in addition to those problems explored elsewhere in the paper, public choice problems also include the particular difficulties government actors executives, legislators, regulators, and judges - have in determining exactly what the public really wants the government to do. That is, public choice problems include the general difficulties in assessing the information content of votes such as their limited ability to fully reflect intensity of preferences, to be fungible, as well as what are generally known as interest group politics, agency capture, etc, as discussed below.

227 Haddock, supra note 114, at 9-10 (citing Friedrich A. von Hayek, The Use of Knowledge in Society, 35 Am. Econ. REV. 529 (1945)).

228 Id. at 10, (citing Matthew D. Adler \& Eric A. Posner, Implementing Cost-Benefit Analysis When Preferences Are Distorted, 29 J. LeGAL STUD. 1105 (2000))

229 For an excellent review of the field see, e.g., PERSPECTIVES ON PUBLIC CHOICE (Dennis C. Mueller ed., 1997); Dennis C. Mueller, Public ChOICE II 232 (1989); Maxwell L. Stearns, PuBLIC Choice And Public Law (1997); Mark Kelman, On Democracy-Bashing: A Skeptical Look at the Theoretical and "Empirical" Practice of the Public Choice Movement, 74 VA. L. REV. 199 (1988); Dwight R. Lee, Politics, Ideology, and the Power of Public Choice, 74 VA. L. REV. 191 (1988); Jonathan R. Macey, Transaction Costs and the Normative Elements of the Public Choice Model: An Application to Constitutional Theory, 74 VA. L. REV. 471 (1988); Maxwell L. Stearns, The Misguided Renaissance of Social Choice, 103 YALE L.J. 1219 (1994).

230 Richard A. Epstein, The Perils of Posnerian Pragmatism, 71 U. CHI. L. REV. 639, 652 (2004) 
Concerning intensity of preferences, while in a market the mechanism of price provides a finely grained mechanism for expressing intensity of preferences, votes in a political system do not convey similarly fine-tuned expressions of intensity of preferences. In the U.S., for example, when an individual casts a vote in a national election the individual is only able to elect whether to cast that vote, or not. The individual cannot cast a smaller or larger vote. Indeed, this is why the technique of cumulative voting is offered as alternative voting system mitigating this effect. As Lani Guinier describes:

Under cumulative voting, voters get the same number of votes as there are seats or options to vote for, and they can distribute their votes in any combination to reflect their preferences. Like-minded voters can vote as a solid bloc or, instead, form strategic, cross-racial coalitions to gain mutual benefits. The system is emphatically not racially based; it allows voters to organize themselves on whatever basis they wish. ${ }^{231}$

Concerning fungibility, while in the market the fungibility of money and many other resources allows them potentially to be spent on various competing uses, votes within the political system can only be spent on the few items on the ballot at any given time and indeed efforts to make them more fungible by, for example, offering them for sale, are strongly discouraged. As Kathleen Sullivan has pointed out:

Literal vote-buying is regarded as a paradigm instance of undemocratic conduct. We no longer countenance gifts of turkeys or bottles of liquor to voters on election day, nor the counting of dead souls. These qualities of voting distinguish the electoral sphere from the marketplace, where goods and services, unlike votes, are fungible, commensurable, and tradable. ${ }^{232}$

Put simply, the increased fungibility of price over voting helps price develop greater information about relative preferences than voting.

Finally, the institution of government is well known even to lay people to be afflicted with the problems of interest group politics ${ }^{233}$ and agency capture. ${ }^{234}$

231 LANI GUINIER, THE TYRANNY OF THE MAJORITY: FUNDAMENTAL FAIRNESS IN REPRESENTATIVE DEMOCRACY 14-15 (1994).

232 Kathleen M. Sullivan, Political Money and Freedom of Speech, 30 U.C. DAVIS L. REV. 663, 671 (1997).

233 For more on interest group politics see Gary S. Becker, Public Policies, Pressure Groups, and Deadweight Costs, in THE ESSENCE OF BECKER, supra note 38, at 544 (presenting model of competition among interest groups and showing that "an increase in the deadweight cost of taxation encourages pressure by taxpayers, while an increase in the deadweight costs of subsidies discourages pressure by recipients").

234 For more on agency capture see Thomas W. Merrill, Capture Theory and the Courts: 1967-1983, 72 CHI.-KENT L. REV. 1039, 1050-52 (1997). 
As described by George Stigler in the path-breaking work that formed in part the basis for which he was awarded the 1982 Nobel Prize in Economics: ${ }^{235}$

\begin{abstract}
Particular industries and occupations obtain from the state a variety of economic privileges which are injurious to the vast majority of the population. Farm subsidies, oil import quotas, tariffs, and occupational licensing are examples. These small minorities achieve their effectiveness primarily because it is uneconomic for the majority to oppose them. ${ }^{236}$
\end{abstract}

In part, therefore, the agency capture problem, also sometimes called regulatory capture, is one of low incentives due to diffuse costs on the part of the public on the one hand and high incentives due to concentrated benefits on the part of the beneficiaries of the agency capture. In part this may be seen as a form of rent dissipation by those seeking the government benefit. Indeed, this link between what is essentially lobbying and rent seeking was first elaborated in the path-breaking work by James Buchanan and Gordon Tullock, ${ }^{237}$ which formed in part the basis for which Buchanan was awarded the 1986 Nobel Prize in Economics. ${ }^{238}$ The basic concept is that the "competition for government favors ... involves a wastage of resources in (unproductive) lobbying activities, bribes, legal fees, and so on.",239

In addition, as elucidated in the path breaking work by Fred McChesney and Hernando de Soto, to the extent the beneficiaries include the government actors themselves, who might for example, enjoy enhanced political contributions or political power (depending in part on whether they are elected or appointed), then the problem can also be seen as one form of the principal agent problem in which the official is the agent of the public and is pursing its own goals instead of

235 See, Press Release: The Sveriges Riksbank (Bank of Sweden) Prize in Economic Sciences in Memory of Alfred Nobel for 1982, available on line at http://www.nobel.se/economics/laureates/1982/press.html.

236 George J. Stigler, Economic Competition and Political Competition, 117, 125 in THE Essence OF STIGLER (Kurt R. Leube and Thomas Gale Moore, eds. 1986) (citing George J. Stigler, The Theory of Economic Regulation, 2 BELl J. EcON. \& MGM’T. ScI. 3 (1971)). See also, David B. Spence \& Frank Cross, A Public Choice Case for the Administrative State, 89 GEO. L.J. 97, 105 n.37 (2000) (collecting sources and describing two variants of capture: one they attribute to the formation of "subgovernments" along the lines outlined by Stigler and another that is slightly different in which the general public is seen to lose "interest in agency policymaking, leaving only regulated interest groups to participate in the process").

237 See, e.g., James M. Buchanan \& Gordon Tullock Calculus of Consent (1962); TOWARDS A THEORY OF A RENT-SEEKING Society (James M. Buchanan, Robert D. Tollison \& Gordon Tullock eds., 1980). For more on rent seeking and rent dissipation see supra Part II.A.2.

238 See, Press Release: The Sveriges Riksbank (Bank of Sweden) Prize in Economic Sciences in Memory of Alfred Nobel for 1986, available on line at http://www.nobel.se/economics/laureates/1986/press.html.

239 FURUBOTN \& RiCHTER, supra note 20, at 479. 
those of the public. ${ }^{240}$ Under this view, "the problem then, is how principals in the form of ... taxpayers can protect themselves against opportunistic behavior on the part of their agents (the policy authorities). ${ }^{241}$ This problem is referred to as the tollbooth view by Simeon Djankov, Rafael La Porta, Florencio Lopez-DeSilanes, and Andrei Shleifer. ${ }^{242}$ What is perhaps more troubling, is that even when those within an agency experience periods of underuse, there will be a tendency for the agency to take on additional missions regardless of whether they are socially desirable. As Milton Friedman, who was awarded the 1976 Nobel Prize in Economics, ${ }^{243}$ explains:

The general rule is that government undertakes an activity that seems desirable at the time. Once the activity begins, whether it proves desirable or not, people in both the government and the private sector acquire a vested interest in it. If the initial reason for undertaking the activity disappears, they have a strong incentive to find another justification for its continued existence.

$* * *$

Again, let me emphasize, the problem is not that bureaucrats are bad people. The problem, as Marxists would say, is with the system, not with the people. ${ }^{244}$

What is perhaps striking is that recent empirical study of entry regulation in 85 countries including the United States by Simeon Djankov, Rafael La Porta, Florencio Lopez-De-Silanes, and Andrei Shleifer confirms both the extent and nature of the capture problem. As they point out:

240 See, Fred S. McChesney, Rent Extraction and Rent Creation in the Economic Theory of Regulation," 16 J. LEGAL. STUD. 101 (1987) (elucidating that politicians and bureaucrats use legislation, regulation, and their threat both to create rents and to extract them through campaign contributions, votes, political favors, or even bribes). See also, Fred S. MCCHESNEy, Money FOR Nothing: Politicians, Rent Extraction, AND POlitical EXTORTiOn (1997) (same, and collecting sources); HeRnANDo DE Soto, THE OTHER PATH (1990) (same). For more on the principal agent problem see supra Part II.B.3.

241 FURUBOTN \& RICHTER, supra note 20, at 23.

242 Simeon Djankov, et al., The Regulation of Entry, 117 Q. J. ECON. 1, 3 (2002 (empirical data showing existence and extent of the problem).

243 See, Press Release: The Sveriges Riksbank (Bank of Sweden) Prize in Economic Sciences in Memory of Alfred Nobel for 1976, available on line at http://www.nobel.se/economics/laureates/1976/press.html.

244 Milton Friedman, Why Government is the Problem, Hoover Institution Essays on Public Policy (1993), 1, 7-13:

This text leaves me two tasks: one easy, one difficult. The first task is to demonstrate that government is the problem; that's the easy task. The hard task is to understand why government is the problem. Why is it that able, publicspirited people produce such different results according to whether they operate in the political or economic market? Why is it that if a random sample of the people who read this essay and are not present in Washington were to replace those who are in Washington, our policies would likely not be improved? This is the real puzzle for me. 
[Public interest theory of regulation would predict regulation to be associated with] higher quality of goods, fewer damaging externalities, and greater competition. Public choice theory, in contrast, predicts that stricter regulation is most clearly associated with less competition and higher corruption. ${ }^{245}$

In concluding their report of the data showing decreased public benefits and competition and increased corruption, they note that " $[\mathrm{t}] \mathrm{his}$ evidence is difficult to reconcile with public interest theories of regulation but supports the public choice approach, especially the tollbooth theory that emphasizes rent extraction by politicians." 246 Such rent extraction implicates both the cost of rent-seeking caused by the option of a particular legal result, ${ }^{247}$ as well as any improper restrictions on freedom of contract and exchange imposed by such a law. ${ }^{248}$ In the final analysis, the central question to be explored when deciding whether to put a particular activity under government control is the relative "adaptive capabilities of institutions such as markets or hierarchies.",249

\section{Property Rights and Common Tragedies}

The final institution on which this paper places special focus is the institution of property rights. As discussed earlier, property rights may provide some of the coordination benefits of a firm without requiring the entire institutional structure of a firm. ${ }^{250}$ By avoiding the degree of hierarchy associated with a firm, property rights can have fewer of the costs associated with the firm. For example, the degree of asset specificity and opportunism can be less because the amount of lock-in or investment in the relationship can be less when contracting over a property right than with the full process of joining a firm. ${ }^{251}$ Similarly, while contracting over the property right will require transaction costs, the ability to strike those contracts on the open market gives more information about opportunity costs and increases the number of potential evaluators, both of

245 Djankov, et al., supra note 242, at 4.

246 Id. at 35.

247 James M. Buchanan, Rent Seeking and Profit Seeking, in JAMES M. BUCHANAN ET AL., TOWARD A THEORY OF A RENT-SEEKING SOCIETY, 359-67 (1980) (exploring rent seeking effects).

248 James D. GWARTNEY, ET AL., ECONOMIC FrEEDOM OF THE WORLD: 1975-1995 (1995) (comparative study of the effects of reduced economic freedom).

249 FURUBOTN \& RICHTER, supra note 20, at 24 (internal citations omitted) (citing (Friedrich von Hayek, The Use of Knowledge in Society, 35 AM. ECON. REV. 519 (markets)) and (CHESTER I. BARNARD, THE FunCTIONS OF THE EXECUTIVE, 30th Anniversary Edition (1968) (hierarchies)).

250 See supra notes 144-146, 163-171, and 173-178, and accompanying text (exploring property rights in the context of the tradeoff between market and firm).

251 See supra notes 125-126 and accompany text (discussing problems of asset specificity and opportunism), and text accompanying note 192, supra (discussing the role of public enforcement of property and contract rights in avoiding the need for a integration within a firm). 
which can mitigate some of the information costs discussed earlier. ${ }^{252}$ Indeed, as Henry Smith has pointed out, property rights, including IP, can even be structured so that they impose sufficiently modest information processing costs on third parties who must evaluate and understand them enough to respect them by avoiding infringement. ${ }^{253}$

At bottom, property rights achieve a type of private ordering via what may be seen as a type of middle ground between the open market on one hand and the hierarchy of the firm on the other hand. This view of the role of property rights elucidates territory that although suggested by different lines of the literature has thus far escaped direct attention. As a foil to the firm, much of the literature on the open market has focused on contractual arrangements among individuals without focusing on the specific rights over which those contracts will be struck; indeed often simply assuming the existence of such rights. The view offered here differs from that line in the literature in suggesting that the creation of specific property rights - in this case IP rights - may help achieve some of the coordination function that is usually ascribed to the firm, without the full integration associated with the firm.

Finally, several special cases of property rights have attracted particular attention in the literature. These include what are called public goods, the tragedy of the commons and the tragedy of the anticommons, which are each discussed below.

\section{(a) Public Goods and Commons}

The subject matter protected by IP can be thought of as information, and indeed when writing about patents Arrow described what is often known as the inventor's paradox or the Arrow Information Paradox, as mentioned earlier in the discussion of information costs generally. ${ }^{254}$ The inventor's paradox is due largely to certain features that are shared by all forms of information in general. Information is a special type of economic good, often called a public good, as distinct from so called private goods, in that it is both nonrival (i.e.,

252 See supra Part II.A.3 (discussing information costs).

253 Henry E. Smith, The Language of Property: Form, Context, and Audience, 55 STAN. L. REV. 1105, 1108, 1114-15 (2003) ("If everyone in the world is expected to respect an owner's right to Blackacre, the content of that right cannot be too complicated or idiosyncratic without placing a large burden on many third parties.") ("the correlation between extensiveness of the audience and mandated unintensiveness of legally significant communication holds in a variety of areas beyond land law, including patent law, copyright law, and innovative forms of intellectual property such as that suggested by the approach of the Supreme Court in International News Service v. Associated Press")

254 See supra notes 60-61, and accompanying text (discussing the Arrow Information Paradox, which is that "its value for the purchaser is not known until he has the information, but then he has in effect acquired it without cost"). 
inexhaustable) and nonexclusive. A good is considered to be nonrival if consumption by one individual does not leave any less of the good to be consumed by others. ${ }^{255}$ A good is nonexclusive if people cannot be excluded from consuming it. National defense, television signals, and police protection are generally considered to be further examples of public goods. ${ }^{256}$ The two distinctive features of public goods - nonrival and nonexclusive - suggest that public goods will tend to be under produced, or not produced at all because of what some call a "free rider problem.",257

Free rider problems are not unique to public goods and indeed also can occur anytime an asset is left open to common access. The generalized statement of the problem of open access was elucidated in the seminal work by Garrett Hardin on what he termed the "tragedy of the commons.",258

But the free rider problem for both public goods and for commons also can be seen as merely an example of positive externalities, as discussed earlier. ${ }^{259}$ And as discussed earlier, there are a number of reasons to think that many externalities turn out to be irrelevant. ${ }^{260}$ For example, in the case of an inventor facing the inventor's paradox and wanting to fund further development of the invention, strategic trading in financial markets may prove sufficient. ${ }^{261}$ That is, the price for goods that would be needed as production inputs for the invention

255 Put differently, a good is considered to be nonrival if for any given level of production, the marginal cost of providing it to an additional consumer is zero.

256 For a more detailed discussion of public goods and the market failures associated with them, see Robert COOTER \& ThOMAs Ulen, LAw And ECONOMICS, at 46-49, 108-119, and 134141 (1988); Robert S. PindyCK \& DANiEl L. Rubinfeld, Microeconomics, 617-641 (1989); Brian R. Binger \& ElizABETH HOFFMAN, Microeconomics With CALCUlus 99-102, 556-585 (1988).

257 U.S. Congress, OfFice of TeChnOlogy Assessment, Finding A BALANCE: Computer Software, Intellectual Property And the Challenge of TeChnological Change 185 (1992) ("Indeed, individuals have an incentive not to pay for the good, or to undervalue it, in hopes of getting access as 'free riders.' The inability to exclude free riders distorts market signals and is thought to result in inefficient allocation of resources to nonexclusive goods and underproduction of them, relative to socially optimal quantities"). See also, MANCUR OLSON, THE Logic of Collective Action: Public Goods AND The TheOry of Groups 43-52 (1971) (elucidating how small, defined groups are the most likely to overcome the transaction costs and free-rider problems raised by public goods);

258 Garrett Hardin, The Tragedy of the Commons, 162 SCIENCE 1243 (1968) (elucidating how unrestricted sharing of limited resources can lead to their over use and depletion). See also, The Commons, Its Tragedies And Other Follies, (Tibor R. Machan, ed., 2001) (providing critical review of literature on the "tragedy of the commons").

259 See supra Part II.B.1 (discussing externalities).

260 See supra notes 114-117 (discussing the irrelevance of inframarginal externalities).

261 See, Jack Hirshleifer, The Private and Social Value of Information and the Reward to Inventive Activity, 61 AM. ECON. REV. 561, 572 (1971) (suggesting just such a strategy, but in addition to reliance on patents). 
(like raw materials) would likely increase if the invention became a commercial success while, conversely, the price for goods that would compete with the invention but are more expensive would likely plummet. Indeed, after Stanley Pons and Martin Fleischmann announced (erroneously) that had discovered cold fusion, Forbes magazine reported:

It sounds too good to be true: an almost limitless source of clean, inexpensive power from a scientific breakthrough which, if fully confirmed, will be as important as the discovery of fire.

Two chemists working at the University of Utah have announced a simple benchtop device which, they claim, produces a thermal output of 4.5 watts on an input of just 1 watt. The scientists, Stanley Pons and Martin Fleischmann, believe the heat arises from nuclear fusion. Laboratories all over the world have been rushing to confirm the experiment, with mixed results.

The Utah discovery is still a very long way from a commercially usable device. But speculators can't wait for scientific proof. They're laying bets now, in, for example, the commodity markets. Because the Utah device uses a palladium electrode, palladium futures have vaulted. One company is making some quick profits selling deuterium to experimenters.

Palladium is the most obvious way to play the cold fusion phenomenon, but there are at least two other metals now known to have potential importance to the process - titanium and lithium. The pure play on titanium, Oregon Metallurgical (OREM), has skyrocketed. An analyst who covers the stock lifted his buy recommendation as it roared through $\$ 15-$ and as I write this, it has crested at $\$ 24$. This is speculation on a speculation: Ignore it. Palladium and titanium are risky because cold fusion may not depend on either one.

Maybe palladium is the secret - but maybe it isn't. For investors who are intrigued by the possibility of cold fusion but don't want to bet too heavily on it, I believe lithium is the best choice. We have ourselves followed this course, because I am strongly convinced that lithium is the essential (and commercially most promising) ingredient in the cold fusion process.

Why lithium? I believe lithium-6 is a source in the cell for tritium (just as it is in the nuclear industry) and that the dominant fusion reaction occurs between this tritium and deuterium. Lithium and its other isotopes, notably lithium-7, are implicated in several alternative interpretations as well.

You can play lithium by investing in the stock of FMC Corp. (My firm bought the stock for customer accounts at $\$ 33$ on Apr. 11.) FMC is a diversified chemical and machinery company that happens to own and produce lithium. It is probably slightly undervalued, so it is thus a fair investment on its other merits. If the cold fusion phenomenon sputters to a dead end - as it certainly could you would be left with FMC holdings with substantial value. One could not say this of palladium futures. ${ }^{262}$

262 Michael Gianturco, A Fusion Flier, Forbes, May 15, 1989. 
Indeed, properly timed trades in palladium futures would have yielded substantial profits even though it was ultimately determined that Pons' and Fleischmann's cold fusion turned out actually not to work, which did not seem to be lost on at least Pons:

B. Stanley Pons.... He has a wry sense of humor. Asked in Dallas if a cheaper substitute metal for the rare palladium could be used to generate the same effect in his experiment, he replied: "I refuse to say until I sell my futures." 263

To be sure, the trading of commodities futures is not the only tool for making irrelevant the positive externalities of inventions and other information goods. ${ }^{264}$ Direct government subsidy is another option, and indeed this is done in the case of many areas of basic science. ${ }^{265}$ But this is not the only form of government action that is available. In addition, subsidies only give individual

263 Chris Black, Pons A “Little Nerdy” Maybe, But He Gives Great Parties, THE BostON GloBE, April 17, 1989. For more about market pricing behavior see BURTON MALKIEL, A RANDOM WALK DOWN WALl STREeT (1996).

264 Indeed, it may not be a legally prudent strategy for inventors to rely on this option. Nor may it be socially desirable. After the Supreme Court decision in U.S. v. O'Hagan applying the misappropriation theory of insider trading, liability might attach to the trading of securities based on information obtained in breach of a fiduciary duty, whether in the strict insider sense or not. See U.S. v. O'Hagan, 521 U.S. 642 (1997) (extending liability under Section 10(b) of the Securities Exchange Act to be predicated under "misappropriation theory"). For more on the misappropriation theory see Richard W. Painter, et al., Don't Ask, Just Tell: Insider Trading after United States v. O'Hagan, 84 VA. L. REV. 153 (1998); Kimberly D. Krawiec, Fairness, Efficiency, and Insider Trading: Deconstructing the Coin of the Realm in the Information Age, 95 Nw. U. L. REV. 443 (2001). In the case of a scientist inventor trading on the basis of information about his own invention the easy insider case before O'Hagan would be if the invention were made within the scope of his employment and so the information might be viewed as being owed by his employer and its use for the personal profit of the inventor would be trading on insider information. But after O'Hagan, which expands the liability to include broader types of misappropriation, the scientist inventor might be viewed to be breaching some kind of fiduciary duty to the one funding the science - perhaps the government - or even to science at large in the way other professionals are viewed as owing duties associated with professional ethics. To be sure, this last view of a duty to science at large would require that the norms of science be considered by a court to be so dictated by prescriptive norms. But there is at least some debate as to whether the norms of science are so strongly prescriptive, or merely aspirational. Compare, Rai supra note 186 (arguing the norms are both descriptive and prescriptive) with Kieff, supra note 185 (arguing that the norms are more aspirational).

265 See, e.g, Michael Polanyi, Patent Reform, 11 ReV. Of Econ. STUDIES 61, 65 (1944) (discussing the option of direct government subsidy). Indeed this is the option Pigou offered to solve the problem of positive externalities and that Coase was criticizing responding in his famous article on the problem of social cost. See supra notes 101-106, and accompanying text. 
rewards, which for many reasons may not be effective, and yet they fail to facilitate coordination. ${ }^{266}$

Property rights can provide a middle ground between the two extremes of atomized free market acting within the context of an open commons on the one hand and total government production on the other hand. ${ }^{267}$ Michael Heller, building upon earlier work by Armen Alchian and Harold Demsetz, provides the example of a hypothetical community called "Poach Pond" in which underfishing of the pond may occur if the rule were that any community member could appropriate fish until the moment of consumption because people might prefer to wait on shore and poach others' catches rather than invest in fishing itself. ${ }^{268}$ As Demsetz pointed out in his seminal work on the emergence of property rights, property rights may serve as a tool for internalizing externalities. ${ }^{269}$ And as Coase pointed out, this can be used as a tool in place of direct Pigouvian subsidy. ${ }^{270}$

Indeed, the free rider, tragedy of the commons, and positive externalities problems each can be thought of essentially as an inverse of the problem of rent dissipation, discussed earlier. ${ }^{271}$ Whereas the problems of free riding, commons, and positive externalities, refer to cases in which individuals within a group decide not to invest in a given activity for fear that others will benefit but not compensate and as a result too little of the activity is produced, the problem of rent dissipation refers to a case in which individuals within a group decide to invest in a given activity for fear that others will do the same and win the race for the common prize and as a result too much of the activity is produced. In both sets of cases, the failure to coordinate leads to inappropriate amounts of the given activity being produced. The connection between these two classes of problems

266 For more on the failures of reward theories and the strengths of coordination theories for property rights in the context of IP see infra Part III.

267 This is a different middle ground view of the role of property rights than the one explored earlier between the open market and the firm. See supra notes 144-146, 163-171, 173-178, and 250 , and accompanying text (exploring property rights in the context of the tradeoff between market and firm).

268 Michael A. Heller, The Tragedy of the Anticommons: Property in the Transition from Marx to Markets, 111 HARV. L. REV. 621, 675 (1998). See also, Armen A. Alchian \& Harold Demsetz, The Property Rights Paradigm, 33 J. ECON. HIST. 16, $23-24$ (1973) (providing the example of a community in which food caught in a hunt for animals may be shared by all and the resulting diminished incentive for individuals in that community to elect to hunt, or in his words "shirk," absent other inducements such as a state order to hunt or a cultural indoctrination to hunt).

269 See supra notes 107, 173-178, and accompanying text.

270 See supra note 103, and accompanying text.

271 See Terry Anderson \& Peter J. Hill, Privatizing the Commons: An Improvement?, $50 \mathrm{~S}$. ECON. J. 438, 441, 447 (1983). For more on rent seeking and rent dissipation see supra Part II.A.2. 
based on their common failure of coordination is important because, as discussed earlier, property rights can provide this coordination. ${ }^{272}$

While property rights can have benefits, they of course also have costs. Chief among these are the transaction costs that are needed to create, exchange, manage, and avoid property rights. ${ }^{273}$ Related to these costs are the information costs of determining what the rights are and what value they have, and to whom. $^{274}$ There also can be rent dissipation costs associated with the desire to obtain property rights. ${ }^{275}$ Finally, recent important and innovative work by Michael Heller has spawned a rich literature on a different problem associated with property rights (although often in a mistaken fashion) that he termed the "tragedy of the anticommons," 276 as discussed in the following.

\section{(b) Anticommons, Permit Thickets, and License Raj}

Heller's landmark contribution to the property literature regarding anticommons was originally based on his study of real property in the postsocialist economies of Eastern Europe, but he has also applied it to IP. As described by Heller:

Consider new areas for property law, such as the problem of spurring private investment in biomedical research or creating well-functioning markets in postsocialist economies.... By drawing the wrong property boundaries around resources, by fragmenting ownership too much, it turns out that privatization can destroy resource productivity in enduring ways. To capture these unexpected results from excessive privatization, I have proposed the idea of anticommons property, an image that goes beyond the old trilogy [private, commons, and state] and crystallizes emerging real-world property relations that had previously remained invisible....[A] resource is prone to underuse in a tragedy of the anticommons when multiple owners each have a right to exclude others from a scarce resource and no one has an effective privilege of use. In theory, in a

272 See supra Part II.B.4 (discussing coordination problems generally and the ability for property rights to help solve them).

273 See supra Part II.B.2 (discussing transaction costs).

274 Much of the important recent work on the information costs associated with property rights has been done by Henry Smith. See, e.g., Smith, supra note 163; Merrill \& Smith, supra note 163; and Smith, supra note 253. For more on information costs generally, see supra Part II.A.3.

275 See Anderson \& Hill, supra note 271 (elucidating how the rent seeking costs associated with obtaining property rights can dissipate the gains from creating those rights, and providing case studies). See also, Levmore, supra note 4 (noting that rearrangements of property rights can have the same effect). While in some cases the rent dissipation will be directly through the resources expended to race, in other cases the rent dissipation will also trigger problems of public choice. For more on public choice see supra PartII.C.3.

276 Michael A. Heller, The Tragedy of the Anticommons: Property in the Transition from Marx to Markets, 111 HARV. L. REV. 621 (1998). 
world of costless transactions, people could always avoid common or anticommons tragedy by trading their rights. In practice, however, avoiding tragedy requires overcoming transaction costs, strategic behaviors, and cognitive biases of participants, with success more likely within close-knit communities than among hostile strangers. Once an anticommons emerges, collecting rights into usable private property is often brutal and slow... I developed the idea initially from closely observing privatization in post- socialist economies. One promise of transition to markets was that new entrepreneurs would fill stores that socialist rule had left bare. Yet after several years of reform, many privatized storefronts remained empty, while flimsy metal kiosks, stocked full of goods, mushroomed up on the streets. Why did the new merchants not come in from the cold? One reason was that transition governments often failed to endow any individual with a bundle of rights that represents full ownership. Instead, fragmented rights were distributed to various socialist-era stakeholders, including private or quasi-private enterprises, workers' collectives, privatization agencies, and local, regional, and federal governments. No one could set up shop without first collecting rights from each of the other owners. ${ }^{277}$

Heller seems to suggest that what he terms "fragmentation," or excessive numbers of rights holders, is key to the anticommons effect because the transaction costs of dealing with so many claimants will dominate. ${ }^{278}$

But fragmentation itself is not the key to the anticommons effect that is observed in post socialist economies. What really drives the problem is the lack of what Anderson and Hill call a "residual claimant."279 To provide a brief summary definition at the outset, a residual clamant in the context of the anticommons problem caused by many holders of a right to respond "no" to requests for permission essentially means an individual who is able to extract private value from such a request by electing to respond with a "yes." But to more fully understand the nature of the issue, further elaboration is required.

As Buchanan and Yoon elucidated, there actually exists "a formal symmetry between the overusage of a resource because of common (multiple) access and the underusage because of multiple exclusion rights" 280 In

277 Michael A. Heller, The Dynamic Analytics of Property Law , 2 THEORETICAL INQUIRIES L. 79, 87-89 (2001) (drawing the definition of anticommons property from Heller, supra note 276, and building on the discussion of IP rights from Michael A. Heller \& Rebecca S. Eisenberg, Can Patents Deter Innovation? The Anticommons in Biomedical Research, 280 SCIENCE 698 (1998) [hereinafter Heller \& Eisenberg, Anticommons].

278 See, Heller supra note 276, at 624 (arguing that when too many owners hold rights of exclusion in a resource, the resource is prone to under use). See also, Heller \& Eisenberg, Anticommons supra note 277, at 700; Michael A. Heller, The Boundaries of Private Property, 108 YALE L.J. 1163, 1174-75 (1999).

279 See Anderson \& Hill supra note 271 (using the term "residual claimant" while exploring the related problem of rent dissipation during races for a common prize).

280 See, e.g., James Buchanan \& Yong J. Yoon, Symmetric Tragedies: Commons and Anticommons, 43 J. LAW \& ECON. 1, 12 (2000). For an interesting taxonomy applying this symmetry see, Lee Anne Fennell, Common Interest Tragedies, 98 Nw. U. L. REV. 907 (2004). 
highlighting this symmetry, they then point out that in both cases (commons and anticommons) the heart of the problem can be tied to the nature of the holders of the right (to use or exclude, depending on whether the tragedy is one of commons or anticommons). More particularly, according to Buchanan and Yoon, the problem lies in whether the holders have "noneconomic motivations" in that they are those "who cannot or may not desire to, capture directly pecuniary gains," meaning that their goals may not be "primarily distributional but instead may reflect different objectives." ${ }^{281}$ Indeed, Buchanan and Yoon warn of the potentially pernicious impact in either case (commons or anticommons) of the "genuine zealot...[who] may be insensitive to proffered compensations." ${ }^{282}$ At bottom, the concern Buchanan and Yoon highlight is that the crux of the problem for both commons and anticommons relates to the ability of those engaged in the group activity to coordinate with each other, but when the individuals have noneconomic motivations they are unlikely to so coordinate unless they happen to share some other coordinating attribute, such as being close-knit. ${ }^{283}$

In contrast, as discussed previously, coordination is a central problem studied by NIE and one general response to coordination problems can be property rights. ${ }^{284}$ While at first blush given the way Heller presents the anticommons problem it would seem that property rights are more a part of the problem than a part of the solution, it turns out this just is not so. Property rights provide individuals with the economic motivation to engage in trades with each other. Indeed, the easier it is for the holder of a property right to engage in such a trade and the greater the value that the individual can extract from the trade (the greater the residual claim), the greater the motivation and ability the individual has to engage in it. ${ }^{285}$

What really drives the anticommons problem in the post-socialist economies is both the lack of residual claim and the lack of clarity that are

281 Id. Buchanan \& Yoon (citing the example of an environmental regulator whose permission is needed to put an asset to use but whose permission should not be bought). To be sure, without being motivated by direct pecuniary gains, a regulator may be economically motivated along the lines of the political favors discussed in the public choice literature. See supra Part II.C.3 (discussing public choice).

282 Id.

283 Heller suggests the coordination benefits of being "close knit." See text accompanying note 277, supra. See also supra notes 160-161, and accompany text (discussing the coordination benefits of family and other close personal ties within the context of "crony capitalism").

284 See supra Part II.B.4 (discussing coordination problems and the role of property rights in easing them). See also supra notes 271-272 and accompanying text (focusing on property rights and coordination as a tool for mitigating both commons problems and rent dissipation problems).

285 See R. Quentin Grafton \& Dale Squires, Private Property and Economic Efficiency: A Study of Common Pool Resource, 43 J. L. \& ECON. 679 (2000) (providing empirical data showing how various institutional changes towards the treatment of private property rights as fully tradable assets are essential for facilitating efficient use of common pool resources). 
associated with the pertinent rights of exclusion. ${ }^{286}$ As Richard Epstein and Bruce Kuhlik have recently pointed out in response to the perceived anticommons problem relating to IP, the distinguishing feature of the anticommons in the postsocialist economy is that efforts by the bureaucrats to engage in open trading of their permission for personal gain are likely to trigger various forms of criminal liability for graft, bribery, public corruption, etc. ${ }^{287}$ What is more, in such a sequential bribe situation there is a greater degree of uncertainty that each bribe will either be needed or effective. This is in part because those being bribed can't openly coordinate. It is also because some of those who's permission would be needed might not even be open to being bribed. They might justifiably be steadfastly acting to prevent an activity they see as bad. ${ }^{288}$ Alternatively, they may derive more benefit - perhaps sense of control or power or even just some other kind of perhaps perverse pleasure - from simply being able to say "no" than from what otherwise might be obtained in exchange for saying "yes."289

Put differently, the anticommons problem in the post-socialist environment, indeed just as the anticommons problem in general, is tied to the inability of those who hold rights of exclusion to openly negotiate to extract value for a decision to give reliable permission rather than withhold permission or give faulty permission. At bottom, there is a huge difference between the openly tradable nature of property on the one hand and what Epstein refers to as a pernicious "permit thicket" as in the case of the post-socialist economy on the other hand. ${ }^{290}$ Interestingly, the anticommons problem is not unique to the postsocialist economy and indeed is nicely captured by a well known expression used in India after throwing off British rule, also called "Raj," where it was said that Raj had been replaced by "License Raj" in the form of excessive and unpredictable requirements for permits and licenses from the many branches of

286 The importance of certainty for facilitating private ordering is explored supra notes 198208, and accompanying text.

287 See, e.g., Richard Epstein \& Bruce N. Kuhlik, Navigating the Anticommons for Pharmaceutical Patents: Steady the Course on Hatch-Waxman, Chicago John M. Olin Law \& Economics Working Paper (2d Series) No. 209, at 4 ("But the state bureaucrat is not the owner of any asset whose value will remain unlocked unless he brings it to market"). Nevertheless, individual regulators have incentives to try to extract such value, which explains the results of the empirical study of the public choice "tollbooth" theory of regulation discussed in the text accompanying notes 240-246 supra.

288 This would be consistent with the public interest view of regulation. For more on the public interest theory of regulation see supra text accompanying note 245.

289 Consider for example the well known childhood tease, or prank, sometimes known as "Want a lick?... Psych!" involving the offering a lick of an ice cream cone to a peer and then after inducing anticipation, but before delivery, withdrawing the cone to prevent the lick while exclaiming "Psych!" or some more colorful equivalent.

290 See Epstein \& Kuhlik, supra note 287 (citing Richard. A. Epstein, The Permit Power Meets the Constitution, 81 IowA L. REV. 407 (1995)). 
the central government in order to conduct many important business activities. ${ }^{291}$ At bottom, the essential lesson of anticommons is that it can be seen as a coin having two poisonous sides: the pernicious "permit thicket" or "License Raj" implications for taxing and retarding development on the one hand; and the "tollbooth" implications of extortion by agencies on the other hand. ${ }^{292}$

\section{Wrapping-up Problems Explored through NIE}

The many problems explored above and their interrelationships are quite complex. As a result, the above treatment is necessarily too brief, and therefore in many respects inaccurate. But it is offered in the hope that it sufficiently helps elucidate the general nature of these problems and how they relate to each other to inform the below discussion of the extensive literatures on normative IP theory and positive IP law, which for the most part have relied upon many of these problems in a rather piece-wise fashion.

Before proceeding to a more focused discussion on IP there are a few core lessons that should be drawn from the above treatment. First, on a general level, the details of different institutional choices matter in that they have different implications for a large number of costs and problems. Second, on a very granular level, the treatment above will be used below to show how many of the problems that have attracted attention in the IP literature turn out to be properly viewed as inapposite, overstated, or even having implications opposite of those offered by the literature. Third, on a conceptual level, property rights in general and IP in particular are not offered as perfect solutions to every problem. The case is not being made for property or IP, uber alles.

Rather, the point is that property rights and IP can provide an important additional and middle-ground tool for optional use by individuals engaged in private ordering beyond those offered by the extreme poles of either the free, open market without them on the one hand or the hierarchy of family, firm, or

291 I thank participants in the faculty workshop held at Wolfson College, Cambridge University, June 28, 2004, for pointing out this term to me. For more on the problem of License Raj in India see, e.g., JAGDISH N. BHAGWATI, INDIA IN TRANSITION: FrEEING THE ECONOMY 49-51 (1993) (discussing the system of permits and licenses needed in India for both outside investment and for internal economic development). See also, Emran, M. Shahe, et al., After the "License Raj:" Economic Liberalization and Aggregate Private Investment in India (2003) (available online at http://ssrn.com/abstract=411080) (same); Sunita Parikh \& Barry R. Weingast, $A$ Comparative Theory of Federalism: India, 83 VA. L. REV. 1593, 1608 (1997) ("This system, known in India as License Raj, means that the center retains control over the distribution of permits and licenses for new areas of economic development through the relevant central ministry").

292 See supra notes 240-246, and accompanying text (discussing "tollbooth" theory of regulation in the context of agency capture and public choice). 
government on the other hand. ${ }^{293}$ But, to play this role, IP rights must be designed to facilitate private ordering. To achieve this role effectively, they must operate as rights of exclusion around which coordination can take place. To do so efficiently, they must be structured to mitigate the costs of rent dissipation, information, transactions, and public choice.

As discussed in more detail below, it therefore makes sense as a matter of normative theory for IP rights to be designed to achieve this coordination role. Indeed, other popular normative theories of IP - reward and prospect or rent dissipation - fail to teach how the regimes could be structured to be either effective or efficient in achieving the various goals posited by those theories. ${ }^{294}$ In addition, there are reasons to think that the regimes of patent law and trademark law can be both effective and efficient in achieving this coordination role, while least for the entertainment industry the copyright regime may be neither effective nor efficient in achieving this effect, and indeed may not be needed. ${ }^{295}$

\section{LESSONS FROM NIE FOR LAW \& ECONOMIC THEORIES OF IP}

While the large body of literature involving law and economic theories of IP has taught a great deal about some of the specific issues it explores, this paper objects to the approach of much of that literature as focused too narrowly on only some of the issues explored in the above review of NIE, and too often only in some settings. As discussed more fully below, one central lesson for IP from NIE is that in the real world each of these issues is at play, and often in several different settings. Put differently, each issue must be considered in relation to the others, and all in the context of private ordering as it occurs in the real world over time. At bottom, the views explored here are more consistent with private ordering than those in the literature, which may instead be seen as justifications for various forms of more extensive government regulation. ${ }^{296}$

The overall theme of this paper is that government, law, contracts, property rights, organization, and norms can complement each other to overcome barriers that otherwise prevent the subject matter of IP from coming to market. This stands in contrast to most of the literature on the law and economics of IP, ${ }^{297}$

293 For elaboration on the role of property rights as a middle ground see supra notes 144146, 163-171, 173-178, and 250, and accompanying text (exploring property rights in the context of the tradeoff between market and firm). See also supra note 267(exploring property rights in the context of the tradeoff between market and government).

294 See infra Part III (discussing theories of IP).

295 See infra Part IV(discussing positive law IP regimes).

296 Again, as discussed supra in note 163, the term private ordering is used here in a broader sense than in some of the NIE literature.

297 See infra Part III.A (discussing reward literature). 
which has focused largely on only one of the major obstacles at a time, such as elucidating the transaction costs or monopoly costs of property rights, as part of a larger effort to advocate a shift towards the elimination of property rights in IP to leave what some call greater "open commons" or "public domain."

The approach of this paper differs in considering the set of problems from the NIE literature that are explored above to answer questions about improving the delivery of IP subject matter in the real world. For example, in addition to the transaction costs explored in other works on innovation, this paper also considers those costs without IP rights as well as each of the other problems relating to the individual level, inter-individual level, and institutional level, as explored above. $^{298}$ That is, it performs a more comprehensive comparative institutional analysis of options for bringing ideas to market so as to avoid indulging a nirvana thesis, which would strive towards the theoretical utopia rather than those options available in the real world. ${ }^{299}$

In making this comparative institutional analysis, the paper reveals how the Copyright system fails to offer sufficient coordination benefits, and in addition generates too many costs. ${ }^{300}$ In contrast, patent and trademark do offer appropriate coordination benefits and impose sufficiently few costs. ${ }^{301}$ In addition, the particular coordination benefits offered by patent and trademark may be able to meet any need that otherwise would exist for coordination by copyright, at least in the entertainment industry. ${ }^{302}$ Thus, the paper shows how patent and trademark may obviate the need for copyright in this setting.

\section{A. Problems of Reward Theories and the Incentive Access Paradigm}

The bulk of the law and economics literature on IP regimes in this country focuses on the government's role in providing targeted incentives to specific creative individuals to solve the public goods problem associated with intellectual works while at the same time mitigating the monopoly distortion and transaction costs associated with the IP right to exclude. ${ }^{303}$ The concern driving this

298 See supra Part II (reviewing set of problems explored by NIE).

299 See supra notes 20-31, and accompanying text (discussing comparative institutional analysis).

300 See infra Part IV.A (discussing social costs and benefits of copyright).

301 See infra Part IV (discussing social costs and benefits of patent and trademark).

302 See infra Part IV.B (discussing possible use of patents and trademarks in place of copyrights to facilitate commercialization in the entertainment industry).

${ }_{303}$ See, e.g., Clarisa Long, Information Costs in Patent and Copyright, 90 VA. L. REV. 465, 466 (2004) ("The conventional theory of intellectual property rights posits that such rights exist to stimulate the creation and distribution of intellectual goods") (citing Lemley, supra note 61, at 993 (1997) ("Intellectual property [rights are] fundamentally about incentives to invent and create."). Although there are a number of incentive-based theories for IP that are mentioned in the literature - including "incentive to invent", "incentive to disclose" or "teach," "incentive to innovate," and 
perspective is that the subject matter protected by IP will be under-produced because it is characterized by the Arrow Information Paradox, which is to say it has public good qualities or has positive externalities. ${ }^{304}$ Under this view, incentives to produce are provided through specific rewards for specific creative work. For example, patents are offered as incentive to invent; and copyrights as incentive to generate creative expression. Importantly, the literature does not see rewards merely as some kind of ancillary effect of IP; it sees reward as IP's central goal. What is more, under this view, the reward and its recipient must be carefully regulated to mitigate monopoly effects and transaction costs. ${ }^{305}$ As summarized by Jack Hirshleifer and John Riley when discussing patents, for example, "[t]he central problem considered by modern analysts has been the conflict between the social goals of achieving efficient use of information once produced versus providing ideal motivation for production of information."306 Glynn Lunney has called this conflict, or balance, between incentive and access the "incentive access paradigm." 307

"incentive to design around" - there are essentially three dominant theories today: (1) some version of the "incentive to invent" and "disclose" theories treated together under the rubric of "reward;" (2) the "prospect" theory; and (3) the commercialization theory. For a recent review of the patent literature on incentive theories and a collection of sources see CHISUM, ET AL. supra note 5, at 58-90 (reviewing various incentive theories for the patent system). See also, Rebecca S. Eisenberg, Patents and the Progress of Science: Exclusive Rights and Experimental Use, 56 U. CHI. L. REV. 1017, at 1024-46 (1989) (same); A. Samuel Oddi, Un-Unified Economic Theories Of Patents - The Not-Quite-Holy Grail, 71 Notre DAME L. REV. 267 (1996) (same). For recent reviews of the copyright literature on incentive theories and a collection of sources, see Glynn $\mathrm{S}$. Lunney, Jr., Reexamining Copyright's Incentives-Access Paradigm, 49 VAND. L. REV. 483 (1996) (reviewing and collecting sources and suggesting that incentives may draw efforts away from other productive activities); Michael Abramowicz, Copyright Redundancy, George Mason Law \& Economics Research Paper No. 03-03 (2003) (available on line at http://ssrn.com/abstract=374580 (reviewing and collecting sources and highlighting the opportunity cost issues discussed by Lunney as well as showing how additional works on the margin may contribute little while at the same time causing rent dissipation).

304 For more on public goods problems and the subject matter of IP see supra Part II.C.4(a).

305 See, e.g., Stanley M. Besen \& Leo J. Raskind, An Introduction to the Law and Economics of Intellectual Property, 5 J. Econ. Persp. 3, 8 (1991) ("The patent offers the incentive of the statutory right to exclude as a means for inducing creative activity."). Several types of regulatory responses to IP rights are generally justified by this concern. Examples include liability rule treatment, misuse, fair use, etc.

306 Hirshleifer \& Riley, supra note 53, at 1404 (emphasis in original) (citing Arrow, Economic Welfare and the Allocation of Resources of Invention, supra note 60, and Fritz Machlup, Patents, in 11 InTERnATIONAL ENCYClOPEDIA OF THE SOCIAL SCIENCES 461 (Macmillan, Free Press, 1968)).

307 Glynn S. Lunney, Jr., Reexamining Copyright's Incentives-Access Paradigm, 49 VAND. L. REV. 483 (1996) (reviewing the incentive access-paradigm and highlighting an additional cost of IP is the opportunity cost of deploying resources towards IP that could instead have been deployed elsewhere). 
Although the reward literature contributes much to our understanding of IP, it has a number of serious limitations. One perspective is to see these theories as focusing on the role of government in providing both subsidy and regulation rather than in providing less invasive forms of intervention, such as setting rules and resolving disputes. ${ }^{308}$ That is, the government is seen as needed on the one hand to prop up potential holders of IP and then on the other hand to keep them in check. Another perspective is to see the reward literature as paying too much attention to direct incentives for creators, to monopoly power, and to transaction costs, all on only some settings, while paying remarkably little attention to these same issues in other settings, as well as overlooking a host of other important issues including, for example, coordination problems and public choice problems. $^{309}$

Indeed, the reward theories may be seen as premised on a false perception of tension between incentives and access. Under this view, the inventive side of the paradigm is inapt because IP rights are not and should not be offered to provide direct incentives to invent or create. Similarly, the access side of the paradigm is also inapt because IP rights are more successful than rewards, by design, in facilitating access. These objections to both components of the paradigm are explored in more detail below.

\section{Imprudent Incentives}

The incentive side of the paradigm is inapt because it is not clear that endeavoring to provide direct incentives is even prudent. Put differently, one central objection to reward theories is tied to the problem of rewards themselves. That is, rewards may not be needed, may not be effective, or may have bad sideeffects. Rewards may not be needed to the extent that enough of the desired activity may occur without added incentive of the reward. ${ }^{310}$ Rewards may not be effective to the extent that the desired activity might not be responsive to

308 For a general discussion of the role of government see supra notes 215-219 and accompanying text.

309 For a review of each of these problems see supra Part II.

310 See supra notes 114-117 (discussing the irrelevance of inframarginal externalities). For example, individuals may be driven by self-satisfaction, search for knowledge, reputation, etc. Indeed, although the positive shift in 1980 to allow patents in basic biotechnology did lead to some increase in amount of inventive activity being done in the field, the amount before was still quite substantial. This is not surprising given that in a field with large lumber of people having sufficient creative ability working to solve a problem it is likely the solution will be found. See JACOB SCHMOOKLER, INVENTION AND ECONOMIC GROWTH 215 (1966). For more on the norms of science and the incentive they provide towards discovery see, e.g., Robert K. Merton, The Role of Genius in Scientific Advance, NEW ScIENTIST, Nov. 2, 1961, at 306. 
additional incentive. ${ }^{311}$ Rewards may have bad side effects to the extent that the social costs of investments made to get them may be greater than the social value of the activity rewarded. ${ }^{312}$

A related problem with reward theories is that the correlation between the amount of reward and the merit of the awarded activity is unclear. On the one hand, for example, empirical works by Steven Shavell and Tanguy van Ypersele and by Michael Kremer have shown that at least for patents the patentee often does not receive the full social surplus created by the patented invention. ${ }^{313}$ On the other hand, for example, earlier work by the present author has pointed out the difficulties in developing a theory of just deserts as a basis for government to allocate any reward among potential claimants, whether the reward is a patent or cash. $^{314}$

Understanding the relationship between the reward and the activity being rewarded is important because it would inform determinations about how to set the reward. If set too low, then there may be insufficient positive response. If too

311 This may be because the activity is only responsive to alternative inducements such as self-satisfaction, search for knowledge, reputation, etc. See, e.g., Besen \& Raskind supra note 305, at 6 ("Another critical element in deciding how to strike the balance between encouraging innovation and dissemination is the extent to which creative activity responds to economic rewards. The less that innovation depends on the resources invested and the potential economic rewards, the more limited is the case for granting substantial rights to creators.").

312 This may be because they may trigger rent dissipation. For more on rent dissipation generally see supra Part II.A.2. For more on rent dissipation within the context of IP see infra Part III.B. This may also be because of the opportunity cost associated with the efforts made towards winning the reward. See Lunney supra note 307 (discussing role of opportunity costs).

313 See, e.g., STEVEN SHAVEll \& TANGUY VAN YPERsele, RewARds Versus Intellectual Property Rights 1-8 (National Bureau of Econ. Research Working Paper No. 6956, 1999); See, e.g., Michael Kremer, PATEnt Buy-Outs: A Mechanism for ENCOURAGing INNOVATION 1-5 (National Bureau of Econ. Research Working Paper No. 6304, 1997). Social surplus is the amount of total social welfare generated by the invention minus the costs of making the invention, such as research by the inventor and the inventor's competitors. Social welfare is the aggregate value of all utility that individuals obtain from the invention.

314 See Kieff, Commercializing Inventions, supra note 8, at 713-14, n. 77 (citing LEO KATZ, Ill-GotTen GAINS: Evasion, BLACKMAIL, AND KINDRED PUZZLES OF THE LAW 200 (1996)). As pointed out when discussing the problem of two or more authors or inventors:

Concerning the distinction between acts and omissions, one might ask what level of contribution is required on the part of a supervising faculty member for co-authorship or co-inventorship. What is sufficient: active advice, or passive permission and non-interference where others would have refused to allow a project, or its continuance? Also consider how the rules of praise should evaluate the problems presented by cases of mere thought, transferred intent, or unreasonable hopes; any of which might nonetheless correlate with inventive success. To what extent should originality, effort, genius, or utility drive our decisions to allocate rewards?

Id. (citations omitted). 
great, the marginal excess may generate too little marginal positive response or may generate too many negative side effects. ${ }^{315}$ While simple metrics such as too big or too small may turn out not to matter, at least some dimension of the reward will matter and yet the reward theories offer no guidance as to how to set the reward along that dimension, whatever it may be. ${ }^{316}$

Some of the reward theorists do suggest techniques for solving some of the problems of determining the reward while at the same time mitigating the monopoly power and transaction costs problems associated with the IP property right by suggesting as alternatives to IP rights various forms of cash reward, prize, buyout, or subsidy. ${ }^{317}$ To be sure, these reward or prize proposals are each more ingenious than the other in developing methods for finding, at least on average and in theory, the "right" price for rewards. And while Michael Abamowicz provides extensive and thoughtful analyses of many of their shortcomings, for several of these he also provides potential solutions. ${ }^{318}$ Nevertheless, in the final analysis the best case for these proposals leaves them as adjuncts to the IP system, not as complete replacements, ${ }^{319}$ and so their availability does not supplant the

315 For example, too little positive response might occur because those responding to the rewards might have decreasing marginal desire or ability to respond. Similarly, for example, too many negative side effects might occur if the opportunity costs of the resources being spent responding are too high or if their rent seeking costs are too great.

316 This problem is described as "screening" in earlier work by the present author and its resolution is one of the strengths of the commercialization theory, and its companion registration theory: these theories turn out to have great explanatory power for the positive law rules governing when valid IP rights are available. See, Kieff, Registering Patents, supra note 8 (elucidating the normative case for these positive law rules for patents). For more on these positive law rules see infra Part IV.

317 For an excellent review of these proposals including in-depth critiques see Michael Abramowicz, Perfecting Patent Prizes, 56 VAND. L. REV. 115 (2003). For convenience, these proposals can be summarized in very brief form as follows: (1) patents are bought out by the government with prices informed by test marketing (Robert C. Guell \& Marvin Fischbaum, Toward Allocative Efficiency in the Prescription Drug Industry, 73 MILBANK Q., June 1995, at 213); (2) awards are given in the place of patents with the amount of reward set by later developed data from actual demand (SHAVELL \& TANGUY VAN YPERSELE, supra note 313); (3) patents are bought out with prices informed by probabilistic auctions (KREMER, supra note 313); (4) subsidizing purchases of subject matter covered by patents as a tool for improving effectiveness of price discrimination by patentees (Douglas Gary Lichtman, Pricing Prozac: Why the Government Should Subsidize the Purchase of Patented Pharmaceuticals, 11 HARV. J.L. \& TECH. 123 (1997)); and (5) the use of retrospective prizes in exchange for efforts to decrease monopoly effects of patents (Abramowicz, Perfecting Patent Prizes).

318 See Abramowicz, Perfecting Patent Prizes, supra note 317.

319 See, e.g., Id., at 115 (ultimately concluding that its proposal "would complement rather than replace the patent system"). 
need for comparative analyses of the IP systems like the one offered in this paper. $^{320}$

Yet, to the extent these reward or prize proposals are taken to be replacements for the IP system there would be some objections to overcome that are worth considering here. First, the benefits such proposals offer for determining the amount and type of reward may be illusory. The systems are quite complex and so their transaction costs - both on the market side and the government side - should be carefully explored. On the market side these might influence the types of private ordering that would be able to occur around the rewards. $^{321}$ On the government side, it would be important to elucidate the ways in which at bottom these approaches do not boil down to the very Pigouvian subsidies that were the target of criticism in the path-breaking treatment by Coase of the eternality problem. That is, the rewards in these proposals are being offered to mitigate the problem raised by the positive externalities associated with the subject matter protected by IP (also seen as a public goods problem or Arrow Information Paradox problem). ${ }^{322}$ Yet, as Coase pointed out, property rights can compare favorably to Pigouvian taxes and subsidies as tools for mitigating the problem of externalities. ${ }^{323}$ As explored more fully below in the discussion of commercialization, the general nature of the reasons to suspect that prizes may not compare favorably to property rights includes concerns about both commercialization and screening. ${ }^{324}$ Unlike property rights, rewards implicate a number of problems for both commercialization and screening, as discussed immediately below.

\section{Ineffective Access}

The access side of the paradigm is similarly inapt because it is not clear that access is a problem under property rights or that access is improved in the long term without property rights. The reward literature places great emphasis on the risk that the right to exclude associated with property rights in IP will lead to insufficient access to the subject matter protected by IP essentially because of the potential monopoly distortion and transaction costs associated with the IP right to

320 In addition, the best case for each of these proposals involves mechanisms of non-trivial complexity for which a careful evaluation of its implications for each of the various costs outlined supra in Part II would be an area of fruitful further study.

321 For more on the particular role property rights can have for facilitating private ordering among diffuse individuals see supra Part II.B.4. For an application to IP see infra Part III.C.

322 For more on externalities generally see supra Part II.B.1. For more on the public goods problem in particular see supra Part II.C.4(a).

323 See supra notes 101-106 and accompanying text.

324 For more on these issues see the discussion of the commercialization theory infra Part III.C. 
exclude. As explored below in the discussion of the commercialization theory and its implications for these and other social costs in the context of IP, the reward theory concerns about these costs are in a sense both overstated in that the costs are not as great a feared and understated in that property rights can be essential for mitigating them. ${ }^{325}$

Nevertheless, in response to the risk of monopoly effect and transaction costs, reward theories advocate enforcing IP rights only as forms of liability rules, as distinct from property rules, by creating various forms of compulsory licenses, and exemptions from infringement (such as fair use or experimental use) to leave what some call an "open commons" or "public domain." Such liability rule treatment is advocated as a tool for providing adequate incentives to patentees while reducing the distortionary effects of an absolute right to exclude.

Various forms of liability treatment have been offered. For example, Ayres \& Klemperer advocate a patent litigation system characterized by uncertainty and delay, which they show could serve as a form of compulsory license, or liability rule. ${ }^{326}$ Others simply advocate various exemptions to infringement, such as for what they call fair use. ${ }^{327}$ As explored further below, the approach offered in this paper, which builds on earlier work by the same author, elucidates why access may not be improved by these proposals for liability rule treatment and indeed may be made worse.

The distinction between treatment of IP as a form of property rule or liability rule that is relevant here was elucidated in the seminal work by Guido Calabresi and Douglas Melamed. ${ }^{328}$ According to this view, an entitlement enjoys the protection of a property rule if the law condones its surrender only through voluntary exchange, ${ }^{329}$ so that holder of such an entitlement is allowed to enjoin infringement and in some cases to obtain enhanced damages as a deterrent to future infringements. ${ }^{330}$ An entitlement has the lesser protection of a liability rule if it can be lost lawfully to anyone willing to pay some court-determined compensation. $^{331}$ The holder of such an entitlement is only entitled to a court's

325 See infra Part III.C.3 (discussing monopoly effects, transaction costs, and some additional particularly salient NIE lessons on social costs for IP).

326 See, Ian Ayres \& Paul Klemperer, Limiting Patentees' Market Power Without Reducing Innovation Incentives: The Perverse Benefits of Uncertainty and Non-Injunctive Remedies, 97 MicH. L. REV. 985 (1999) (arguing that sufficient incentive to invent can be provided without the monopoly power associated with a property right).

327 See, e.g., Maureen A. O’Rourke, Toward A Doctrine of Fair Use in Patent Law, 100 COLUM. L. REV. 1177 (2000) (offering fair use exception because of excessive transaction costs causing too many market failures in the transactions over IP rights as property rights).

328 See Guido Calabresi \& A. Douglas Melamed, Property Rules, Liability Rules, and Inalienability: One View of the Cathedral, 85 HARV. L. REV. 1089 (1972).

329 See id. at 1105.

330 See id.

331 See id. at 1105-6. 
assessment of actual damages caused by the specific act of infringement. ${ }^{332}$ Put differently, the bargaining over liability rules is done against the backdrop of a possible court ordered price while the bargaining over property rules is done against a backdrop of a possible court order to not infringe (or to pay some form of enhanced damages as a deterrent to future infringement).

One lesson from the work by Calabresi and Melamed is that attention must be paid to which locus of decision-making about the true value of the underlying asset is the lowest cost provider of a correct decision. ${ }^{333}$ A liability rule can be more efficient if a collective, public, or governmental determination of the true value of the asset would be cheaper than a private evaluation reached by agreement of the parties; and conversely a property rule should be used if the private evaluation would be cheaper. ${ }^{334}$ Thus, soon after the Calabresi-Melamed framework was elucidated, Richard Posner pointed out that where private ordering implicates high transaction costs the case for liability rules is stronger. ${ }^{335}$ Yet, as Mitchell Polinsky pointed out, where decisions by a court are more costly the case for property rules is stronger. ${ }^{336}$ Applying this framework to IP, Robert Merges has pointed out that use of a property rule rather than a liability rule may be best because private parties have a comparative advantage over courts in valuing IP. ${ }^{337}$

But there are at least two additional problems relating to coordination that are raised by the distinction between property rules and liability rules. The first relates to social costs directly caused by the failed coordination among potential infringers. The second relates to the failed access indirectly caused by the decreased ability for the IP owner and those with whom it could otherwise transact to coordinate with each other to bring the invention to market.

332 See id.

333 To be sure, important additional considerations not directly applicable here have also been offered. See, e.g., Richard R.W. Brooks, The Relative Burden Of Determining Property Rules And Liability Rules: Broken Elevators In The Cathedral, 97 Nw. U. L. REV. 267, 268, n. 8 (2002) (elucidating analytical framework for assessing "the relative burden (or costs, or difficulty) faced by judges when attempting to determine property rules and liability rules").

334 Calabresi \& Melamed, supra note 328 at 1106. See also James E. Krier \& Stewart J. Schwab, Property Rules and Liability Rules: The Cathedral in Another Light, 70 N.Y.U. L. REV. 440, 447-49 (1995) (pointing out symmetries in the many problems elucidated in the literature).

335 RICHARD A. POSNER, ECONOMIC ANALYSIS OF LAW 29 (1st ed. 1972) ("where transaction costs are high, the allocation of resources to their highest valued uses is facilitated by denying property right holders an injunctive remedy against invasions of their rights and instead limiting them to a remedy in damages").

336 See A. Mitchell Polinsky, Resolving Nuisance Disputes: The Simple Economics of Injunctive and Damage Remedies, 32 STAN. L. REV. 1075, 1111 (1980) (pointing out that "the argument could easily go either way").

337 See Robert P. Merges, Of Property Rules, Coase, and Intellectual Property, 94 CoLuM. L. REV. 2655, 2664 (1994) (citing Calabresi \& Melamed, supra note 328). 
Where there are large numbers of potential infringers (which is the case for IP) liability rules make bargaining between the entitlement owner and the infringers more difficult. The use of a liability rule may create a prisoner's dilemma or collective action problem among potential infringers in which each individual's dominant strategy is to infringe in order to garner more of the potential gains from exchange for itself. ${ }^{338}$ And yet the property owner will not have adequate incentive to bargain with these infringers because such bargaining will not yield effective protection from others. The point is elaborated further by Louis Kaplow and Steven Shavell:

Consider the situation of an owner and a particular potential taker who values the car less highly than does the owner (but above the level of damages). The owner would like to bargain with the taker and pay him not to take the car. However, it would be irrational for the owner to pay this taker not to take the car, for he would subsequently have to pay another potential taker not to take the car, and then another and another. Therefore, the potential taker will tend to take the car even though the owner values it more highly. The general point, in other words, is that when courts err and set damages too low, bargaining by owners will be effectively infeasible, and socially undesirable takings will occur. ${ }^{339}$

Several negative impacts follow. First, as elucidated in earlier work by the present author:

Each infringer may calculate the impact of his marginal output on price without taking into account the output from other infringers. Such uncoordinated acts of infringement may cause collective profits - those reaped by the patentee directly and through damages awards from infringers - to fall below the total costs of

338 Kieff, Commercializing Inventions, supra note 7, at 733 (citing David Haddock et al., An Ordinary Economic Rationale for Extraordinary Legal Sanctions, 78 CAL. L. REV. 1, 17 (1990)).

339 Louis Kaplow \& Steven Shavell, Property Rules Versus Liability Rules: An Economic Analysis, 109 HARV. L. REV. 713, 765-66 (1996). Kaplow and Shavell further point out:

Our conclusion from the present argument is that a property rule enjoys a strong advantage over the liability rule, assuming, as is plausible, that the probability of underestimation of owners' values would be substantial under a liability regime. We emphasize that this conclusion does not depend upon the assumption that there is systematic underestimation of owners' values under a liability rule. Even when one assumes that courts' estimates are on average correct, but are sometimes too high and sometimes too low, the liability rule will be inferior because the occasions in which damages are too low will involve the multipletaker problem we have identified. (When damages are too high, there will be few takings, so the liability rule in such instances will be similar to a property rule.)

Id. at 766 . 
creating and commercializing the invention, resulting in a destruction of wealth. ${ }^{340}$

Thus, there is an increase in social costs directly caused by the failed coordination among potential infringers.

Second, as recognized by Haddock, McChesney, and Speigel, the threat of this potential onslaught of infringements induced by a liability rule will discourage investments in the subject matter covered by the IP right ex ante. ${ }^{341}$ As a result, the use of a property rule is particularly important for the impact it has on each potential infringer in ensuring there simply is no incentive to infringe ex ante, as compared with the type of benefit or compensation it might give the holder of the IP right ex post. ${ }^{342}$ That is, a fundamental distinction between property rules and liability rules is tied to the distinction explored earlier between static and dynamic efficiency. ${ }^{343}$ Property rules facilitate ex ante private ordering. This is the heart of the commercialization theory of IP, discussed below. ${ }^{344}$

Finally, it is important to realize that perfectly strong property rule protection for IP is not possible in the context of the existing system of commercial law for several reasons. First, as Ayres and Klemperer point out, uncertainty in how the rights will be enforced in court functions the same as enforcing those rights with liability rules, ${ }^{345}$ and largely because of the reward theories themselves there is substantial uncertainty in the rules governing the rules for obtaining IP rights, ${ }^{346}$ transacting over IP rights, ${ }^{347}$ and enforcing IP rights. ${ }^{348}$ Second, "the ability for an infringer to be kept effectively judgment proof through corporate and bankruptcy laws may also operate as a form of liability rule gloss

340 Kieff supra note 7, at 733 ("As Ayres and Klemperer recognize, if there are fixed costs of entry or exit, or if infringers have higher marginal cost than the patentee, then market entry by infringers will generate extra costs for society." (citing Ayres \& Klemperer, supra note 326, at 1015).

341 Kieff, Commercializing Inventions, supra note 7, at 733 (citing Haddock et al. supra note 338 , at 16-17).

342 Id., at 734 (citing Haddock et al. supra note 338, at 13).

343 See supra Part II.C.2(a).

344 See infra Part III.C.

345 See Ayres \& Klemperer, supra note 326.

346 See, e.g., Kieff, Registering Patents, supra note 7 (criticizing impact of reward theories on rules for obtaining patents).

347 See, e.g., F. Scott Kieff \& Troy A. Paredes, The Basics Matter: At the Periphery of Intellectual Property, Stanford Law School John M. Olin Program in Law and Economics Working Paper No. 275, forthcoming _ G.W. LAW REV. _ (2004) (criticizing impact of reward theories on rules for transacting over IP and on antitrust enforcement of IP-based transactions).

348 See, e.g., Kieff, Commercializing Inventions, supra note 7 (criticizing impact of reward theories on rules for enforcing patents and elucidating the importance of property rights protected by property rules for enforcing patents). 
on the present property rule regime."349 Third, "[o]therwise infringing uses that are by or for the federal government enjoy sovereign immunity protection that effectively results in a compulsory licensing regime." 350 Put differently, at least some extent of liability rule treatment is always available for IP.

At bottom, it is not clear that the access side of the incentive access paradigm is apt. More specifically, it is not clear that access would be improved by the use of rewards or IP backed merely by liability rules instead of property rules. In addition, as explored more fully below in the discussion of the commercialization theory of IP, property rights may indeed be important in ensuring that at least in the dynamic sense there is sufficient access in the first place. $^{351}$

\section{Allocation and Screening}

A final limitation of reward theories is that they seem to view an IP right as somehow having a one-to-one correlation with a good or service that is sold in a market. ${ }^{352}$ As a result, while on the one hand seeing the transaction costs of property rights as an obstacle to the cumulative nature of intellectual endeavors, the reward theories overlook that this very cumulative nature makes it remarkably difficult to allocate merit among various contributors to an intellectual endeavor. ${ }^{353}$ Consider for example "that the typical car or computer sold in a

349 F. Scott Kieff, Patents for Environmentalists, 9 WASH. U.J.L. \& POL'Y 307, 313 (2002) (Invited symposium piece for National Association of Environmental Law Societies annual meeting entitled "Sustainable Agriculture: Food for the Future," held March 15-17, 2002, at Washington University School of Law) (citing Kieff, Commercializing Inventions, supra note 7, at 733-34, n.154). For more on the interface between IP and bankruptcy see, F. Scott Kieff \& Troy A. Paredes, Toward an Understanding of Intellectual Property, Bankruptcy, and Corporate Control, _ WASH U. LAW. Q. _ (forthcoming 2004).

$350 \overline{I d}$. (citing 28 U.S.C. $\S 1498$ (1994), under which the government provides a limited waiver of its sovereign immunity for acts of infringement by or for the federal government and instead allows suits against the government in the U.S. Court of Federal Claims for a reasonable royalty). State governments similarly enjoy immunity under the $11^{\text {th }}$ Amendment. See Florida Prepaid Postsecondary Educ. Expense Bd. v. College Sav. Bank, 527 U.S. 627 (1999) (state immunity from patent infringement suits); College Sav. Bank v. Florida Prepaid Postsecondary Educ. Expense Bd., 527 U.S. 666 (1999) (state immunity from Lanham Act trademark infringement and unfair competition suits); Chavez v. Arte Publico Press, 204 F.3d 601 (5th Cir. 2000) (state immunity from copyright infringement suits). The point here is that anyone interested in achieving liability rule treatment for an IP right can achieve that result by prevailing on a government agency to arrange for the infringement.

351 See infra Part III.C (discussing commercialization theory).

352 See, Merges, supra note 2, at 1859-60 (criticizing common view in the literature as assuming a one-to-one correlation).

353 The seemingly humble statement of the cumulative nature of intellectual works is often attributed to Sir Isaac Newton's pronouncement after discovering calculus that "If I have seen further it is by standing upon the shoulders of Giants." Letter of Sir Isaac Newton to Robert 
single market comprises a huge bundle of patent and other intellectual property rights." 354

For example, in the model offered by Shavell and van Ypersele, the reward is determined by looking to market demand, ${ }^{355}$ yet they do not suggest how to disaggregate demand for licenses to intermittent windshield wiper technology used in cars, for example, from the demand for cars. Put differently, "[e]very market having large demand would generate droves of reward claimants each asserting to have made some contribution." 356 What is more, "no market participant would have an adequate incentive to provide the government with information relating to [the validity of the reward]."357 Only in the rare cases of two individuals claiming to have invented the same exact thing does one individual have an incentive to challenge the claim of the other. ${ }^{358}$

Put simply, when IP is the focus of a reward, the reward provider must determine how to allocate the reward, and it is likely there will be excessive claimants. When IP rights instead are protected by property rules, the allocation is made among those holding the various IP rights through whatever contracts they entered into so as to obtain commercialization. What is more, in contrast to the difficulties in setting appropriate reward discussed above, ${ }^{359}$ the positive law rules for obtaining the IP rights can serve as remarkably inexpensive screening tools for determining who will even get such a right. ${ }^{360}$

Hooke, February 5, 1575/1576, as quoted in RoBERT K. MERTON, ON THE SHOULDERS OF GIANTS: A SHANDEAN POSTSCRIPT 31 (1965) (unpacking the great deal of historical baggage associated with this famous phrase, which is often attributed to Newton, and demonstrating that Newton may actually have borrowed this phrase from Bernard of Chartres of the early Twelfth Century, who himself may have appropriated the phrase from Priscian, a Sixth Century grammarian, with many other intervening players at each stage). For a colorful and wide-ranging list by Justice Story of examples of the cumulative nature of intellectual endeavors within the context of a copyright case, see, Emerson v. Davies, 8 F. Cas. 615, 619 (C.C.D.Mass.1845) ("In truth, in literature, in science and in art, there are, and can be, few, if any, things, which, in an abstract sense, are strictly new and original throughout.... What are all modern law books, but new combinations and arrangements of old materials, in which the skill and judgment of the author in the selection and exposition and accurate use of those materials constitute the basis of his reputation, as well as of his copyright?").

354 Kieff, Registering Patents, supra note 7, at 62, n.29.

355 SHAVELl \& TANGUY VAN YPERSELE, supra note 313.

356 Kieff, Commercializing Inventions, supra note 7, at 713

357 Id.

$358 I d$., n. 75 (noting that so-called "interference" proceedings among two or more claimants to the same patent typically involve less than $0.25 \%$ of all patent applications that are filed with the Patent Office).

359 See supra Part III.A.1.

360 See infra Part III.C. 


\section{B. Problems of Prospect and Rent Dissipation Theories}

Recognizing that the lure of rewards may induce excessive rent seeking behavior leading to rent dissipation, ${ }^{361}$ in his 1977 piece on the so-called prospect theory of the patent system, which builds upon work by Yoram Barzel and others, Edmund Kitch argued that the use of property rights in the form of IP rights like patents could avoid or mitigate the rent dissipating effect otherwise associated with those rewards. ${ }^{362}$ A similar view of IP called the rent dissipation theory was offered by Mark Grady and Jay Alexander in 1992. ${ }^{363}$ The thrust of the prospect or rent dissipation approach is premised on the view that that property rights can facilitate coordination among competing users of a target asset so as to avoid overuse of other assets in the race to obtain the target. ${ }^{364}$ Kitch suggests that patents operate similarly as a tool to decrease both pre-patent and post-patent rentseeking. ${ }^{365}$ But reviewed in earlier work by the present author, there are a number of important limitations on the rent dissipating views of IP. ${ }^{366}$

\section{Extent of the Rent Dissipation}

Although rent dissipation can be a problem in theory, recent work by Michael Abramowicz adroitly points out a number of factors that may mitigate rent dissipation effects in practice. ${ }^{367}$ These factors include risk aversion; opportunity costs; diversity among those racing; the time it takes to get the reward; and externalized costs or benefits those racing impose on others, such as the income to those who sell goods and services needed by those racing or the costs to those who are bothered by the activities associated with racing. ${ }^{368}$

361 For more on rent seeking and rent dissipation see supra Part II.A.2.

362 Edmund W. Kitch, The Nature and Function of the Patent System, 20 J.L. \& ECON. 265, 265-67 (1977) (citing Yoram Barzel, Optimal Timing of Innovations, 50 REV. ECON. \& STAT. 348 (1968)).

363 Mark F. Grady \& Jay I. Alexander, Patent Law and Rent Dissipation, 78 VA. L. REV. 305, 305-310, 316-322 (1992) (going further than the building upon the prospect theory by suggesting that the particular contours of the positive law rules for obtaining and enforcing patents are and should be adapted to minimize rent dissipation both pre patent and post patent).

364 Kitch supra note at 256 (citing Barzel supra note 362).

365 Id. See also Grady \& Alexander supra note 363.

366 Kieff, Registering Patents, supra note 8, at 63-66 (pointing out limitations in prospect and rent dissipation theories). For clarity, this part of the argument is presented again in this paper in slightly expanded form, rather than more condensed form by way of citation.

367 Michael Abramowicz, Copyright Redundancy, supra note 303, at 10-18 (collecting sources and showing how each of these factors may operate to mitigate rent dissipation effects).

368 Id. at 11-12. A more palpable, albeit mythological, example of these positive externalities of racing might include the joy children experience when they drink the Tang® and use the Velcro ${ }^{\circledR}$ that many think were brought to society through the NASA-sponsored space race; the corresponding negative externalities might include the cavities some children get from increased 
In addition, rent dissipation presumes there is a single prize, or at least a discrete number of prizes. ${ }^{369}$ But those attempting to solve a problem may not arrive at the same solution; they may get to different solutions and there may be even more solutions available. ${ }^{370}$ Although multiple solutions to a given problem may be wasteful when the good is not really needed, which is an interesting possibility explored at some length by Abramowicz, ${ }^{371}$ when the utility of the good is substantial, the benefits of multiple solutions may dominate. ${ }^{372}$ That is, although more may not always be better, it also may not always be worse. Consider the multiple, independently patentable and non-infringing solutions to

exposure to this sugared drink and their difficulty tying knots after growing up with shoes kept on by hook-and-loop fasteners instead of laces. See, e.g., A. Samuel Oddi, An Uneasier Case for Copyright Than for Patent Protection of Computer Programs, 72 Neb. L. Rev. 351, 378 n.95 (1993):

The creation of "spin off" inventions has often been urged as one of the benefits of government-funded research. See George J. Howick, The NASA Technology Utilization Program, in Utilizing R \& D BY-Products 69, 78-82 (Jerome W. Blood ed., 1967) (describing NASA program and examples of spin-off inventions, including inorganic paint, walking wheel chair, maintenance-free lubricated bearings, and sight-controlled switches). Some other examples of commercial products arising out of the space program include, smoke detectors, graphite, an artificial pancreas, heated ski goggles and hang gliders, but not velcro, teflon or tang.

369 Although it is often useful when modeling a problem to reduce it to a manageable form to construct the model, the single-solution element of the rent-seeking models cannot be extrapolated to provide meaningful guidance for policymakers without at least consideration of whether in the real world the set of possible solutions to a given problem (prizes) is limited, and whether we are nearing such a limit.

370 See infra note 373 and accompanying text.

371 Abramowicz, supra note 303, at 2-9. Interestingly, the fair use defense and the utility exception to copyrightable subject matter may combine to leave uses that are needed effectively beyond the enforceable reach of any valid copyright rights.

372 An increase in the number of available solutions will increase the chance of each person gaining access to any one solution. This is one reason why the patent system does not require the claimed invention to be "better" than the prior art; it need only be new and nonobvious. As thenjudge Warren Burger wrote, quoting Judge Giles Rich:

Progress is most effectively promoted by protecting those who enrich the art as well as those who improve it. Even though their inventions are not as good as what really exists, such inventors are not being rewarded for standing still or for retrogressing, but for having invented something. The system is not concerned with the individual inventor's progress but only with what is happening to technology.

Comm'r of Patents v. Deutsche Gold-und-Silber-Scheideanstalt, 397 F.2d 656, 667 (D.C. Cir. 1968) (Burger, J.) (quoting Giles S. Rich, Principles of Patentability, 28 Geo. WASH. L. REv. 393, 393, 402 (1960), reprinted in Nonobviousness - The Ultimate Condition of Patentability 2:1, 2:9 (John F. Witherspoon ed., 1980) (admonishing that we must avoid "the unsound notion that to be patentable an invention must be better than the prior art.”). 
the problem of pain and inflammation: aspirin, acetaminophen $\left(\right.$ Tylenol $^{\circledR}$ ), ibuprofen $\left(\right.$ Advil $^{\circledR}$, Motrin ${ }^{\circledR}$ ), selective COX-2 inhibitors (Vioxx ${ }^{\circledR}$ and Celebrex ${ }^{\circledR}$ ), and various steroids. ${ }^{373}$ Some patients can only take some of these drugs, and some patients can take all, but not at all times. In the real world we cannot know ex ante whether more solutions are going to be redundant, or whether they will both increase consumer choice and provide access to more consumers who could not consume the earlier solutions. ${ }^{374}$ Competition, after all, can be a good thing.

In the least, such increased competition for research and development just might not be a bad thing. The path breaking work by Robert Solow for which he was awarded the 1987 Nobel Prize in Economics, ${ }^{375}$ demonstrated that most of the economic growth in the United States in the first half of this century could be explained by investments in research and development and education rather than by increases in capital and labor. ${ }^{376}$ What is more, while the rent dissipating models themselves are premised upon decreasing returns to scale for research and development, ${ }^{377}$ the path breaking work by Paul Romer shows that such investment in research and development and education is unlike other forms of investment in that it does not experience decreasing returns to scale. ${ }^{378}$ To be sure, though, it still is the case that resources invested towards these activities would not be invested elsewhere, and this opportunity cost must also be considered. $^{379}$

373 It is not always the case that an independently patentable invention will avoid infringement of earlier patents. Patentability of the second invention turns on a very different set of questions than its possible infringement of the first patent. The patentability analysis of the second invention will turn largely on the scope of information in the art at the time that invention is sought to be patented, which includes the disclosure in the first patent. For more on the rules of patentability over the prior art, see CHISUM, ET AL. supra note 5, at 323-706 (treatise and casebook teaching and collecting sources). The possible analysis of infringement of the first patent by the second invention will turn on the claims of the first patent. For more on the rules of patent infringement, see $i d$. at 829-1041.

374 In areas where we can make good judgments ex ante about which avenues of research are most likely to be productive, it may be possible to fund the work prospectively. The government grant-making processes such as those at NIH and NSF basically operate this way by empanelling experts in the field to review grant applications.

375 See, Press Release: The Sveriges Riksbank (Bank of Sweden) Prize in Economic Sciences in Memory of Alfred Nobel for 1987, available on line at http://www.nobel.se/economics/laureates/1987/index.html.

376 See Robert M. Solow, Technical Change and the Aggregate Production Function, 39 REV. ECON. \& STAT. 312, 320 (1957).

377 See, e.g., Loury supra 49, at 408 (noting that an assumption of the model is diminishing returns to scale of research and development).

378 See Paul M. Romer, Increasing Return and Long-Run Growth, 94 J. PoL. ECON. 1002 (1986). Increasing returns to scale means that the more that is put in, the more that is gotten out and the "bang-for-buck" does not decrease as more and more buck is added.

379 In his seminal review of the patent system Fritz Machlup pointed out: 


\section{Effectiveness of the Tools for Mitigating Dissipation}

The prospect and rent dissipation theories present themselves with the very problem they attempt to solve. As Donald McFetridge and Douglas Smith pointed out soon after Kitch, the more effective the patent is in coordinating activities of those in the industry after the patent has issued, ${ }^{380}$ the greater will be the problems of racing towards the patent application before filing. ${ }^{381}$ Kitch's response was to argue that the coordination costs are likely to be low in such early stages because there are likely to be only a small number of players then. ${ }^{382}$ But this response does not fully answer the problem. As Abramowicz correctly points out, the behavioralism and transaction costs may be high in such a community because the members may have significant cognitive biases. ${ }^{383}$ The information and transaction costs to coordinating also may be high if the racers do not know about each other. ${ }^{384}$

What is more, the central limitation of the rent dissipation and prospect theories is that they do not offer a way to use the social cost lessons of prospecting to design legal rules for obtaining patents that can operate ex ante to mitigate the social costs of prospecting. Instead, Kitch argues that the prospect theory explains why the commercial success associated with a patented invention

It is easy to conceive of the possibility that such allocation [of productive resources to research and development] is too meager. But can there ever be too much? Is not more research and development always better than less? Is it possible that too much is devoted to the inventive effort of the Nation? This depends on what it is that is curtailed when inventive activity is expanded. More of one thing must mean less of another, and the question is, what it is of which there will be less.... Whenever permanent economic policies - not just war or depression measures - are discussed, sound economists must start from the principle that no activity can be promoted without encroaching on some other activity. More of one service or product must mean less of another.

Fritz Machlup, An Economic Review of the Patent System: Study No. 15, prepared for the Subcommittee on Patents, Trademarks, and Copyrights of the Senate Committee on the Judiciary, 85th Cong., 2d Sess. 45-46 (1958). See also, Lunney, supra note 307 (pointing out the importance of considering opportunity costs).

380 Kitch, supra note 315, at 276.

381 Donald G. McFetridge \& Douglas A. Smith, Patents, Prospects, and Economic Surplus: A Comment, 23 J.L. \& Econ. 197, 202-03 (1980).

382 Edmund W. Kitch, Patents, Prospects, and Economic Surplus: A Reply, 23 J.L. \& Econ. 205, 205-06 (1980).

383 Abramowicz, supra note 303, at $184 \mathrm{n} .251$ (collecting sources on cognitive biases of overconfidence and overoptimism).

384 They may not know each other because the field may be so new that the community of people working in it is not defined. Or, the potential members of the community may generally be known, but without the freedom to divulge their work to each other that is given by a patent, they may not know enough about each other to coordinate. This latter type of coordination problem is known generally as the Arrow Information Paradox. See supra note 60. 
should be an important factor in determining whether it is patentable. ${ }^{385}$ Similarly, the rent dissipation theory urges a finely tuned patent system that will grant and enforce patents only when the balance of these pre-patent and post-patent racing costs tips just the right way. ${ }^{386}$ Yet, the rent dissipation theory does not provide a framework for making such determinations ex ante, at the time a private party would decide whether to file a patent application or at the time the Patent Office would examine it. Instead, it only identifies a select few reported judicial decisions that, according to the summary accounts of Grady and Alexander, turn out to be ex post examples of results that may have avoided rent dissipation. ${ }^{387}$

The importance of being able to make determinations about patentability and patent scope around the time of the application has been emphasized recently in a number of areas of the literature. Polk Wagner, in his work on the patent infringement doctrine called the "doctrine of equivalents," elucidates the importance of information-forcing penalty default rules as inducement to potential patentees to produce socially valuable information early in the life of the patent. $^{388}$ In addition, Clarissa Long, in her work on the often overlooked signaling function of patents, shows how in certain circumstances the information-signaling function of patents may be even more valuable to the rights

385 Kitch, supra note 315, at 282-83 (discussing commercial success). Later in the same work, Kitch may be advocating that the test for patentability over the prior art should merely be novelty, without nonobviousness. See id. at 284 ("Thus substantial novelty is an economically rational test of patentability."). Such an argument would accord with the social cost saving benefits of the registration theory outlined in Kieff, Registering Patents, supra note 8, at 76-81.

386 See Grady \& Alexander, supra note 363, at 322-47 (offering a complicated method for making patentability determinations using a host of factors, many of which are determined long after a patent application is filed, such as the importance of the patent in controlling downstream rent-dissipating effects).

387 Id. at 343-47 (discussing only a few cases in summary). Furthermore, one of the few cases Grady and Alexander rely upon as illustrative of the rent dissipation theory, General Mills v. Pillsbury Co., 378 F.2d 666 (8th Cir. 1967), does not accord with any of the prevailing trends in the case law over time. An electronic search using the Westlaw ${ }^{\circledR}$ KeyCite ${ }^{\circledR}$ service did not reveal a single case after 1974 that cited Pillsbury on this issue and further revealed that, if anything, the case is miscited by a commentator as announcing a per se rule against patents in the field of culinary arts. See Malla Pollack, Note, Intellectual Property Protection for the Creative Chef, or How to Copyright a Cake: A Modest Proposal, 12 Cardozo L. Rev. 1477, 1482 n.30 (1991) ("Food items are patentable, but the culinary creativity of chefs is not the type of creativity which meets the standards for patentability.").

388 R. Polk Wagner, Reconsidering Estoppel: Patent Administration and the Failure of Festo, 151 U. PA. L. REV. 159, 161-67 (2002) (arguing for a shift in focus from the allocation of liability during infringement (ex post) towards rules that generate incentives both during and before inventors apply for patents (ex ante) so as to better understand information-forcing default penalty rules like the limitation on the doctrine of equivalents known as the "doctrine of prosecution history estoppel," which holds out the possibility of lost patent scope as an inducement to potential patentees to produce socially valuable information early in the life of the patent.). 
holder than the substantive rights conferred by patent law. ${ }^{389}$ Put simply, ex ante predictability is essential both for facilitating the private ordering of the property owner and those with whom it contracts, and for mitigating the information costs of third parties. 390

At bottom, the prospect and rent dissipation theories of IP make important contributions by elucidating the ways that property rights can facilitate coordination among competing users of an asset so as to avoid over use of other resources. It seems from the literature that patents may indeed have this net beneficial impact in the real world.

But several implications of these theories are less clear. First, it is not clear whether other factors operate sufficiently to mitigate rent dissipation. ${ }^{391}$ Second, it is not clear whether the racing effect really generates rather than dissipates rents in this setting because at least over the medium term we may be sufficiently far from the limit of knowable information that we can continue to enjoy the broader dynamic economic growth associated with new technologies as elucidated by Solow and Romer. ${ }^{392}$ Third, it is not clear whether the theoretical benefit of coordination among competing users actually is realized by the use of property rights here. ${ }^{393}$ Fourth, unlike the commercialization theory discussed below, the prospect and rent dissipation theories do not provide any concrete teaching about how best to shape the contours of an operating positive law institution associated with the IP rights it posits that would be predictable by both property owners and third parties ex ante. ${ }^{394}$

\section{Commercialization Theory, Coordination, and Social Costs}

The commercialization theory of IP views IP backed by property rights and property rules as just one more institutional option in the set of industrial organization tools for coordinating economic activity among individuals. Coordination can occur in many ways, each with its own costs and benefits: transactions among atomistic individuals in the open market without IP rights; transactions among those connected by personal or social bonds, such as family or religion; transactions among atomistic individuals in the open market with the

389 Clarissa Long, Patent Signals, 69 U. CHI. L. REV. 625, 625-28 (2002) (exploring the signaling function of patents generally, including the potential role of the patent document itself to convey information that would not be as credible when revealed in other contexts).

390 See supra Part II.C.2(a) (highlighting importance of predictability to the property owner and those with whom it contracts); supra note 253, and accompanying text (work by Henry Smith highlighting importance of information costs to third parties).

391 See supra notes 367-368, and accompanying text.

392 See supra notes 369-378, and accompanying text.

393 See supra notes 380-384, and accompanying text.

394 See supra notes 286-387, and accompanying text. 
benefit of IP rights; transactions within the hierarchy of a firm; transactions involving the direct aid of the government such as a Pigouvian subsidy, or transactions within the hierarchy of government such as at a government lab.

The commercialization theory of IP views IP rights as filling an important niche left open by the other coordination options. Property rights can fill this niche by offering a middle ground option. That is, they offer the coordination benefits of hierarchy on the one hand and the strong incentives and information benefits of the market on the other hand. They offer a tool for collective action that relies upon and indeed facilitates private ordering. And to do so effectively and efficiently, of course, they require ex ante predictability on the one hand and they must, and indeed often do, mitigate a number of social costs on the other hand. The discussion that follows elucidates the general outline of the commercialization theory with an emphasis on connecting it to the major themes in the IP literature.

\section{Overview of the Theory}

The commercialization theory and its component registration theory are explored at some length within the context of patents in two earlier works by the present author, ${ }^{395}$ and so only an overview is provided here. The commercialization theory of IP views IP rights backed by property rules as important tools for facilitating the downstream commercialization of the subject matter that is protected by IP rights, after that subject matter has been made. ${ }^{396}$ This downstream commercialization requires coordination among the many complementary users of the IP subject matter including developers, manufacturers, laborers, managers, investors, advertisers, marketers, etc. ${ }^{397}$ Providing a focal point, or beacon, ${ }^{398}$ the publicly recorded IP right helps each of these individuals to find each other, ${ }^{399}$ and then by cracking the Arrow

\footnotetext{
395 Kieff, Commercializing Inventions, supra note 8, and Kieff, Registering Patents, supra note 8 .

396 See, Kieff, Commercializing Inventions, supra note 8, at 707-712 (discussing commercialization role of patents).

397 Id. (discussing these many players and their incentives to interact). See also supra Part II.B.4 (discussing coordination).

398 For more on the role of focal points in coordination see supra notes 172-174, and accompany text.

399 See Kieff, Registering Patents, supra note 8, at 99-100 (pointing out that the publicly recorded patent documents help coordinate commercialization by giving notice of the property right over wish bargaining or avoidance can occur). Compare, Richard A. Epstein, Notice and Freedom of Contract in the Law of Servitudes, 55 S. CAL. L. REV. 1353 (1982) (proposing "that under a unified theory of servitudes, the only need for public regulation, either judicial or legislative, is to provide notice by recordation of the interests privately created"). As discussed infra Part IV, patent and trademark function more efficiently along this dimension than copyright.
} 
Information Paradox otherwise facing them, helps them negotiate with each other. $^{400}$ At the same time, therefore, IP rights facilitate the creation and maintenance of both diversity and socialization among individuals within the market by providing these diverse individuals with incentive and means for coordinating with each other. ${ }^{401}$ In addition, as elucidated by the registration component of the commercialization theory, the positive law rules for determining when a valid IP right may be obtained protect reasonable investmentbacked expectations (and thereby decrease the risk of asset specific investments and opportunism) by making sure that the right to exclude does not block activities individuals otherwise are doing, and they do so with relatively low administrative and public choice costs. ${ }^{402}$

The commercialization theory explores the comparative role of property rights in IP as a tool for facilitating the commercialization of the subject matter it protects. Under this view, IP can be seen as offering a type of middle ground among several alternative institutional alternatives: atomized individuals in the free market without IP rights, families or other close-knit groups, the firm, and the government. As a middle ground between the open market and the firm, property rights for IP can offer the coordination benefits of the firm and the benefits of strong incentives of the market. ${ }^{403}$ At the same time, property rights for IP mitigate the risks of asset specificity and opportunism that are associated with full integration within a firm - for example, it can be easier for an inventor to walk away from a patent license with a firm than also to have to surrender a basic employment relationship with the firm. ${ }^{404}$ Property rights for IP also avoid the weakening of incentives that can be associated with integration within a firm and that can be especially pernicious where innovation is concerned. ${ }^{405}$ In addition,

400 See, Kieff, Commercializing Inventions, supra note 8, at 710 (discussing importance of property right for encouraging "holder of the invention and the other players in this market to come together and incur all costs necessary to facilitate commercialization of the patented invention."). See also supra Part II.C.4(a) (discussing the role of property rights in cracking the Arrow Information Paradox).

401 See supra notes127-130, 150-153, and 174-176, and accompany text (discussing the importance of coordination for facilitating both socialization and the specialization and division of labor, as well as diversity among market individuals in terms of both resources and preferences).

402 See Kieff, Registering Patents, supra note 8, at 76-98 (pointing out that the prior art rules for patents protect investments by third parties with low administrative and public choice costs).

403 See generally, supra notes 144-146, 163-171, 173-178, and 250, and accompanying text (exploring property rights in the context of the tradeoff between market and firm).

404 See supra note 251, and accompany text (noting the importance of public enforcement of property rights and contracts as an option for avoiding the need for coordination within a firm, which would lead to increased asset specificity and opportunism).

405 See supra note 149, and accompany text (discussing the problem of weakened incentives within a firm and the particular problem this poses for innovation). 
property rights for IP can avoid the public choice costs of government. ${ }^{406}$ They also allow more open participation than families or other close-knit groups. ${ }^{407}$ While achieving all of these benefits, property rights for IP also can protect third parties in two important ways: low information costs, ${ }^{408}$ and protection of investment-backed expectations and the concomitant asset specificity and opportunism. $^{409}$ At bottom, given the availability of certain enforcement through civil litigation backed up by government courts, ${ }^{410}$ IP rights can facilitate private ordering through coordination without the need for any additional formal hierarchy of a firm or government agency. In the end, therefore, the commercialization theory as elucidated here connects the theory of IP rights to the set of problems explored through NIE. ${ }^{411}$

What is perhaps most striking about the commercialization theory given the extent to which it is simply not discussed in most of the modern IP literature, is that as a matter of historical fact, it was the central motivation behind the framing of at least the present patent system, the 1952 Patent Act, if not also the present trademark system, the 1946 Lanham Act. ${ }^{412}$ While the commercialization theory is discussed to some extent in the contemporary IP literature, as elaborated below, a number of issues meriting response have been raised. First, the theory is often misperceived on its own terms. Second, the theory addresses many of the problems generally identified with IP rights.

\section{Common Misperceptions on the Theory}

The focus of the commercialization theory is on the incentives for diffuse individuals to decide individually to act in a way that ends up being

406 See supra note 267(exploring property rights in the context of the tradeoff between market and government).

407 See supra notes 160-161, and accompanying text (discussing the limitations of "crony capitalism").

408 See supra note 253 (discussing work by Henry Smith on the importance for property rights regimes to consider third party information costs).

409 See Kieff, Registering Patents, supra note 8 (discussing the importance of the positive law rules for validity of the IP right (in that case patents) for protecting third-party investmentbacked expectations).

410 The importance of certainty for facilitating private ordering is explored supra notes 198208, and accompanying text.

411 For a review of this set of problems see supra Part II.

$412 I d$., at 736-747 (reviewing the central role of the commercialization theory in the history of the framing of the 1952 Patent Act, which provided what essentially remains as our present patent system, by the same group that had only soon before framed the Lanham Act, which essentially remains as our present trademark system ). 
coordinated. ${ }^{413}$ While rewards may provide an incentive to act to the individual reward recipient, rewards do little compared to property rights to bring that individual together with all other complementary users to successfully engage in the complex commercialization process. ${ }^{414}$ Regrettably, this simple mechanism of the commercialization theory's coordination function is often misunderstood in the literature in several respects.

First, the link between the commercialization theory and the prospect or rent dissipation theories is often overstated. ${ }^{415}$ Put simply, the commercialization theory focuses on the ability for IP to coordinate efforts among complementary users of the asset to increase (or avoid insufficient) use of resources, whereas prospect theory focuses on the ability for IP to coordinate efforts among competing users of an asset to decrease (or avoid excessive) use of resources. ${ }^{416}$ Therefore, efforts to respond to the prospect and rent dissipation theories' concerns about overuse (rent dissipation) are inapposite to commercialization theory.

Second, the link between the commercialization theory for IP and the theory of property rights, generally, is often overlooked. That is, much of the literature overlooks the coordination function in its entirety and simply lumps the property rights aspects of the prospect theory by Kitch with the property rights aspects of the work by Demsetz on internalizing externalities. ${ }^{417}$ As elucidated in

413 Kieff, Commercializing Inventions, supra note 8, at 707-712 (discussing role of patents in coordinating complementary users of an invention so as to facilitate inventions commercialization).

414 Id. Compare the focus on providing direct incentives to the holder of the IP rights under the reward theories. See, e.g., Lemley, supra note 2, at 130 (discussing role of IP as an "incentive the right gives the owner"). For more on reward theories, which focus on such direct incentives, see supra Part III.A.

415 See, e.g., Lemley supra note 2, at 141, n. 42 (referring to commercialization theory as "elaboration" of "prospect" theory). In addition, unlike the prospect and reward theories, the commercialization theory, and its companion registration theory, has explanatory power for the positive law rules of the of the IP legal institutions.

416 See supra note 397, and accompanying text (elucidating the basic coordination function of the commercialization theory). See also Kieff, Registering Patents supra note 8, at 62-66 (discussing prospect and rent dissipation theories in relation to commercialization theory). For game theory examples of the formal link between the role property rights can have in these two different settings - described in that paper as racing games and mating games - see Dale $\mathrm{T}$. Mortensen, Property Rights and Efficiency in Mating, Racing, and Related Games, 72 AM. ECON. REV. 968 (1982).

417 See, e.g., Julie E. Cohen, Lochner in Cyberspace: The New Economic Orthodoxy of "Rights Management," 97 MiCH. L. REV. 462, 497 n.121 (1998) (citing work by Demsetz and noting: "Similar reasoning underlies Edmund Kitch's proposed 'prospect' approach to patents."); Rebecca S. Eisenberg, Patents and the Progress of Science: Exclusive Rights and Experimental Use, 56 U. CHI. L. REV. 1017, 1040 (1989) (citing work by Kitch and Demsetz and noting: "The prospect theory offers a justification for patents that is in keeping with broader theories of property 
earlier discussions, the prospect theory does focus on the role of property rights in mitigating rent dissipation. ${ }^{418}$ And Demsetz did also initially focus on property rights as a tool for internalizing externalities. ${ }^{419}$ But as Demsetz, himself, later realized:

In retrospect, it now seems to me that the theory of property rights implicit in this explanation places too much weight on externalities (where, in the case discussed, the externality is the neglected impact of hunting today on the cost of hunting tomorrow). The "Toward" that begins the essay's title, therefore, should be taken seriously. Externality here refers to an effect on the production transformation opportunities facing others, such effect being a result of actions taken by someone who does not bear the value consequences of this effect. Hunting today causes a change in the production opportunities facing hunters tomorrow. As circumstances make the externality more costly to bear, private rights adjust to reduce the seriousness of the externality. This is an important pattern of property right development. Nonetheless, private-ownership arrangements would exist even if there were no externality problems of the type being discussed.

Simply put, and as discussed earlier in Part II.B.4, property rights can be seen not merely as tools for internalizing externalities (they may have this effect and it may be needed), but more importantly as tools for facilitating coordination among the complementary users of an asset that is protected by a property right.

To be sure, property rights are not the only tool for facilitating coordination. For example, coordination can take place with the help of more organic, previously existing institutional frameworks, such as family ties, or what Haber describes as "crony capitalism." 420 Coordination can take place with the help of more engineered institutional frameworks, such as the firm, as Coase and Williamson highlight in their important work on the theory of the firm. ${ }^{421}$ But the point about property is that it provides yet an alternative method for achieving coordination. ${ }^{422}$ Each method of course has costs and benefits, and the commercialization theory of IP is focused on offering property rights in IP as just one additional option to the facilitate private ordering associated with downstream

rights elaborated by Harold Demsetz ...."); Neil Weinstock Netanel, Copyright and a Democratic Civil Society, 106 YALE L.J. 283, 309 n.108 (1996) (citing work by Kitch and Demsetz and noting: "For neoclassicists, therefore, intellectual property is less about creating an artificial scarcity in intellectual creations than about managing the real scarcity in the other resources that may be employed in using, developing, and marketing intellectual creations."); Rai, supra note 186, at 121 n.236 (citing work by Kitch and Demsetz).

418 See supra Part III.B

419 See supra Part II.B.1.

420 See supra notes 160-162, and accompanying text.

421 See supra notes 163-171, and accompanying text.

422 See supra notes 173-178, and accompanying text. 
commercialization of the subject matter that is protected by IP, after that subject matter has been made. ${ }^{423}$

Third, the commercialization theory also has been confused erroneously with the work of Schumpeter in being focused on the IP holder's assertion of control. $^{424}$ While the commercialization theory is focused on who will have an incentive and ability to negotiate with whom, it is agnostic on the question of who will end up controlling those negotiations. In fact, control will be a function of a great many factors other than who owns the IP. For example, the parties' relative wealth effects, bargaining positions, negotiating skills, other resources, holdout prices, alternative options, etc., will each impact the bottom line issue of control. In a world in which each market player may bring its own skill sets, IP sets, and other assets and opportunities to bear on development of a particular IP subject matter, the end result of who will control subsequent development and use of that subject matter is unclear, and indeed is left to the market and private bargains. At bottom, the commercialization view of IP focuses on the importance of IP backed by a property right as a tool for facilitating such a division of labor and other forms of specialization. ${ }^{425}$

Fourth, the importance the commercialization theory places on the distinction between ex ante and ex post may be confused by the different use of those terms recently by Mark Lemley. ${ }^{426}$ Under the commercialization theory, for IP to serve the commercialization function, the rules about how IP can be obtained and enforced must be knowable to all market actors ex ante, in advance of their decisions about whether to act. This means that regulation and liability rule treatment may be suspect to the extent they have the effect of re-writing agreements or changing rules ex post. ${ }^{427}$ When used in this context, the terms "ex ante" and "ex post" are used in their general sense, ${ }^{428}$ which is different than how they are used in the recent work by Mark Lemley. ${ }^{429}$ Lemley uses the term "ex

423 Kieff, Commercializing Inventions, supra note 8, at 707-710.

424 See, e.g., Lemley supra note 2, at 139, n. 35 (discussing role of patentee as coordinator due to the control exerted through the patent and citing Kieff supra note 8 and JOSEPH A. SChumPeter, CAPITAlism, Socialism, AND DEMOCRACY, 100-02 (discussing coordination through the control of a monopolist)). See also Lemley at 140 (suggesting that when the government assigns the IP right it is effectively selecting who will have "control over an area of research and development rather than trusting the market to pick the best researcher").

425 See supra notes127-130, 150-153, and 174-176, and accompany text (discussing role of property rights in facilitating specialization and division of labor).

426 See Lemley, supra note 2.

427 For a discussion of a number of such ex post changes and the problems they present see F. Scott Kieff \& Troy A. Paredes, The Basics Matter: At the Periphery of Intellectual Property, Stanford Law School John M. Olin Program in Law and Economics Working Paper No. 275, forthcoming _ G.W. LAW REV.__ (2004).

428 See supra Part II.C.2(a) (discussing differences between ex ante and ex post).

429 See Lemley, supra note 2. 
ante" in a special narrow sense to refer to the time period before any specific creative work is made. ${ }^{430}$ Similarly, he uses the term "ex post" in a special narrow sense to refer to a time period after any specific creative work is made. ${ }^{431}$ The commercialization theory relies on the term "ex ante" in the more general sense to refer to a time period before any given act occurs, with a focus on the importance of predictability. Similarly, it relies on the term "ex post" in the more general sense to refer to a time period after any given act occurs, again with a focus on predictability. That is, as these terms are used for purposes of the commercialization theory, the focus is on the ability for private actors to predict a legal result before deciding whether, or how, to act on any specific issue. Under the commercialization view of IP, predictability ex ante is essential in facilitating private ordering.

Fifth, some have suggested that "if patent law's concern is to ensure commercialization of inventions, then it is both overinclusive and underinclusive." ${ }^{, 432}$ The point is well taken, as far as it goes; but it may not account for the full reach of the commercialization theory. On the question of overinclusiveness, Abramowicz points out that "sometimes first-mover advantages will outweigh second-mover advantages."433 This is correct. But only where a sufficient number of the complementary users of the asset believes ex ante that this is the case with sufficient conviction to take on the coordinating role will coordination so easily take place without the property right. This can and likely does happen. But the point of the commercialization theory is that IP rights can make it easier for this to happen in many more settings. On the question of underinclusiveness, Abramowicz points out the need for commercialization of subject matter that does not meet the positive law rules for IP protection. ${ }^{434}$ But point of the registration component of the commercialization theory of IP is that the positive law rules for obtaining IP are normatively important for protecting the reasonable investment backed expectations of potential commercialization efforts by third parties. ${ }^{435}$ Put simply, these positive law rules about IP validity are

430 Id. at 130.

431 Id.

432 Abramowicz, supra note 317, at 174. See also Kieff, Registering Patents, supra note 8, at 68, n. 57 (noting that "participants in the Spring 2001Workshop Series of the John M. Olin Program in Law and Economics at the University of Chicago Law School [raised] a similar objection").

433 Id.

434 Id. at 174-75 ("Patent law is underinclusive because commercializers of unpatentable inventions also face the prospect of copying").

435 See Kieff, Registering Patents, supra note 8, at 68-70, and 76-98 (responding to Abramowicz by noting that the registration theory component of the commercialization theory elucidates the importance of the positive law rules for obtaining IP rights for protecting third party investments in a way that mitigates administrative costs and public choice costs). 
essential for making the IP system work well. The extent to which they leave behind some subject matter is a reason to explore the use of other tools to help coordination in those areas, such as perhaps the firm, or the government. IP does not solve all problems and it is only offered as an additional tool for helping to solve some.

At bottom, the commercialization theory sees the IP right backed by the credible threat of an injunction as playing an essential coordinating role for all the players in the commercialization process. ${ }^{436}$ Those wishing to buy title to or permission under the IP right must negotiate with the IP holder. As long as the existence of the IP right and the identity of the IP holder are readily discernible, ${ }^{437}$ each of the putative participants in the commercialization process will have an individual incentive to seek out and negotiate with that person, and through that person with each other. ${ }^{438}$

\section{Some Particularly Salient NIE Lessons on Social Costs for IP}

While the above discussions of the major law and economic theories of IP - reward, prospect, and commercialization - have gone far in elucidating the implications of many of the NIE problems explored supra in Part II, a few themes that are particularly salient to the debates over property rights in IP have not yet been expressly addressed here. These include the output restricting impacts of property rights due to problems of monopoly effects, transaction costs, behavioralism, anticommons, as well as the efficacy of government and problems of public choice. While the reward literature in particular has emphasized the concerns about output restriction, the commercialization theory elucidates why they concerns may be significantly less severe than perceived and indeed why in some cases property rights may be essential for mitigating them. The commercialization theory also elucidates why the concerns about government and public choice must not be overlooked.

436 By focusing on the right to exclude, the commercialization theory of IP differs in important ways from the general theory of property in land and goods, which typically consider more than the right to exclude. Adam Mossoff provides an excellent historical account of property theories that emphasizes the failure of approaches that focus only on the right to exclude. See Adam Mossoff, What Is Property? Putting the Pieces Back Together, 45 ARIz. L. REV. 371, 376 (2003) ("The concept of property is explained best as an integrated unity of the exclusive rights to acquisition, use and disposal; in other words, property is explained best by the integrated theory of property."). But see, e.g., Thomas W. Merrill, Property and the Right to Exclude, 77 NEB. L. REV. 730, 747-48 (1998) (suggesting right to exclude is central feature of property).

437 See Kieff, Registering Patents, supra note 8 (discussing notice function of IP).

438 See supra note 153, and accompanying text (discussing transitive nature of these interactions). See also, supra notes 172-174, and accompany text (discussing the focal point role in coordination). 


\section{(a) Monopoly Effects}

As discussed above in the context of reward theories, much of the literature on IP rights is consumed with concerns about limiting the potential monopoly power associated with property rights in IP. ${ }^{439}$ But actual empirical data is inconclusive on whether, for example, patents have been used to facilitate cartel behavior. ${ }^{440}$ Although a dominant concern of the reward literature on IP is that IP rights can confer power over price of the type generally associated with monopolies, the connection this literature draws between IP and monopolies in essence may be backwards. That is, as discussed below, IP rights often just do not confer monopoly power; and yet they can be essential anti-monopoly weapons - their availability can serve as an effective anti-monopoly vaccine for a market.

IP rights often do not confer monopoly power in large part because there is rarely a one-to-one correlation between any particular IP asset and a market. ${ }^{441}$ In addition, IP rights face competition from alternative technologies, extant and potential. $^{442}$ At bottom, for example, even a patent on the better mousetrap faces competition from existing spring and glue traps, the threat of future traps, and, of course, cats. ${ }^{443}$

What is more, IP rights can facilitate market entry, at least so long as they are backed by property rules. As a result, they can be powerful anti-monopoly weapons. ${ }^{444}$ Indeed, the commercialization theory suggests that if meaningful IP

439 See supra Part III.A.

440 See, C.D. Hall, Patents, Licensing, and Antitrust, 8 RES. L. \& ECON. 59 (1986).

441 See Kieff, Commercializing Inventions, supra note 8 at 729-731 (reviewing reasons why IP rights confer insufficient market power to be monopolies and collecting sources). See also supra note 212 (discussing relationship between IP assets and markets).

442 Id.

443 See CHISUM, ET AL. supra note 5, at 61, providing the following overview: Because the term monopoly is applied to an entire market, we begin our analysis of monopolies by looking at markets. Markets tend to order themselves around consumer demand-producers sell what consumers will buy. In general, consumers buy to satisfy their needs or desires. In the context of a particular consumer problem, like mouse infestation, for example, consumers need or want solutions; and producers sell these solutions, perhaps in the form of mouse traps or cats. We already know that a patent excludes others from making, using, selling, or offering for sale a particular invention. We now see that in the context of a market for solutions, a patentee can prevent others from selling a certain solution, though not all solutions to a given problem. Indeed, it is often said that necessity is the mother of invention, and the necessity caused by an inability to gain access to a particular patented solution-perhaps because the price is too high or perhaps because of an injunction-may very well give rise to the development of alternative non-infringing solutions.

Id.

444 Id. at 744 (discussing role of IP rights as anti-monopoly weapons). 
rights had been available in the computer software industry in the 1970's and 80 's, ${ }^{445}$ by the time of the Microsoft antitrust suit the industry likely would have been characterized by a medium number of medium-sized players rather than a single large player. ${ }^{446}$ "According to Judge Frank, in this context the David Co. v. Goliath, Inc., competition is dependant upon investment in David Co., which will not occur unless it is armed with the patent slingshot."447 At bottom, the gains IP rights may offer for competition and market entry across markets at any one time as well as across time may well offset the potential for individual dead weight loss in cases where an IP right truly conveys a monopoly in some point in time for some market. In part, this point here is tied to the distinction between dynamic and static efficiency, which is to say that the static inefficiency associated with monopoly dead weight loss may be outweighed by the dynamic efficiency gains associated with innovation and entry. ${ }^{448}$

In addition, IP rights can and often do operate to facilitate price discrimination, which can mitigate the dead weight loss efficiency considerations of monopolies. ${ }^{449}$ As explored in earlier work by the present author, the use of property rights in IP

is also consistent with another basic work by Demsetz in which he demonstrated that (1) private producers can produce public goods efficiently given the ability to exclude nonpurchasers and (2) price discrimination is consistent with competitive equilibrium for such public goods. ${ }^{450}$

Indeed, because of the doctrines of indirect infringement, IP rights facilitate price discrimination through tying in a great many more cases than otherwise, including for example where tying is not facilitated by technological constraints. ${ }^{451}$

At bottom, while IP rights do give some power over price and therefore are associated with some dead-weight loss in theory, the actual monopoly effects

445 Patents were not available because of judge-made exceptions to patent law that had crept into the law in the late 1960's. The utilitarian nature of the industry made it an unlikely candidate for benefiting in the anti-monopoly sense from copyright and trademark protection.

446 Id. (giving example of computer software industry as one in which the putative monopoly power of Microsoft was correlated with a time of no meaningful IP protection in that industry).

447 Id. (citing Picard v. United Aircraft Corp., 128 F.2d 632, 643-44 (2d Cir.

1942) (Frank, J. concurring)).

448 See supra note 209, and accompany text (pointing out the importance of exercising restraint for certain forms of antitrust enforcement designed to protect static efficiency so as to facilitate innovation and promote dynamic efficiency).

449 See supra note 214 , and accompanying text (discussing role of price discrimination in mitigating output-restricting effects of monopolies).

450 Kieff, Commercializing Inventions, supra note 8, at 727 (citing Harold Demsetz, The Private Production of Public Goods, 13 J.L. \& ECON. 293 (1970)). See also supra notes 213-214, and accompany text (discussing price discrimination as limit on monopoly power).

451 Id., at 727-730 (exploring use of IP rights as tools for facilitating price discrimination). 
of IP are overstated and the anti-monopoly benefits of IP are overlooked. Indeed, the lessons of the literature on "second-best" and the basic comparative institutional analysis of $\mathrm{NIE}^{452}$ are that there are many reasons why it may be prudent to avoid letting anti-monopoly concerns drive us to respond too aggressively to every occasion of power over price. In this sense, for example, the reward literature's concern over mitigating monopoly effect of IP can be seen as unduly exalting static efficiency over dynamic efficiency. ${ }^{453}$ Put simply, in the real world the benefits of this type of market power for capital formation and dynamic competition may outweigh its theoretical cost in the form of static deadweight loss.

\section{(b) Transaction Costs, Behavioralism, and Anticommons}

While the commercialization theory sees the nature of IP as a right backed by the credible threat of an injunction to be the core benefit of IP in providing coordination, it recognizes that this coordination requires transactions. As explored in Part II.B.2, such transactions have both good and bad components to them. They can be seen as costs. ${ }^{454}$ They also can be seen as benefits. ${ }^{455}$ But one lesson of NIE is to engage in comparative institutional analyses and so in the context of IP the comparison is between the various institutional options for achieving coordination that were surveyed earlier - e.g., open market without IP (commons), IP, family, firm, government. ${ }^{456}$ The focus of the commercialization theory highlights the coordination benefits of IP.

Yet, one of the central focuses of the reward theories is on the transaction costs associated with IP compared to a commons. ${ }^{457}$ Thus, it is appropriate to compare the transaction costs of exchanges over property rights in IP against the transaction costs of exchanges over what would otherwise be the subject matter of IP but within a realistic commons, such as the putative commons of basic academic knowledge. ${ }^{458}$ Yet, as explored in other work by the present author,

\footnotetext{
452 See supra notes 20-28, and accompanying text (discussing comparative institutional analysis)

453 See supra Part II.C.2(a) (highlighting difference between static and dynamic efficiency).

454 See supra notes 120-126, and accompanying text (reviewing transaction costs).

455 See supra notes 127-131, and accompanying text (reviewing transaction benefits).

456 See supra notes 403-407, and accompanying text (positioning IP among various institutional choices for achieving coordination).

457 See supra Part III.A (discussing reward theories and their incentive-access paradigm).

458 See, e.g. Rai, supra note 186 (arguing that IP rights impose greater transaction costs than the basic scientific norms in the open "commons" of academics); Rebecca S. Eisenberg, Proprietary Rights and the Norms of Science in Biotechnology Research, 97 YALE. L.J. 177 (1987) (exploring the potential negative impact of patent rights on scientific norms in the field of basic biological research); see also, e.g., Rebecca S. Eisenberg, Patents and the Progress of Science: Exclusive Rights and Experimental Use, 56 U. CHI. L. REV. 1017 (1989) (exploring an
} 
even this so-called "commons" is riddled with its own form of less commercial but nonetheless important property rights known informally as "kudos," which include more personal and less fungible assets generally associated with academic and public sectors such as reputational benefits, fame, promotions, awards, titles, etc. $^{459}$ Earlier work by the present author has elucidated through comparative institutional analysis why for exchanges in that setting of a putative commons compared with the same setting having added IP rights, the transaction costs of exchanges are likely to be worse without IP than with IP because IP brings increased wealth and diversity to that market. ${ }^{460}$ One of the lessons of NIE explored earlier is that transaction costs are likely to be more pernicious in thinner markets than in thicker markets, ${ }^{461}$ That is, transaction costs are likely to be worse in thinner markets than in thicker markets and the use of IP thickens the market. ${ }^{462}$ As also discussed earlier, recent work by Buchanan and Yoon adds to this analysis by pointing out that exchanges in such a commons also are more likely to fail because of what they call the "non-economic motivations" associated with such assets. ${ }^{463}$ Put simply, there are reasons to think that transaction costs are likely to be higher for a commons compared to for IP.

Somewhat related to the concerns over transaction costs in the reward literature are similar concerns about behavioralism. More specifically, in response to concerns about behavioralism leading to failures in transactions over IP rights, commentators have called for regulation for IP rights through the imposition of liability rule treatment and greater antitrust enforcement. ${ }^{464}$ To be sure, like all actors in the real world, IP owners are not perfectly rational. That is, people are only boundedly rational in that they suffer cognitive biases, framing

experimental use exemption from patent infringement as a device for alleviating potential negative impact of patent rights on scientific norms in the field of basic biological research); Rebecca $\mathrm{S}$. Eisenberg, Public Research and Private Development: Patents and Technology Transfer in Government-Sponsored Research, 82 VA. L. REV. 1663 (1996) (offering preliminary observations about the empirical record of the use of patents in the field of basic biological research and recommending a retreat from present government policies of promoting patents in that field); Heller \& Eisenberg, Anticommons, supra note 277 (arguing that patents can deter innovation in the field of basic biological research).

459 Kieff, supra note 185.

460 Id.

461 See supra notes 133-134, and accompanying text.

462 Kieff, supra note 185, at 703-4.

463 See supra note 281, and accompanying text.

464 See, e.g., Lemley supra note 2, at 133 (citing Mark A. Lemley, The Economics of Improvement in Intellectual Property Law, 75 TEX. L. REV. 989, 1048-72 (1997) (discussing implications of relaxing rationality assumption for IP); Wendy J. Gordon, Asymmetric Market Failure and Prisoner's Dilemma in Intellectual Property, 17 U. DAYTON L. REV. 853, 857 (1992) (pointing out costs of rationality assumption). 
effects, employ heuristics, etc. ${ }^{465}$ On the one hand, identification of behavioralism concerns does suggest reasons to be skeptical about the ability for individuals to actually achieve for themselves what is in their own best interest, and behavioralism has justified resort to liability rules, regulation, immutable contract terms, etc. On the other hand, the individuals the government will use to affect these responses - legislators, regulators, and judges - are, of course, human beings, too, and so will also suffer the limits of behavioralism. ${ }^{466}$ What is more, these government decisions will be subject to public choice problems, discussed below. ${ }^{467}$

At bottom for IP, the behavioralism limits of the market are important costs to consider about the market. To the extent the alternative to IP is simply lack of IP, then the countervailing considerations are the coordination benefits the commercialization theory highlights. ${ }^{468}$ But to the extent regulation of the IP is the alternative, then behavioralism limits for the government actors associated with the regulation are also important countervailing considerations to consider. What is more, to the extent the regulation will occur ex post, then interference with ex ante incentives is an additional countervailing consideration to letting behavioralism concerns justify deviation from basic property treatment for IP. ${ }^{469}$ Finally, regulation brings with it the inevitable costs of government, including the tollbooth and rent-dissipation problems of agency capture, as well as the real concomitant problems of permit thickets, License Raj, or anticommons. ${ }^{470}$

Ironically, much of the recent literature advocating enhanced regulation of IP rights is tied to misplaced reliance on anticommons concerns. ${ }^{471}$ These concerns are misplaced for several reasons.

In contrast to the real anticommons problem of the post socialist economy discussed earlier, ${ }^{472}$ the dominant private value that an IP owner obtains from the IP right to exclude use is by openly trading permission for use in exchange for

465 See supra Part II.A.4 (reviewing behavioralism problems as explored through NIE literature).

466 See Paredes, supra note 70 (pointing out countervailing behavioralism problems for government actors, as well as public choice problems, and collecting sources).

467 Id. See also, infra Part III.C.3(c) (discussing public choice).

468 See supra notes 396-412, and accompany text (overview of coordination benefits of commercialization theory).

469 See supra Part II.C.2(a) (discussing importance of ex ante analysis).

470 See supra Part II.C.3 (discussing public choice problems of rent dissipation and tollbooths). See also supra Part II.C.4(b) (discussing the problems of permit thickets, License Raj, and anticommons).

471 See, e.g., Heller \& Eisenberg, Anticommons, supra note 458 (initiating literature on anticommons for IP); Kieff, supra note 14, at (reviewing Supreme Court cases expressing anticommons concerns about IP).

472 See supra Part II.C.4(b) (discussing anticommons problem). 
money or other consideration. ${ }^{473}$ As discussed earlier the economic motivations associated with such "residual claims" are precisely what mitigate anticommons concerns. ${ }^{474}$ Indeed, even the potential for a drive to suppress the subject matter protected by IP is mitigated by the uncertainty that higher untapped value may lie in wait. ${ }^{475}$ Put simply, the resulting social value of IP rights is that they encourage their owners to discover and market methods for pushing use towards the full competitive level so the IP rights will not create anticommons problems, in biotechnology, software technology, or even for more mundane technologies like nails and screws. ${ }^{476}$

What is more, the reward literature on IP gets the concerns about anticommons backwards. Not only are anticommons problems for IP overstated, the response generated by these concerns of liability rule treatment and regulation are likely to generate true anticommons problems. There is a huge difference between the openly tradable nature of property on the one hand and the pernicious "permit thicket" or "License Raj" on the other hand. At bottom, residual claim, tradability, enforceability, and private information are each reasons that IP rights are successful in avoiding anticommons effects.

Interestingly, the realization that IP rights do not trigger anticommons concerns does suggest that it is worth pushing on the analogy to real and personal property rights and ask whether it makes sense for IP to be time-limited. ${ }^{477}$ Patents, copyrights, and trademarks are each time-limited to some extent, ${ }^{478}$ but property rights in real and personal property do not simply expire. Recent work by William Landes and Richard Posner has suggested a regime in which IP rights

473 That is, the IP owner may either actively license the IP to someone else who will in turn sell the subject matter protected by the IP, or the IP owner itself may sell the subject matter protected by the IP, which sale would include an implied license to the IP for its buyers. See F. Scott Kieff, Perusing Property Rights in DNA, in F. ScotT KiefF, Perspectives ON Properties OF THE HuMAN GENOME PROJECT 125 (2003); Kieff, supra note 185.

474 See supra notes 279-285, and accompanying text.

475 See Kieff supra note 8 at 726 (commercialization risk and potential for future development provides incentives to license broadly).

476 See Kieff, Perusing Property Rights in DNA, supra note 473.

477 I thank Bruce Owen at the Stanford Institute for Economic Policy Research for suggesting this exploration. Conversation with Bruce Owen February 25, 2004. Lemley seems to suggest this notion offhandedly but does not explore it, and indeed seems critical of it. See Lemley supra note 2, at 131 (suggesting commercialization view may support "perhaps unlimited duration" for IP rights).

478 By statute, patents expire after 17 years, on average (20 years from filing, and examination takes three years, on average). For a brief discussion of the change from a 17 to 20 year patent term, see CHISUM, ET AL. supra note 5, at 898-900. Also by statute, copyrights expire after a time certain. 17 U.S.C. $\$ 302$ (2000) (life of the author plus 70 years for works by individual authors, or the shorter of 95 years after publication or 120 years after creation for works made for hire, anonymous works, and pseudonymous works). Trademarks last only so long as the mark is used in commerce in a consistent fashion. 
might be infinitely renewable; under their proposal the default for failure by the IP owner to act is that the IP passes into the commons. ${ }^{479}$ The commercialization benefits of IP suggest that it might be worth considering why the default position is commons, rather than continuing status as property. When owners of personal and real property are negligent custodians of their assets, the default position is not that they fall into the public domain, but rather that they remain the subject of private ownership. To be sure, the original owner typically loses title, but ownership itself is not destroyed and indeed is most often essentially put up for auction. $^{480}$ Perhaps IP, too, should be left the subject of private ownership and merely put up for auction if left sufficiently fallow.

Implementing perpetual IP would not be conceptually difficult. ${ }^{481}$ IP owners could be required to maintain updated records in a central filing office so anyone thinking they can put the IP to higher and better use will be able to initiate negotiations at low cost. If the records are not kept (and perhaps a fee to cover their maintenance at a central office not paid), then the IP would be condemned and put up for auction.

Some may suggest that surrender should also occur if the IP owner fails to either practice the subject matter covered by the IP or license the IP for someone else to practice. But it is not clear that such an approach would be good. The relative restrictive power of a property right in real or personal property is greater

479 William M. Landes and Richard A. Posner, Indefinitely Renewable Copyright, 70 U. CHI. L. REV. 471 (2003).

480 Foreclosure sales, and tax sales are the most common type, but even adverse possession can be thought of as a type of auction open for bidding by the first to become adverse possessor.

481 Indeed, trademark rights already are potentially unlimited in duration, so long as they remain in consistent use. See In re DC Comics, Inc., 689 F.2d, 1042, 1046-55 (CCPA 1982) (opinions by Judges Rich and Nies concurring in result and reviewing the life-cycle of a trademark - beginning with initial use and ending only with abandonment or genericness); see also Daphne Leeds, Trademarks - The Rationale of Registrability, 26 GEO. WASH. L. REV. 653, 666 (1958). For patents and copyrights, the term may be limited by the language of the constitutional grant of power under which these regimes are presently promulgated, wherein Congress is given the power

[t]o promote the Progress of Science and useful Arts, by securing for limited

Times to Authors and Inventors the exclusive Right to their respective Writings and Discoveries.

U.S. Const., Art. I, Sec. 8, Cl. 8. In contrast the trademark laws are promulgated under the general Commerce Clause power of Article 1 that is now recognized to be quite expansive. Compare In re Trade-Mark Cases, 100 U.S. 82, 95 (1879) (holding trademark laws to be improper exercise of Commerce Clause power because they regulate activity that is not sufficiently interstate) with Wickard v. Filburn, 317 U.S. 111 (1942) (holding that even growing wheat for personal consumption in one's own back yard has sufficient nexus to interstate commerce that it may be regulated by Congress using Commerce Clause power). Thus, the patent and copyright could be similarly viewed as at least within Constitutional power if passed pursuant to the same commerce clause power. For an interesting recent treatment of this option see Thomas B. Nachbar, Intellectual Property and Constitutional Norms, 104 COLUM. L. REV. 272 (2004). 
than that in IP because the total subject matter protectable by real and personal property is limited - there is only so much stuff and real estate available in the world - while the total subject matter protectable by IP rights has a limit that is not even known. Only to the extent we think we are approaching the limit of knowable IP subject matter - inventions, creations, and symbols - is the restrictive power of IP potentially as great as that for real and personal property. Importantly, perpetual property rights in real and personal property is the norm precisely because we think that best allows for private actors to consistently evaluate and shift real and personal properties towards their highest and best use. Just as an empty plot of land is not automatically transferred into a commons for lack of use, perhaps neither should IP be left to the commons. And just as concerns about transaction costs or anticommons do not allow the user of a plot of land to elect not to treat the claims of labor and suppliers as undue and thereby avoidable when building on that plot, such concerns perhaps should not worry those wishing to use subject matter covered by IP.

Nevertheless, earlier work by the present author has identified at least one reason why extended term for IP may be problematic. ${ }^{482}$ But this has nothing to do with transaction costs and anticommons but rather with coordination and commons. ${ }^{483}$ The concern is that over time there may become fragmentation of ownership. This is less of a problem for real and personal property than it is for IP. Real and personal property may have private value to co-owners absent cooperation by other co-owners, as long as there is not too much interference by the co-owners. For example, one owner may still play baseball on a co-owned empty lot without active cooperation from the other co-owners. Because IP only includes the right to exclude, not the right to use, a co-owner may not sue to

482 I perhaps incorrectly agreed with concerns in the reward literature about transaction costs and anticommons concerns. Kieff supra note 8, at 734-735 (expanded term may exacerbate anticommons problems). But I also suggested that increasing term might trigger commons problems of the very type IP and commercialization are designed to avoid:

Indeed, the possibility of fragmented ownership presents a particular problem for [IP]. The [IP] right is only a right to exclude, not a right to use. In addition, each co-owner of a patent can decide not to exclude third parties, by giving a partial assignment or license, without accounting to any other coowner. As a result, an assignment by a co-owner will dissipate the entire value of the patent for all other owners. For this reason, it is well recognized that co-ownership in patents can create a tragedy of the commons.

Id. at 735 (citing Robert Patrick Merges, PAtent LAW And Policy 1228-36 (2d ed. 1997). 483 Id. 
enforce that right without joining in the lawsuit all other co-owners. ${ }^{484}$ Put differently, inaction by a co-owner is tantamount to a free license to the world.

In the end, the idea of perpetual ownership for IP certainly requires further consideration before adoption. The point of raising it here is because it is helpful in elucidating the implications of the commercialization theory in operation. The focus of commercialization is making sure that all of the different complementary users of the IP subject matter can coordinate with each other. It sees the role of IP as the focal point, or beacon, that brings these diverse actors together. At bottom, what provides them with incentives to indeed come together is the identification of this beacon combined with its exchange attributes: residual claim, tradability, enforceability, and private information.

\section{(c) Public Choice}

Public choice problems have, at least until recently, almost entirely escaped attention in the IP literature. Nevertheless, public choice problems do matter and should be considered because they are linked inextricably to government action, and so must be weighed as countervailing considerations to the extent regulation is offered as an alternative to IP. ${ }^{485}$ Indeed, the recent recognition of public choice problems in the body of IP literature that discusses copyright term extension only scratches the surface. ${ }^{486}$

484 See, Schering Corp. v. Roussel-UCLAF SA, 104 F.3d 341, 345 (Fed.Cir.1997) ("one coowner has the right to impede the other co-owner's ability to sue infringers by refusing to voluntarily join in such a suit.'”)

485 For more on public choice generally see supra Part II.C.3.

486 The recent IP literature often discusses the recent Copyright Term Extension Act ("CTEA") as an example of public choice pressure from the entertainment industry. While this may be so, it gravely underestimates the public choice problems in IP general, and in copyright in particular. For more on the problems in copyright see the discussion infra Part IV.A. For examples of the public choice view of the CTEA, see, e.g., Free Mickey Mouse: Lawrence Lessig Wants Less Copyright Protection, The Economist, Oct. 12, 2002; Michael H. Davis, Extending Copyright and the Constitution: "Have I Stayed Too Long?," 52 FLA. L. REV. 989, 1005 (2000) (arguing that the CTEA provided "not an incentive, but a gift or windfall"); William Patry, The Failure of the American Copyright System: Protecting the Idle Rich, 72 NOTRE DAME L. REV. 907, 932 (1997) ("[t]he real impetus for term extension" was to benefit "a very small group: children and grandchildren of famous composers whose works are beginning to fall into the public domain, thereby threatening trust funds"); Richard A. Epstein, The Dubious Constitutionality of the Copyright Term Extension Act, 36 LOY. L.A. L. REV. 123, 128 (2002) (CTEA "pads the wealth of the widows and children of the original copyright holders" and is a "massive giveaway of public domain resources"); Dennis S. Karjala, Judicial Review of Copyright Term Extension Legislation, 36 LOY. L.A. L. REV. 199, 232-36 (2002) (setting forth basic public choice view of CTEA). Larry Lessig has gone so far as to refer to the statute itself as the "Mickey Mouse Protection Act" in reference to perceived public choice pressure brought by Disney. Doug Bedell, Professor Says Disney, Other Firms Typify What's Wrong with Copyrights, DaLlas MoRNING NEWS, Mar. 14, 2002, at 3D. 
For IP, the problems of public choice are quite real. For example, when decisional frameworks in IP have been left open to sui generis determination, as opposed to being guided by applicable statutory framework, courts and agencies have acted swiftly to eviscerate IP. ${ }^{487}$ Even if any of market power, transaction costs, anticommons, or behavioralism is a concern that ought to drive regulation of IP, the central problem that public choice adds to the mix, and one which is often overlooked by the literature, is that too often these concerns have been invoked in particular cases to restructure particular arrangements ex post for the benefit of one particular constituency or set of constituencies. ${ }^{488}$ Only if the government actions called for in the literature were to totally eliminate IP or to regulate it through revisions to statutory or regulatory decisional frameworks that were sufficiently predictable, would these types of public choice problems be potentially mitigated, including their negative impact on ex ante incentives and private ordering.

487 Examples in the patent context include the agency and court decisions to prohibit patents in software and modern biotechnology, which were finally reversed by later court decisions. See, Diamond v. Diehr, 450 U.S. 175, 187 (1981) ("A claim drawn to subject matter otherwise statutory does not become nonstatutory simply because it uses a mathematical formula, computer program, or digital computer.") and Diamond v. Chakrabarty, 447 U.S. 303, 309-18 (1980) (holding living organisms not per se unpatentable).

${ }_{488}$ For at least the computer software example, the agency capture story is well known, beginning with the decision in Gottschalk v. Benson, 409 U.S. 63 (1972) (holding software to be not eligible for patent protection). As described by Judge Rich:

I find it more significant to contemplate the identities of the troops lined up for battle in Benson and observe which side obtained the victory. On the one side was the Government, against patenting programs or software, supported by the collective forces of major hardware (i.e., computer) manufacturers and their representative associations who, for economic reasons, did not want patents granted on programs for their machines. On the other side was Benson et al. and their assignee and assorted lawyers and legal groups who were in favor of patent protection for programs or software. The anti-patenting forces won the victory...

In re Johnston, 502 F.2d 765, 774 (CCPA 1974), reversed by Dann v. Johnston, 425 U.S. 219 (reversing on other grounds than those discussed in the excerpt). The majority opinion in Benson relies heavily on the 1966 report by a Presidential Commission on the patent system, which also evidenced public choice issues. As described by former Patent Office Commissioner Gerald Mossinghoff:

The 1966 report of the President's Commission on the Patent System was largely a battle between AT\&T, which strongly supported the patenting of software, and IBM, which bitterly opposed it. IBM's position as a mainframe manufacturer and seller was that software should be unpatentable and should be given away free of charge. AT\&T, as primarily a software developer, felt precisely the opposite.

Gregory J. Maier \& Robert C. Mattson, State Street Bank in the Context of the Software Patent Saga, 8 Geo. MASON. L. REV. 307, 336 n.63 (1999) (citing interview with the Honorable Gerald J. Mossinghoff, former Commissioner of Patents and Trademarks, in Arlington, Va. (Sept. 13, 1999)). 
Put differently, if in any given case a party may invoke concerns about market power, transaction costs, anticommons, or behavioralism as a justification for avoiding IP, then we should not be surprised to see many cases in which parties make precisely such charges, successfully. ${ }^{489}$ What is most troubling about the concerns expressed in the literature about market power, transaction costs, anticommons, or behavioralism, is that no attempt is made to suggest a decisional framework for determining ex ante when these concerns will be enough to trigger government action. This leaves open the possibility of a return to the time when the decisional framework by courts was so obtuse that either no IP right could satisfy them, ${ }^{490}$ or so unpredictably able to be satisfied that the effective value of all impacted IP rights simply collapsed towards zero. ${ }^{491}$

489 See Milton Friedman, Why Government is the Problem, Hoover Institution Essays on Public Policy (1993), 7-13:

The general rule is that government undertakes an activity that seems desirable at the time. Once the activity begins, whether it proves desirable or not, people in both the government and the private sector acquire a vested interest in it. If the initial reason for undertaking the activity disappears, they have a strong incentive to find another justification for its continued existence.

Again, let me emphasize, the problem is not that bureaucrats are bad people.

The problem, as Marxists would say, is with the system, not with the people.

490 For example, the test for patentability has at different times become so rigid for some courts that no patents were held valid within their jurisdiction. The standard had become so vague and yet so difficult to satisfy throughout the U.S. by the early 1940's that Justice Jackson remarked "[T]he only patent that is valid is one which this court has not been able to get its hands on.” Jurgensen v. Ostby \& Barton Co., 335 U.S. 560, 572 (1949) (Jackson, J., dissenting). Even after the statute was amended in response to these cases, the problem persisted in the Second Circuit as late as the 1960's. See Gerald J. Mossinghoff, Side Bar: The Creation of the Federal Circuit, in CHISUM ET AL. supra note 5, at 30, 30-31 (former Patent Office Commissioner Mossinghoff recounting that during the confirmation hearings for then-Second Circuit Judge Thurgood Marshall's nomination to the Supreme Court, Judge Marshall responded to a question about patents by saying "I haven't given patents much thought, Senator, because I'm from the Second Circuit and as you know we don't uphold patents in the Second Circuit").

491 This is in effect the "permit thicket," "License Raj," or true anticommons problem discussed earlier. See supra Part II.C.4(b). The problem is more colorfully described by Dickens within the context of IP:

At the Patent Office in Lincoln's Inn, they made 'a draft of the Queens bill', of my invention, and a 'docket of the bill'. I paid five pound, ten, and six, for this. They 'engrossed two copies of the bill; one for the Signet Office, and one for the Privy-Seal Office'. I paid one pound, seven, and six, for this. Stamp duty over and above, three pound. The Engrossing Clerk of the same office engrossed the Queen's bill for signature. I paid him one pound, one. Stamp-duty again, one pound, ten. I was next to take the Queen's bill to the Attorney-General again, and get it signed again. I took it, and paid five pound more. I fetched it away, and took it to the Home Secretary again. He sent it to the Queen again. She 
At bottom, public choice problems are an important countervailing consideration to the regulatory proposals suggested throughout the reward literature in response to concerns about IP, including concerns relating to power over price, transaction costs, anticommons, or behavioralism. In the comparative institutional analysis, the question to always consider is not merely whether a particular problem can be fixed, but rather, all things considered, the state of affairs in general is improved by following the particular prescription to fixing that particular problem.

\section{IMPLICATIONS FROM NIE FOR COMPARING IP REGIMES}

While the positive law IP regimes of patent, trademark, and copyright, each comprise substantial bodies of law, a thorough discussion of which is beyond the scope of this article, several core features of each essentially establish the overarching approach to their institutional framework. The point of the discussion here is that these core features have particularly significant implications for a comparative institutional analysis across these different regimes.

This comparative institutional analysis employs the central lessons from NIE that were explored earlier. ${ }^{492}$ In summary, these lessons include that property rights and IP can provide an important additional and middle-ground tool for optional use by individuals engaged in private ordering beyond those offered by the extreme poles of either the free, open market without them on the one hand, or the hierarchy of family, firm, or government on the other hand. ${ }^{493}$ To facilitate private ordering effectively, IP rights must operate as rights of exclusion around which coordination can take place. To do so efficiently, they must be structured to mitigate the costs of rent dissipation, information, transactions, and public choice.

The following comparative outline of the IP regimes suggests that the patent and trademark regimes generally function well along these metrics because they employ relatively crisp forms of property backed up by property rules, based

signed it again. I paid seven pound thirteen, and six, more, for this. I had been over a month at Thomas Joy's. I was quite wore out, patience and pocket.

Charles Dickens, A Poor Man's Tale of a Patent, in Charles Dickens and the 'Poor Man's Tale of a Patent' 15, 18-19, 29 (Jeremy Phillips ed., 1984) (including appendices about the "circumlocution office" described to be "(as everybody knows without being told) the most important Department under Government").

492 See supra Part II.

493 For elaboration on the role of property rights as a middle ground see supra notes 144$146,163-171,173-178$, and 250, and accompanying text (exploring property rights in the context of the tradeoff between market and firm). See also supra note 267(exploring property rights in the context of the tradeoff between market and government). 
on relatively easy to apply decisional frameworks in their organic statutes on both validity and enforceability. At bottom, these systems facilitate private ordering while mitigating social costs by basically operating in accordance with the commercialization theory, as discussed above. ${ }^{494}$ In contrast, the copyright regime does not facilitate private ordering, and indeed seems to operate in accordance with the dysfunctional reward theories, as also discussed above. ${ }^{495}$

Of some note in this comparative institutional analysis is that these different IP regimes evolved through remarkably different legislative histories. Through what may have been mere historical happenstance, ${ }^{496}$ the patent and trademark regimes both grew out of a concerted effort about the same time, the 1940's, by the same bar association, the New York Patent Law Association. ${ }^{497}$ Focused not on any particular set of clients, owners or infringers, but rather on crafting a coherent system, these efforts produced institutional frameworks that generally cohere and as a result are effective and efficient at achieving their core goal, which is commercialization, as discussed below. ${ }^{498}$ In contradistinction, statutes shaped through interest group politics, including the copyright statute, are plagued by a host of public choice legislative compromises. The copyright regime that resulted from this process turned out to be significantly less effective and less efficient in facilitating coordination. Thus, an important area for further research would include a careful comparison of the operative legislative histories of these different regimes to determine the reasons why they seemed to have taken such different approaches and led to such different results.

494 See supra Part III.C (reviewing commercialization theory).

495 See supra Part III.A (reviewing reward theories and their limitations).

496 Id. at 740:

Heady with success in implementing the Lanham Trademark Act [our present trademark system] a few years earlier, in 1948, the New York Patent Law Association had Giles Rich draft for introduction in Congress a bill [that eventually became the 1952 Patent Act, our present patent system].

497 The organization is presently called the New York Intellectual Property Law Association. For a historical review of the organization see, Gregory J. Battersby, et al, A Seventy-Five Year History of NYIPLA, available on-line at http://www.nyipla.org/public/01_history.html.

498 The point here is not that these statutes are perfect. The drafters of these statutes, like all human beings, are characterized by human foibles including, for example, behavioralism. Rather, the point is that because of the way they were organized during the drafting process, the individual incentives they each faced happened to be more consistent with their efforts being directed towards drafting a statute that coherently achieved the coordination function to which they had subscribed than with their efforts being directed towards helping any one class of client. At a minimum, they were largely isolated from public choice pressures. 


\section{A. The Basics of Positive Law IP Regimes}

As explored in earlier work by the present author, the positive law rules for enforcing and obtaining patents are effective and efficient in achieving coordination benefits while minimizing social costs. ${ }^{499}$ Coordination is needed for inventions because their commercialization is a costly, risky, and complex process in which second-mover advantages can dominate, and which requires many diverse actors besides inventors, including, for example, capitalists, developers, laborers, managers, and advertisers. ${ }^{500}$

The rules for enforcing patents facilitate coordination among all of these individuals by helping the patent itself serve as a coordinating focal point, or beacon around which to gather. ${ }^{501}$ This beacon effect is achieved by allowing patentees to elect to sue or license ${ }^{502}$ anyone who directly infringes, ${ }^{503}$ induces infringement, ${ }^{504}$ or contributes to infringement. ${ }^{505}$ Of course, money often can be made best by avoiding lawsuits, and instead negotiating against the backdrop of their threat. And the diverse contracting that is facilitated by these positive law rules is important for pushing output of the patented invention towards the full competitive level. ${ }^{506}$

The positive law rules for obtaining patents mitigate social costs in several respects. The disclosure rules facilitate this private ordering by giving public

499 Kieff, Commercializing Inventions, supra note 8 (exploring law and economics of positive law rules for enforcing patents); Kieff Registering Patents supra note 8 (exploring law and economics of positive law rules for obtaining patents).

500 Id. supra note 8 at 707-08 (citing U.S. CONGRESS, OFFICE OF TECHNOLOGY ASSESSMENT, Pub. No. OTA-BP-ITC-165, INNOVATION AND COMMERCIALIZATION OF EMERGING TECHNOLOGY 3, 20-96 (1995) (collecting sources and setting forth as principle findings and describing in detail how successful commercialization is not simply a matter of developing technology first or getting to market first and instead requires intellectual property protection to create an environment conducive to securing complimentary assets, skills, capital, manufacturing, marketing, and support)).

501 See supra note 398 (discussing focal point or beacon effect of patents).

502 See Kieff, Commercializing Inventions, supra note 8, at 736-38. Before the 1952 Act, courts had used the misuse doctrine to erode the ability for intellectual property owners to price discriminate or engage in restricting licensing. Section 271(d) expressly states that such conduct shall not be misuse. See also Dawson Chem. v. Rohm and Haas Co., 448 U.S. 176 (1980) (recognizing impact of Section 271(d) and its reason for inclusion in the 1952 Patent Act). To be certain this was clear, Congress acted again in 1988 by adding subparts 4 and 5 to Section 271(d) of the Patent Act to expressly provide that neither a refusal to license nor a tying arrangement in the absence of market power is patent misuse. See 35 U.S.C. $\S 271$ (d)(4-5) (added by Pub. L. No. 100-703, 201, 102 Stat. 4676 (1988)).

503 Section 271(a) (direct infringement).

504 Section 271(b) (inducement of infringement).

505 Section 271(c) (contributory infringement).

506 The diverse contracting that is allowed facilitates both price discrimination and coordination among complementary users. See, Kieff \& Paredes, supra note 427 at 9-11. 
notice of the property right. ${ }^{507}$ They also help protect third parties' reasonable investment backed expectations by helping these third parties to avoid inadvertent trespass. ${ }^{508}$ Third parties' reasonable investment backed expectations also are protected by the rules about patentability over the prior art, which protect any verifiably prior investments. ${ }^{509}$ Importantly, these patentability rules are all enforced with rules biased in such a way that they involve remarkably low administrative, public choice, and both Type I and Type II error costs. ${ }^{510}$ Indeed, because patentees are the ones who are lowest cost processors of the information needed to assess validity information costs are mitigated when property the owners themselves are given such strong incentives to make these determinations, and recent empirical models suggest these incentives do work. ${ }^{511}$ As elucidated by Anderson \& Hill, this type of owner-driven system for establishing property rights tailor-made to the needs of the owners is the best candidate for mitigating the rent-dissipation that otherwise can accompany the establishment of property rights. ${ }^{512}$

When put to the test in practice, patent law seems to work. For example, the 1980 shift in positive patent law that opened patents to the field of modern biotechnology is at least consistent with the conclusion that patents do indeed work to facilitate coordination. Only in the U.S. and only since 1980 have patents been available in modern biotechnology. ${ }^{513}$ And only in the U.S. and only since 1980 has the biotechnology industry been characterized by not only the large companies often collectively called "Big Pharma," but also by a steady pool of roughly 1,400 small and medium-sized companies that is also consistently turning over. $^{514}$

507 See Kieff Registering Patents supra note 8, at 99-105.

508 See Id.

509 See Id. at 76-99.

510 See, F. Scott Kieff, How Ordinary Judges and Juries Decide the Seemingly Complex Technological Questions of Patentability over the Prior Art, in F. SCOTT KIEFF, PERSPECTIVES ON Properties of THE Human GenOME Project 125 (2003).

511 See Amalia Yiannaka \& Murray Fulton, Privately Optimal Patent Breadth UNDER THE THREAT OF PATENT VALIDITY CHALLENGES, presented to the $8^{\text {th }}$ International Consortium on Agricultural Biotechnology Research (ICABR): International Trade and Domestic Production, held in Ravello (Italy), July 8-11, 2004 (available on-line at http://www.economia.uniroma2.it/conferenze/icabr2004/papers/Yiannaka.A.pdf) (showing how patentees integrate concerns about validity challenges into their own decision-making ex ante).

512 See Anderson \& Hill, supra note 271, at 443 (showing how less centralization in the definition and enforcement property rights helps to improve efficiency by avoiding rent dissipation).

513 See Kieff supra note 473 (discussing shifts in positive law).

514 The increase in small and medium sized firms, which is unique to the U.S., after the addition of patents in the U.S., is consistent with the antimonopoly power of patents explored earlier. See supra Part III.C.3(a). 
To be sure, the patent regime is not without problems. Indeed, several recent areas of patent law provide comparatively poorer mixes of cost and benefit. For example, overhaul to the statutory regime governing the interaction between patent law and Food and Drug law called the Hatch-Waxman Act $^{515}$ raises a host of public choice, administrative, and market power problems. ${ }^{516}$ Also, the uncertainty governing the process of patent claim construction may be frustrating the patent system's important ex ante incentives for private ordering by both patentees and infringers. ${ }^{517}$ In addition, the increasing reliance in infringement matters on the doctrine of equivalents is similarly frustrating the patent system's important ex ante incentives for private ordering by both patentees and infringers. ${ }^{518}$ Lastly, the recent trend by the Federal Trade Commission and Department of Justice Antitrust Division to pursue actions against patentees on so-called "upstream" technologies in the name of mitigating problems of market power, transaction costs, and anticommons problems, are actually evidence of agency capture that can not only frustrate market entry but also upsets private ordering overall, as all players in the market realize over time that terms like "upstream" and "downstream" are so relative that they simply may be synonyms for "things to be bought" and "things to be sold" by any private party able to gain the agency's attention. ${ }^{519}$ But each of these bodies of contemporary patent law

515 Drug Price Competition and Patent Term Restoration Act (Public Law 98-417, 98 Stat. 1585 (1984), codified at 21 U.S.C. $\$ 355$ and 35 U.S.C. $156 \& 271$.

516 See, e.g., FTC report entitled "Generic Drug Entry Prior to Patent Expiration" (July 2002) (describing problems with Hatch-Waxman Act and collecting sources).

517 For an excellent collection of recent empirical work on claim construction by R. Polk Wagner, see www.claimconstruction.com. Importantly, the uncertainty here is not the individualized uncertainty associated with what some see as high reversal rates on appeal but rather the lack of coherence, or predictability, that the entire body of claim construction law seems to be generating. Ironically, the empirical work by Wagner suggests that although the body of legal rubrics that are available for claim construction may not yield predictability, simply knowing the identities of the members of the appellate panel at the Federal Circuit may yield at least case specific predictability at the time of oral argument.

518 The point here is that patentees may be able to gain more flexibility in claim scope while at the same time providing more certainty to infringers by relying on the established disclosure rules of Section 112 than on the doctrine of equivalents. See Kieff supra note 14, at 8-9 (discussing Warner-Jenkinson Co., Inc. v. Hilton Davis Chemical Co., 520 U.S. 1153, 117 S.Ct. 1352 (1997) (holding that patent claims that are not infringed literally may still be infringed under the judge-made rule called the "doctrine of equivalents" to allow patentees flexibility) and Festo Corp. v. Shoketsu Kinzoku Kogyo Kabushiki Co., Ltd., 535 U.S. 722, 122 S.Ct. 1831 (2002) (holding that the doctrine of equivalents is cabined by the judge-made rule called "prosecution history estoppel" to allow third parties more certainty in knowing what will infringe a patent)).

519 For an excellent and easily accessible review of such recent FTC activities see Stanley M. Gorinson, James L. Ewing, IV, and Peter M. Boyle, Federal Antitrust Enforcers Focus on Intellectual Property Abuses, InTEllectual Property LAW TODAY 38 (Aug. 2003) (discussing Rambus and Unocal cases). For more detailed discussion of the theoretical underpinnings of the problem with these actions see Kieff \& Paredes supra note 427. 
could, and should, be reversed, through case or statute, as appropriate; and indeed none was provided for in the institutional framework of the 1952 Patent Act, itself. Put differently, the patent system of yesterday may be better in several respects than the patent system of today.

As also explored in earlier work by the present author, the positive law rules for enforcing and obtaining trademarks are also effective and efficient in achieving coordination benefits while minimizing social costs. ${ }^{520}$ Coordination is needed for the symbols protected by trademarks because the commercialization of these symbols is also a costly, risky, and complex process in which second-mover advantages can dominate and which requires many diverse actors besides the one first making appropriate use of the symbol in commerce, including for example, capitalists, business partners, and advertisers. ${ }^{521}$

The rules for enforcing and determining validity of trademarks facilitate ex ante private ordering because, as with patents, they turn on facts equally knowable to all market actors in advance. ${ }^{522}$ Also as with patents, the rules allowing the trademark holder to elect to sue or license anyone who would be guilty of direct, contributory, or induced infringement are important in ensuring that use of the protected subject matter is pushed towards fully competitive levels. $^{523}$ In addition, as with patents, the validity and disclosure rules of trademark help protect third party investments, both ex ante, and ex post. For example, ex ante investments are protected through rule giving a cause of action to a prior user of a mark that is made famous by a subsequent user. ${ }^{524}$ Similarly, ex post investments are protected by the limited scope of trademark rights in the first instance by, for example, the doctrine that prevents trademark rights from

520 Kieff supra note 8 at 751-754 (exploring law and economics of positive law rules for obtaining and enforcing trademarks and their role in commercialization).

521 Id.

522 Key evidence typically takes the form of survey data from ordinary customers

523 Because the need to make commercial use of the subject matter protected by trademarks is less compelling than for patents - because functionality is a bar to trademark protection - the impact of any remaining distortion caused by market power is less severe. That is, there is still the potential for static economic dead weight loss, but the alternative moral claims about output effects are mitigated.

524 See, e.g., Big O Tire Dealers, Inc. v. Goodyear Tire \& Rubber Co., 561 F.2d 1365 (10th Cir. 1977) (protecting small prior user's mark using theory sometimes called "reverse confusion" because the public is lead to confuse the first-user's mark with the more famous second-user's mark and think that the first is the second rather than the more typical confusion case in which a second user's mark is confused with that of a first user). In some cases, both users may be allowed to operate in different markets. See, e.g., Burger King of Florida, Inc. v. Hoots, 403 F.2d 904 (7th Cir.1968) (holding that the national chain Burger King is allowed exclusive use the mark throughout the nation except in the town of Matoon, IL, where a prior user in that particular location is allowed to continue exclusive use). 
covering functional elements. ${ }^{525}$ And as with patents, the contours of the rights staked out by trademarks are largely set by the rights-holders themselves, which mitigates the rent dissipation that otherwise can accompany the establishment of property rights. 526

While the trademark system generally works well in facilitating coordination over non-functional aspects of products and services, several recent changes in trademark law have eroded this function in important ways. Consider for example, the recent Dastar decision to substantially limit false advertising claims as a matter of law when they touch on subject matter that relates to other IP regimes, ${ }^{527}$ as well as the recent Moseley decision to limit dilution causes of action to cases of actual dilution rather than also including likelihood of dilution. ${ }^{528}$

The approach the Court took in Dastar runs the risk of eviscerating as a matter of judge-made law the carefully crafted balance struck by the legal institutional framework set forth in the Lanham Act. ${ }^{529}$ The Court's approach interferes with private ordering by both producers (who can no longer bring causes of action that are important for coordination) and by consumers (who lose the benefit of truthful advertising for planning and making purchase decisions). ${ }^{530}$

The approach the Court took in Moseley also runs the risk of eviscerating as a matter of judge-made law the carefully crafted balance struck by the legal institutional framework associated with the Lanham Act. ${ }^{531}$ Limiting causes of action for dilution to cases in which actual dilution has occurred may eliminate

525 See, e.g., In re Morton-Norwich Products, Inc., 671 F.2d 1332, 1339 (C.C.P.A. 1982) (Rich, J.) (reviewing functionality doctrine and collecting sources).

526 See Anderson \& Hill, supra note 271, at 443 (showing how less centralization in the definition and enforcement property rights helps to improve efficiency by avoiding rent dissipation).

527 See Kieff supra note 14, at 1722-26 (discussing Dastar decision).

528 Moseley v. V Secret Catalogue, Inc., 123 S. Ct. 115 (2003) (interpreting statute to be limited to causes of action for only actual dilution, not likelihood of dilution, which is in contrast to the causes of action available for confusion that include both those for likelihood of confusion and actual confusion).

529 See Kieff supra note 14, at 1722-26. More recently, Laura Heymann has provided an excellent and detailed treatment of the importance of allowing trademark-type false advertising causes of action relating to potentially copyrighted works. See Laura A. Heymann, The Birth of the Authornym: Authorship, Pseudonymity, and Trademark Law, The George Washington University Law School Public Law and Legal Theory Working Paper No. 101, forthcoming at 80 Notre DAME L. REV. _ (2005).

530 Id.

531 Although not expressly set forth in the statute itself, dilution was very much part of the institution of trademark law associated with the Lanham Act. Compare Sara Stadler Nelson, The Wages of Ubiquity in Trademark Law, 88 IOWA L. REV. 731 (2003) (criticizing the long persistence of dilution in the institution of trademark law since just before the framing of the Lanham Act). 
the effectiveness of the cause of action for dilution. Eliminating dilution would frustrate the coordination benefits of trademarks by providing marginally decreased protection for exactly those marks around which coordination and commercialization were marginally most successful. ${ }^{532}$ Protecting these marks in this way recognizes that individuals sometimes are motivated to buy simply by fashion concerns - such as to appear a certain way, to appear to be motivated in a certain way - rather than by concerns about source of a particular good or service. ${ }^{533}$ That is, availability of a dilution cause of action makes it profitable for firms to invest in making marks fashion statements in their own right. ${ }^{534}$ In turn, these marks offer consumers the opportunity to make the ultimate consumption choice - to buy with frivolity what simply is desired but not needed. ${ }^{535}$

As there is no suggestion in the Court's opinions or elsewhere that Congress lacks sufficient power to promulgate a statute that could be worded slightly differently so as effectively to overrule both Dastar and Moseley, coordination concerns suggest such an effort may be well worth perusing. Indeed, it would bring these two areas of trademark law back into conformity with the

532 See Kieff supra note 8, at 752-53. As pointed out by Judges Rich and Nies, two leading scholars of both the history and theory of trademark law, there is not and should not be any principle of trademark law that requires imposition of a penalty for the originality, creativeness, attractiveness, uniqueness, or even fame of one's product. In re DC Comics, Inc., 689 F.2d 1042, 1046-55 (Fed. Cir. 1982) (opinions of Judge Rich and Judge Nies concurring separately in result). They note that the opposite rule

has led courts to an esoteric and extraneous inquiry focusing on what motivates the purchasing public to buy particular goods, the product itself or the source. . .

. The reason the public is motivated to buy the product . . . is of concern to market researchers but is legally immaterial to the issue of whether a particular designation is generic.... It would be unfortunate were we to discourage use of a spark of originality which would transform an ordinary product into one of grace.

Id.

533 See supra note 91 (discussing fashion).

534 See Kieff, Commercializing Inventions, supra note 8, at 752-53 (noting that "the amount of investing in potentially famous marks will rise" and citing William M. Landes \& Richard A. Posner, The Economics of Trademark Law, 78 TRADEMARK REP. 267, 304 (1988)).

535 Id., at 753. To be sure, it is recognized that the consumers might argue that because their collective attention in the mark is at least as responsible for the mark's fashion status, the mark should be owned by them, not the one commercializing the mark. Id., (citing Jessica Litman, Breakfast with Batman: The Public Interest in the Advertising Age, 108 YALE L.J. 1687, 1730). The commercialization theory, however, explains that it makes sense to treat the mark as private property owned by the one who engaged in commercialization because such treatment facilitates the coordination necessary to promote the mark to this level of recognition. Nevertheless, it also is recognized that investments of this type - by both producers and consumers - have their own opportunity costs. See, e.g., Michael Abramowicz, Copyright Redundancy, supra note 303 (pointing out in the context of copyrights that there may be too much investment of this type). 
institutional framework associated with the Lanham Act as framed. ${ }^{536}$ Such changes would also further the coordination goals of the system. Put differently, as with the patent system, the trademark system of yesterday may be better in several respects than the trademark system of today.

In contrast to patents and trademarks, the basic statutory scheme for copyrights grew out of a classic public choice bargain among large interest groups. These groups have regularly returned to the legislative process to reshape the framework and reach new compromises each time technology or other factors sufficiently have changed the interests of those groups. ${ }^{537}$ While such an approach does do a reasonable job integrating into the statute many of the collective preferences of those present in the negotiations at that time, it does less well integrating concerns of others, or even of the same parties at later times. ${ }^{538}$

More specifically, as the basic economics of the drafting constituencies' businesses change over time due to changing technologies, norms, etc., it should not be surprising that each iteration of the legislative bargain often will be too intensely focused on responding to prior allocations. That is, there is a lag between the change in technology and the change in economics and a subsequent

536 For a review of the history of the institution of trademark law associated with the Lanham Act, see, e.g., Thomas D. Drescher, The Transformation and Evolution of Trademarks--From Signals to Symbols to Myth, 82 TRADEMARK REP. 301 (1992); Daniel M. McClure, Trademarks and Unfair Competition: A Critical History of Legal Thought, 69 TRADEMARK REP. 305 (1979); and Benjamin G. Paster, Trademarks--Their Early History, 59 TRADEMARK REP. 551 (1969).

537 See generally, Jessica Litman, Digital Copyright, 23, 135-63 (2001) (reviewing "unique" public choice history of copyright and explaining how since 1909 all but two of the frequent revisions to copyright law were essentially written by collective bargaining among some of the impacted industries and citing the following as the only two exceptions: (1) The Computer Software Copyright Act of 1980, Sec. 10, Pub. L. No. 96-517, 94 Stat. 3015, which revised Section 117 to expressly extend copyright protection to computer programs on the recommendation of the Commission on New Technological Uses of Copyrighted Works (CONTU), a committee of experts focused on copyrights in computer software; and (2) The Fairness in Music Licensing Act of 1998, Sonny Bono Copyright Term Extension Act, Pub. L. 105-298, 112 Stat. 2827, which amended Section 110(5) to limit the number of institutions required to pay performance royalties for nondramatic musical works)). See also, Niels Schaumann, Intellectual Property Symposium: The Impact of the United States Supreme Court on Intellectual Property This Millennium, 30 WM. MitCHELL L. REV. 1617, 1619, n.8 (citing same two exceptions). Even these two revisions that putatively did not emerge directly from interest group pressures may themselves have been driven by concerns for interest groups. For example, I thank Mike Meurer for pointing out the interest Congress may have had in appearing to be sensitive to the needs of small restaurants and coffee shops when passing The Fairness in Music Licensing Act of 1998. See also, David Nimmer, Codifying Copyright Comprehensibly, 51 UCLA L. REV. 1233, 1281 (arguing that the statute "smacks of special interest legislation for the benefit of a defined class").

538 In part this is a race to the bottom story and so does not argue that such a process will always yield this bad result but rather it explains how one contributing factor may have played a role in this case. 
lag between the change in economics and efforts to renegotiate the legislative bargain. This is an important difference between the drafting approach used for the patent and trademark regimes on the one hand and the copyright regime on the other and this difference leads to comparatively greater public choice costs for the copyright regime as well as comparatively less ex ante coordination benefit.

But more important than this historical explanation for how the copyright regime came to fare comparatively less well than the patent and trademark regimes, a comparative institutional economic analysis of the regimes themselves shows why the copyright regime does fare less well. On this measure, as described more fully below, copyright is less successful in achieving coordination benefit because it is too clumsy in operation. What is more, the copyright regime may not be needed to achieve coordination benefits in the first place, at least for the entertainment industry. Put differently, the copyright regime may seen as resembling a bridge over a river that is not only redundant of other crossings, but that also has essentially collapsed under its own weight.

Copyright is famously difficult to understand, even for business actors within the system. ${ }^{539}$ Even though copyright involves assets over which private parties are more informed than government actors (and so property rules dominate liability rules $)^{540}$ the system employs a host of liability rules, as well as exceptions to infringement (such as fair use and home recording for self use and for distribution to friends and family) and exceptions to those exceptions (such as the Napster case holding liability for sharing with peers where done over the internet). ${ }^{541}$

In addition, evolved rules on preemption and misuse leave property owners unclear as to what coordinating deals can be struck. ${ }^{542}$ That is, taking the strong form of the preemption arguments at face value would suggest that efforts to sell songs through services like i-Tunes under contracts limiting subsequent distribution may be trying to impose acceptance of restrictive contract terms that are as a matter of law preempted and therefore void as against public policy. ${ }^{54}$ Then, taking the strong form of the misuse arguments at face value such an effort

539 According to Rob Glaser, Chairman of the company MusicNet, "It's as if Franz Kafka designed this system and employed Rube Goldberg as is architect." Amy Harmon, Copyright Hurdles Confront Selling of Music on the Internet, N.Y. TIMES, Sept. 23, 2002, at C1.

540 See supra notes 328-344, and accompanying text (discussing relative roles of property rules and liability rules).

541 Consider compulsory licensing at positive rates in many areas like re-transmissions (Sections 114, 115, 116, 118, 119, 122) and jukeboxes (Section 116). Also consider compulsory licensing for free for those uses determined to be fair (Section 107 on Fair Use and Section 122 on copies for the blind).

542 See Kieff supra note 14, at 5-7 (discussing preemption); Kieff \& Paredes supra note 427 (discussing misuse).

543 See Kieff supra note 14 , at 5-7 (discussing preemption). 
to impose illegal terms in a contract over material that relates to copyright would constitute misuse of a type that would at a minimum make any otherwise valid IP rights involved in the transaction unenforceable and at a maximum subject the one imposing the contract terms to antitrust liability including, potentially, treble damages and attorney fees. ${ }^{54}$

Even the rules on validity and scope of copyright itself are comparatively murky. ${ }^{545}$ What is more, unlike for patents and trademarks, they essentially are set as immutable rules (not even default rules) through the central regime rather than by the individual claimants, and therefore are most likely to be associated with rent-dissipation. ${ }^{546}$

The mere fact that cases like Napster and Aimster were brought is evidence that the regime simply is failing to allow sufficient private ordering to occur to meet new customer needs. ${ }^{547}$ Cases like this can be seen as evidence of large numbers of consumers manifesting some willingness to pay some positive price by going through the hassle costs of participating in the services but electing instead to pay no monetary price because no effective sales venue was provided. Put differently, these cases can be seen as evidence of producers being motivated not to sell in these markets at least in part by the fear that such business models would not be afforded legal protection, and instead might generate legal liability under doctrines of misuse or antitrust. ${ }^{548}$ Indeed, for some time the fear of rampant copying by consumers has driven producers to seek and obtain statutory changes providing criminal liability for copyright infringement in certain circumstances. The fear of this criminal liability imposes an added cost on consumers.

544 See Kieff \& Paredes supra note 427 (discussing misuse).

545 Consider, for example, the murky rules about what constitutes a derivative work or an adaptation. Also consider the basic question of whether putative copyright subject matter is protectable expression or unprotectable idea. On the difficulty with the so-called idea/expression dichotomy, see Gregory Aharonian, Problems with Copyright and Trade Dress, available on-line at http://www.patenting-art.com/copyprob/cpyqst-e.htm (quoting F. Scott Kieff at the conferences "Promoting Markets in Creativity: Copyright in the Internet Age" held June 10, 2003 in Washington, D.C. ("The 'idea/expression' dichotomy is so ill-defined that lawyers have no idea how to express it")).

546 See supra notes 512 \& 526, and accompanying text (similarities in approaches for patents and trademarks).

547 See A \& M Records, Inc. v. Napster, Inc., 239 F.3d 1004, 1020 (9 ${ }^{\text {th }}$ Cir. 2001) (suit against service that facilitated peer to peer sharing of copyrighted music); In re: Aimster Copyright Litigation, 334 F.3d 643 ( $7^{\text {th }}$ Cir. 2003) (same).

548 To be sure, other motivations such as fear of copying also operate here. Therefore, an important area of further research would include a determination of which motivations are operating and to what extent, such as through the gathering of empirical evidence of legal positions explored by players in this industry. Gathering such data is likely to face several obstacles, however, because it seeks to elucidate information that would be both protected by the attorney-client privilege and potentially very damaging. 
At bottom, the uncertainty, coordination, administrative, and public choice costs associated with the copyright system may be operating to frustrate its ability to facilitating coordination through private ordering. At the same time, these same features of the regime impose remarkably high costs on both consumers and producers. For producers, costs include the risk of antitrust liability. For consumers, costs include the inability to gain access to copyrighted works as well as the threat of criminal sanction.

\section{B. Beginning the Case against Copyright}

There are several important differences between the institutional economics of the patent and trademark regimes on the one hand and the copyright regime on the other. While the patent and trademark regimes achieve coordination benefit with low social cost, as designed, the copyright system has grown largely out of collective bargaining as a descriptive matter while being motivated by reward theories as a normative matter. The present copyright regime does reward many of the constituencies present in the legislative bargaining, but it fails to achieve effective coordination because of excessive uncertainty and regulation. The basic differences between the approach of patents and trademarks on the one hand and copyrights on the other hand, suggest the possibility that the types of coordination needed for at least the entertainment industry may be facilitated sufficiently without a copyright regime at all, as long as well functioning trademark and patent regimes are present.

Key to the proposed model industrial organization system for the entertainment industry, such as publishing, film, and television, is the realization that commercialization costs today in the entertainment industry are largely those associated with advertising, reputation, and business networks. Due to technological changes, physical plant costs of distributing in this industry need not be as large as before. ${ }^{549}$ Yet, as discussed earlier, trademark law works well to allow some coordination and some pricing above marginal cost of the type necessary to facilitate commercialization of goods and services facing such reputation and network costs. Thus, as discussed below, a model approach might be suggested under which the industry would rely essentially on trademarks (and to some extant patents) rather than copyrights. Put differently, the model begins the conversation of a modest proposal: ${ }^{550}$ for the entertainment industry to reply trademarks and patents instead of copyrights.

549 An internet server of sufficient bandwidth will be sufficient if advertising and other network costs have been effectively deployed.

550 It is recognized that the proposal is more extreme than modest, just as was Jonathan Swift's "modest proposal" that the problems of Irish poverty be solved through the sale of Irish babies as food for the wealthy English, JonATHAn SwIFT, A Modest Proposal, in GulLiVER's Travels And Other Writings 439, 441 (L. Landa ed. 1960). A less extreme proposal is Marie 
Implementing effective coordination in the entertainment industry absent copyright may be conceivable. First, major advances in these industries, although likely rare, would be eligible for patent protection (a new projector, a new chord, etc). ${ }^{551}$ Second, while non-commercial infringements may not be actionable under trademark law, ${ }^{552}$ content providers can adapt to nevertheless make coordination and commercialization profitable against the backdrop of effective trademark protections. For example, trademark suits would be viable against commercial infringers. To the extent needed, these rights can be strengthened by re-instating dilution law, or by reversing Moseley. ${ }^{553}$

Content providers may be able to take several different steps that in concert with consumer prescriptive norms and preferences may yield a landscape of descriptive norms in which coordination and commercialization are profitable. First, as Demsetz pointed out, private producers can produce public goods efficiently given the ability to exclude non-purchasers, and price discrimination is consistent with competitive equilibrium for such public goods. ${ }^{554}$ That is, content providers can establish networks that sell, or even give away, content along with other bundled goods and services, such as updates, ${ }^{555}$ replacements, library management tools and services, etc. ${ }^{556}$ By effectively educating consumers on such practical, commercial, benefits of purchasing through licensed sources, content providers may be able to maintain profitable networks. Indeed, further strengthening of the content provider's position - and further protection of consumers - may be obtained by reversing Dastar's elimination of certain false advertising suits. ${ }^{557}$

Antoinette's "let them eat cake" remark offered in response to inability for the impoverished population in France to afford even bread.

Legend has it that as the people were rioting in the streets in Paris just before the French Revolution, Marie Antoinette turned to her assistant and asked, "What is wrong? Why are the people fighting in the streets?" "They have no bread to eat, your majesty" came the response. "No bread?" gasped Marie. "Let them eat cake."

Molly Townes O'Brien, Questioning the Power of Consumerism to Reform Public Education, 75 ST. JOHN'S L. REV. 233, n.1 (2001) (“The story is said to have originated with Jean Jacques Rousseau in his Confessions, Book 6 (1782) and is generally understood to be fictional.").

551 See CHISUM, ET AL. supra note 5, at 728-828 (discussing statutory subject matter).

552 That is, file sharing will still likely occur.

553 See supra note 528.

554 See Kieff supra note 8, at 727 (citing Harold Demsetz, The Private Production of Public Goods, 13 J.L. \& ECON. 293 (1970)).

555 This method is used frequently for software.

556 Apple I-tunes is one approach to selling. The Wallmart approach is more like bundling since they are (supposedly) selling below cost and so are essentially bundling with advertising in much the same way that Demsetz suggested that television signals could be bundled with advertising.

557 See supra note 527. 
Second, the role of consumer norms must not be overlooked. ${ }^{558}$ If artists and publishers make clear which works are "authorized" and therefore associated with some pay-back to the originators of the work, then the customers may be willing to pay more for those works. Again, at the very least, suits under 43(a) will be available against commercial competitors, even when there is only falsity, as opposed to confusion as to source. In much the same way that cult followings like to support their object of allegiance, general consumer norms may - at least at the right prices - be willing to pay simply to support their preferred performers and distributors. ${ }^{55}$ Indeed, much of the direct income generation that already occurs in the entertainment industry is based on marketing of products and services that are only linked to core content, a strategy known as "merchandizing." The ability to capture revenues though such tying, however, requires the availability of suits for false advertising and dilution, as well complex contractual arrangements. Importantly, transaction costs are lower when tying is done through merchandizing or through advertising (as is done with broadcast television content that is itself provided for "free" when tied to the sale of advertising time). Instead of the content provider having to transact directly with each user, the transaction can be with the tied merchandisers or advertisers.

At bottom, the analysis offered here is designed to explore a hypothetical industrial organization model under which coordination may be achieved for entertainment industry by using the regimes of trademark and perhaps patent; but not copyright. Such a model may be associated with lower social costs than the present copyright system. If so, then the participants in this industry can get more, at lower cost, by eschewing, or perhaps even jettisoning, copyright.

To be sure, the model offered here is only a model, and only of most relevance for an industry where the commercialization costs are largely those associated with advertising, reputation, and networks, such as the entertainment industry. As a result, a number of areas of further study must be considered before the model could even be tested seriously. For example, a comparative study of the relative importance of trademark and false advertising rights as compared with copyright rights to established networks in the real world would provide some insight as to the model's practical appeal.

In addition, objections to the model may include pointing out that even on its own terms it does little to address the copyright needs of low volume industries, such as sculptors and painters. While reputational effects help in those sectors, absent copyright, they may not be sufficient to drive trademark and false advertising issues, particularly with regard to the type of factual data about

558 For more on norms see supra Part II.C.1.

559 Compare, Wendy J. Gordon, Render Copyright Unto Caesar: On Taking Incentives Seriously, 71 U. CHI. L. REV. 75 (2004) (suggesting that authors may respond particularly well to reputation incentives). 
overall consumer behavior that are needed to mount a successful case using those causes of action. Nevertheless, reputational effects may be sufficient to drive other methods through which income can be extracted such as the selling of authentic signatures on mementos or authentic artifacts associated with the works of art. For example, both of these techniques have been employed by the artists Christo and Jeanne-Claude, whose works themselves - such as the wrapping of the Reichstag, which culminated in a pubic display in 1995 - are simply not able to be sold. ${ }^{560}$

Before the model could be implemented in a working legal system a number of additional obstacles would also need to be overcome. For example, as indicated in the model itself, the trademark system would need to be rolled back to the way it was before Dastar and Mosley - both false advertising and dilution would be needed. In addition, a number of administrative and public choice costs are raised by the need to determine the carve-out from copyright that the model proposes for certain industries.

Importantly, the model is not so much offered as the beginning of the end of copyright; but rather as a tool for elucidating some highlights of the differences in institutional frameworks between the major positive law IP regimes. If nothing else, it is hoped that the present study elucidates the tie between social costs and reward theories that is emblematical of the copyright system.

\section{CONCLUSION}

The complexity of modern copyright may frustrate the ability of the system to achieve the coordination benefits IP rights can deliver, and that patents and trademarks generally do deliver. This same complexity of modern copyright causes the costs of the copyright system to be remarkably high. A radical conclusion would be that the case today for copyright simply fails. A more modest conclusion would be that the comparative institutional analysis explored in this paper shows how copyright may be become more obsolete in view of patent and trademark if copyright were to become even more complex than it already is. Although it seems radical, the elimination of copyright may not be bad for the central constituents involved with modern copyright - producers and consumers. Indeed, these same market actors may find their own norms - extant or potential - may be combined with the institutions of trademark and patent, at least as they recently existed, to become both more effective and less expensive in facilitating the private ordering that is necessary for the commercialization of creative works.

\footnotetext{
560 See The Art of Christo and Jeanne-Claude, available on-line at http://www.christojeanneclaude.net/ (web site authorized by the artists).
} 
Several core lessons can be drawn from the analysis offered here. NIE teaches that the details of different institutional choices matter in that they have different implications for a large number of costs and problems. Using the lessons from NIE this paper elucidates how many of the problems that have attracted attention in the IP literature turn out to be properly viewed as inapposite, overstated, or even having implications opposite of those offered by the literature. The paper elucidates how property rights in IP can provide an important additional and middle-ground tool for optional use by individuals engaged in private ordering beyond those offered by the extreme poles of either the free, open market without them on the one hand or the hierarchy of family, firm, or government on the other hand. ${ }^{561}$ The paper also shows how IP rights must be designed to facilitate private ordering if they are to play this role effectively. That is, IP rights must operate as rights of exclusion around which coordination can take place. To do so efficiently, they must be structured to mitigate the costs of rent dissipation, information, transactions, and public choice. By elucidating how at least the patent and trademark systems of yesterday operated to achieve commercialization effectively and efficiently, the paper thereby offers an overarching normative case for IP. The paper also elucidates why institutional choices for IP regimes that have been motivated by other theories of IP have been both less effective and less efficient.

At bottom, the paper shows how the set of tools from NIE can be used to conduct comparative analyses of institutional options for IP. It is hoped the approaches offered here help frame debates over future choices for these regimes.

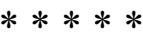

561 For elaboration on the role of property rights as a middle ground see supra notes 144146, 163-171, 173-178, and 250, and accompanying text (exploring property rights in the context of the tradeoff between market and firm). See also supra note 267(exploring property rights in the context of the tradeoff between market and government). 